\title{
Health problems and menopausal transition : a community based study
}

Citation for published version (APA):

Maartens, L. W. F. (2000). Health problems and menopausal transition : a community based study. [Doctoral Thesis, Maastricht University]. Datawyse / Universitaire Pers Maastricht. https://doi.org/10.26481/dis.20001201lm

Document status and date:

Published: 01/01/2000

DOI:

$10.26481 /$ dis.20001201lm

Document Version:

Publisher's PDF, also known as Version of record

\section{Please check the document version of this publication:}

- A submitted manuscript is the version of the article upon submission and before peer-review. There can be important differences between the submitted version and the official published version of record. People interested in the research are advised to contact the author for the final version of the publication, or visit the DOI to the publisher's website.

- The final author version and the galley proof are versions of the publication after peer review.

- The final published version features the final layout of the paper including the volume, issue and page numbers.

Link to publication

\footnotetext{
General rights rights.

- You may freely distribute the URL identifying the publication in the public portal. please follow below link for the End User Agreement:

www.umlib.nl/taverne-license

Take down policy

If you believe that this document breaches copyright please contact us at:

repository@maastrichtuniversity.nl

providing details and we will investigate your claim.
}

Copyright and moral rights for the publications made accessible in the public portal are retained by the authors and/or other copyright owners and it is a condition of accessing publications that users recognise and abide by the legal requirements associated with these

- Users may download and print one copy of any publication from the public portal for the purpose of private study or research.

- You may not further distribute the material or use it for any profit-making activity or commercial gain

If the publication is distributed under the terms of Article $25 \mathrm{fa}$ of the Dutch Copyright Act, indicated by the "Taverne" license above, 
Health problems and

menopausal transition 
- LuC W.F. Maartens, Maastricht 2000

ISBN 9052782911

Vormgeving en druk: Datawyse I Universitaire Pers Maastricht

Ontwerp omslag: Steyn Schalkx, Eindhoven

The publication of this thesis was financially supported by Astra BV. Ell Lilly Nederland BV, Glaxo BV, MSD BV. Organon Nederland BV, Pfizer BV, Solvay Duphar BV 


\title{
Health problems and menopausal transition
}

\author{
A Community based study
}

\author{
Proefschrift \\ ter verkrijging van de graad van doctor \\ aan de Universiteit van Maastricht, \\ op gezag van de Rector Magnificus, \\ Prof. Dr. A.C. Nieuwenhuijzen Kruseman, \\ Volgen het besluit van het College van Decanen, \\ in het openbaar te verdedigen \\ op vrijdag 1 december 2000 om 14.00 uur \\ door
}

Lucas Willem Frederik Maartens

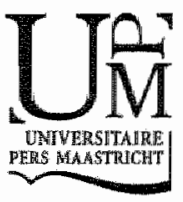




\section{Promotores}

Prof. Dr. J.A. Knotnerus

Prof. Dr. V.J. Pop (Katholieke Universiteit Brabant)

\section{Co- Promotor"}

Dr. J.J. Keyzer (Diagnostisch Centrum Eindhoven)

\section{Beoordelingscommissie}

Prof. Dr. G.G.M. Essed (voorzitter)

Prof. Dr. G.J. Dinant

Prof. Dr. P Knipschild

Prof. Dr. M. van Son (Universiteif Utrecht)

Dr. B.H.R. Wolffenbuttel 
Maturity is the time of life when, if you had the time, you'd have the time of your life.

Anonymaus 



\section{Contents}

CHAPTER 1

General introduction - 9

CHAPTER 2

Eindhoven Perimenopausal Osteoporosis 5tudy (EPOS) - 21

CHAPTER 3

Climacteric complaints in an open community - 33

CHAPTER 4

Hormone substitution during menopause:

What are we treating? -43

CHAPTER 5

Characteristics of perimenopausal women using benzodiazepines -53

CHAPTER 6

Menopausal transition and increased depressive symptomatology:

a community-based prospective study -63

CHAPTER 7

Is there a connection between autoimmune thyroid

dysfunction and depression? - 73

CHAPTER 8

General discussion -85

Summary - 97

Samenvatting - 103

Appendix - 108

Dankwoord - 126

Curriculum Vitae - 128 

General introduction 


\section{Introduction}

In Western society, women can anticipate living for approximallely 80 years [1] Therefore, when a woman reaches menopause at a median age of approximately 50 years, she can expect to live for several decades in the postmenopausal phase. It is clear from demographic data that, as the proportion of elderly women will increase over the next decades, primary health care prowiders will spend more time caring for the aging female population. There has been an increase in surveys. exploring the risk factors that lead to increased morbidity in women due to chronic diseases. Primary care providers must have a broad-based knowledge of peri-and post-menopausal health to effectively establish and implement prevention and treatment protocols within the aging female population. The transition from the reproductive phase to the postreproductive state is not as sudden an event as the term menopause would suggest [2]. A term that is frequently used to describe the entire period of transition is climacteric [3]. The climacteric can be conceptualized as changes at several levels - hormonal, menstrual, vasomotor symptoms and psychologicall reactions to menopausal transition with marked variation between women in their experience of the menopause $[4]$. It is assumed that menopause is accompanied (to a greater or lesser extent) by hot flushes, sweating, prolonged menstrual irregularities, vaginal dryness, and a range of other symptoms, including irritability, insomnia, dizziness, arthralgila, lack of self confidence, and depressed mood [5-9]. These assumptions are perpetuated by the use of menopausal checklists that ask women retrospectively to report the symptoms they experience during menopause. Until relatively recently, the term "menopausal syndrome" was used to refer to a wide range of physical and emotional symptoms, presumed to be caused by hormonal changes. The term appeared to be over-inclusive and, despite extensive evidence showing that, as such, it does not exist [10] in the popular and medical literature menopausal women are still frequently considered as suffering from a considerable array of problems 111 .

General practitioners in particular are confronted daily with this rather extensive range of variable and often vague complaints of women going through the early stages of menopause $[12 * 13]$. In the Eindhoven Perimenopausal Osteoporosis 5 tudy (EPOS) [14], in view of the extensive pattern of complaints that are rather difficult to pinpoint, we have attempted to establish which complaints are specifically menopause-related, and moreover, have tried to find an explanation for the variety of other complaints that are often presented. Especially, we were interessed in the apparent similarity to complaints often presented in cases of depression, as well as to the symptoms of hypothyroidism. Over the past few years, the interest shown in the causality and consequences of the symptomatology of "depression" has grown explosively. Because the prevalence of depression is demonstrably high $6 \%$, which, in the Netherlands, amounts to 800,000 patients per year), with many undiagnosed depressive patients running 
the risk of becoming medicalized, the burden of depression is considerable [15-18]. In addition in earlier studies, a relationship between depression and hypothyroidism has been suggested [19] These considerations have led to the initation of a community-based study on the problems that exist or emerge during the early stages of menopause.

\section{Community based surveys}

In the 1970s and 1980s, several cross-sectional studies in community based samples of middle-aged women were conducted, which suggested that only vasomotor symptoms were clearly associated with the menopause [20-21]. Reports on menopausal symptoms have repeatedly indicated that the significance of menopause varies per culture, and therefore also the pattern of complaints [4]. In Japan, hot flushes are much less frequently reported than in Western countries; there is not even a word for this in Japanese. In Indlia, there is no evidence of a climacteric syndrome among women from the higher castes. Indeed, as soon as these women stop menstruating. they are freed from all kinds of social restrictions, and their status improves [22].

In the Netherlands, the first community-based surveys date back more than 30 years. In 1967, 1977 and 1987, large cross-sectional studies were conducted in Ede by, respectively, Jaszmann [23], Brand [24], and Oldenhave [5]. Oldenhave showed an association between the severity of vasomotor complaints and menstrual complaints on the one hand, and more atypical complaints, such as insomnia, tiredness, and 'lack of well-being', on the other.

In a review of the literature Groeneveld [25] found a significant association between vasomotor symptoms and/or vaginal dryness, and the menopausal phase. He found no relationship between hormonal levels and the severity of climacteric symptoms. However, he did show that psychosocial factors have more influence on the occurrence of symptoms and complaints than the menopause as such.

\section{Context Eindhoven Perimenopausal Osteoporosis Study}

During the 1990s, the epidemiological insight into the long-term effects of oestrogen deficiency increased considerably. Due to this, osteoporosis received much more attention, and the appearance of the DEXA meter (dual energy X-ray absorbtiometry) made it possible to accurately measure bone mineral density (BMD) in a reproducible manner, with minimal radiation [26-31]. Not only the effect of medication on BMD, but also the influence of food and life style (alcohol, nicotine, exercise, exposure to daylight, etc.) could therefore be better monitored 
[32-33]. The prediction of a world-wide osteoporosis epidemic resulted in a huge increase of studies on the causes and implications of osteoporosis, and in the development of medication to prevent fractures. This was the context in 1994 of the Eindhoven Perimenopausal Osteoporosis Study (EPOS) [14], aiming at and providing an answer to the question: what is the prevalence of low bone mineral density, and how helpful is the screening of perimenopausal women for decreased BMD? The EPOS study not only included DEXA measurement of all the participants, but also biometry, blood samples, and questionnaires that had to be completed and returned within a week. Follow up data have been collected in 1996 and 1998. Between September 1994 and September 1995; all women borm between 1941 and 1947 (n=8503) who were living in the city of Eindhoven, The Netherlands, were invited to participate in the study by the Diagnostic Centre Eindhoven (DCE), a diagnostic centre for general practitioners, and the Department of Municipal Public Health Services, Eindhoven. Of the 8503 women, 8098 of whom were Dutch, $6846(81 \%)$ responded to the invitation and $6648(78 \%)$ agreed to participate in the study. The willingness among this perimenopausal group of women to repeatedly answer questions on the most diverse subjects was remarkable. These questionnaires provided us with an array of detailed information, among other things on menopausal complaints, depressive symptomatology, complaints associated with thyroid dysfunction, major life events, life style, medical and more specific gynaecological history, menstrual pattern, family anamnesis, use of medicines, and demographic data such as marital status, work situation, level of education, and family situation. By means of these data we attempted to answer the following questions.

\section{Questions}

General practitioners are regularly faced with patients who have to contend with perimenopausal / climacteric problems. As a result of significant physical changes (for example, with regard to hormonal balance and BMD), many troublesome symptoms are described, of which it is not always clear in how far they are specifically related to the menopausal transition [34-40]. This dissertation aims to provide a picture of the subjective and objective health situation in a population-based sample of Dutch Caucasian perimenopausal women. In particular, it focuses on the prevention and determinants of health problems with a heavy burden of illness, such as, osteoporosis, depression, hypothyroidism, troublesome subjective complaints often considered to be climacteric, and the use of medication. The goals and questions of this study are specified as follows:

1. What is the prevalence of osteoporosis and osteopenia in women around the menopause, and what are the most important determinants of low bone mineral density (BMD)? 
2. Are there differences in the occurence of (the intensity of) menopausal complaints known from the literature, when comparing the three dimacteric phases to be distinguished: pre-, peri-, and post-menopausal phase.

3. Can an association be found between the diverse and often vague complaints noted around the menopause and the declining levels of oestrogen, and what is the relation with estrogen use. Is there an overlap between menopausal complaints and depressive symptomatology?

4. Are benzodiazepines used for specific complaints during the climacteric, what are the characteristics of these users, and what are the determinants influencing the use of benzodiazepines?

5. Is there an association between depressive symptomatology and the transition from pre- to peri- and post-menopause, and what is the influence of other determinants?

6. Depression may be provoked by underlying overt hypothyroidism [44-46]. The occurrence of stressful life events (an important determinant of depression) is a risk factor for the development of thyroid dysfunction [42-43]. Is there an association between depression and autoimmune thyroid dysfunction?

\section{Methods}

In chapter 2 BMD was measured by Dual X-ray Absorptiometry (DEXA). Evaluation and measurement were performed at two centres: the Diagnostic Centre Eindhoven (Hologic DXA model QDR-1000 S/N291) and the St Joseph Hospital, Veldhoven (Hologic DXA model QDR-2000 S/N2260).

In chapter 3 menopausal complaints were assessed using a validated selfrating questionnaire covering 24 items. After literature research we added three items: vaginal dryness, pain during intercourse and waking at night. The severity of the complaints was indicated on a four-point scale: absent, slight, moderate and severe. In order to compare the complaints, they were divided into absent $(=0)$ and present (slight/moderate/severe) $(=1)$. First the chi-square test for independent samples was carried out to compare the frequency of occurrence of the complaints in the three categories of climacteric status using a two sided significance level of $p<0.05$. The complaints that showed differences at a univariate level with a $p$-value $<0.1$, were entered into a multiple logistic regression analysis in order to obtain adjusted odds ratios (with 95\% confidence intervals) for the relationship between climacteric status (dependent variable) and complaints (independent variables) during the menopausal transition.

In chapter 4 depressive symptoms were assessed using the Edinburgh Depression Scale (EDS), a 10 item self-rating scale (range of sum-score 0-30 with higher scores indicating more depressive symptomatology) with a commonly used cut-off score of $>12$ for minor depression and $>14$ for major depression. The EDS has 
been validated for middle-aged, mon-childbearing women. The scale shows appropriate psychometric characteristics: a predictive value of $71 \%$, a sensitivity of $68 \%$, and a specificity of $92 \%$.

The occurrence of menopausal complaints was assessed using the 27-item self-rating scale which has been used in chapter 3 already. The psychometric properties of this 27 -item self-rating scale were analysed in the women not using any hormonal substitution ( $n=2332$ ). Principal Compound Factor Analysis showed that 22 items loaded significantly and covered three sub-scales (Table 1): a wasomotor sub-scale ( 3 items: flushing, day sweating, night sweating, range 0-9), an uro-genital sub-scale (4 items:Vaginal dryness, pain with cohabitation, vaginal itching and burning on micturation, range 0-12) and a cognitive / vegetative sub-scale (15 items: Irritability, lack of energy, depressed mood, lack of self confidence, agitation, forgetfulness, tiredness on waking, headache, tiredness, dizzyness, muscle pain, shortness of breath, restless legs, palpitations and insomnia. range $0-45$ ) with a Cronbach's Alpha of $0.90,0.88$, and 0.65 , respectively reflecting adequate internal consistency. Correlations between the various scales were analysed by means of Pearson's correlation coefficient (using two-tailed p-values) (Table 2).

ANOVA was used to analyse the differences in mean scores on the three subscales of menopausal complaints between three different groups: women using hormone replacement therapy (HRT), women using oral contraceptives $(O C)$, and women not using oestrogens or progestagens. In order to detect differences between these groups a post hoc analysis was performed using the Scheffe procedure.

In Chapter 5, menopausal complaints were assessed by using the 27 -item self-rating questionnaire with a four-point score per item $10-3$, range of sum score 0-81), with a cut-off score of 50 being one standard deviation above the mean. Differences in proportions were tested with the chi-square test for independent samples The $t$ test was performed to assess the differences in EDS score and menopausal complaints between BZD users and non-users.

In Chapter 6 depression was assessed using the EDS score. The change in EDS score between two consecutive moments $T 1$ and T2 was evaluated using paired samples t tests (wo-tailed). Subsequently, the independent rellationship between menopausal transition (independent variable) and the intra-individual change in EDS score (dependent variable) was analysed by multiple logistic regression.

In Chapter 7 depression was assessed, as in the other surveys, using the EDS scores. Thyroid function was assessed by the measurement of free T4, TSH and thyroximemperoxidase antibodies (TPO $\mathrm{Ab}$ ). 


\begin{tabular}{|c|c|c|c|}
\hline 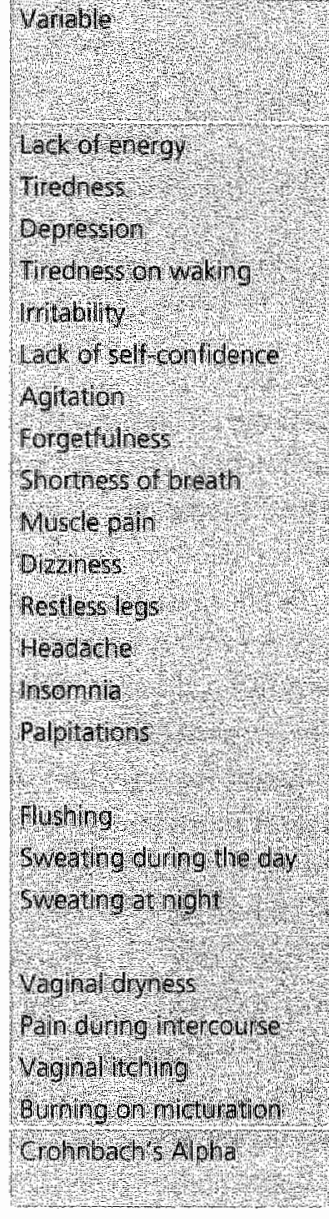 & 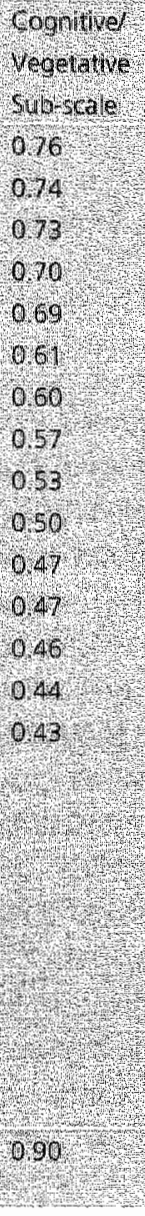 & 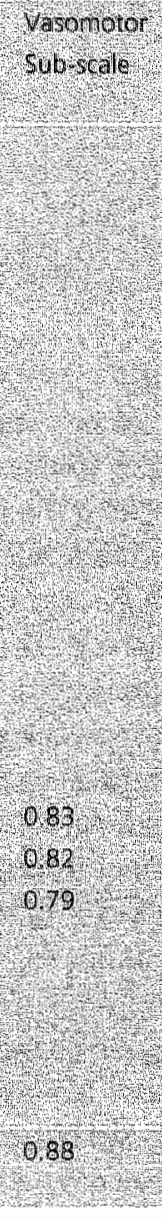 & 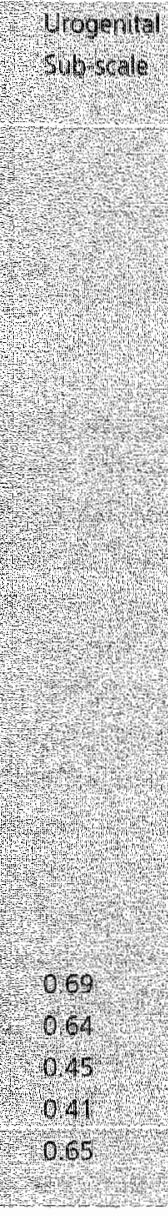 \\
\hline
\end{tabular}

\section{Structure of this Thesis}

In Chapter 2, the design of the EPOS study is explained in detail. This part of EPOS specifically focuses on measuring BMD in the population, on the relationship with age and menopausal state, and on a number of other determinants. It is aimed in particular at identifying that group of women at high risk of developing osteoporosis, who might therefore be candidates for intervention.

Chapter 3 deals with menopausal complaints. On the basis of a 27 -item questionnaire, we investigated whether menopausal complaints and the menstrual pattern during the early years of menopause are associated. Typical menopausal complaints, such as vasomotor complaints and urogenital complaints, are often treated with hormone replacement therapy (HRT). Many other complaints (cogni- 


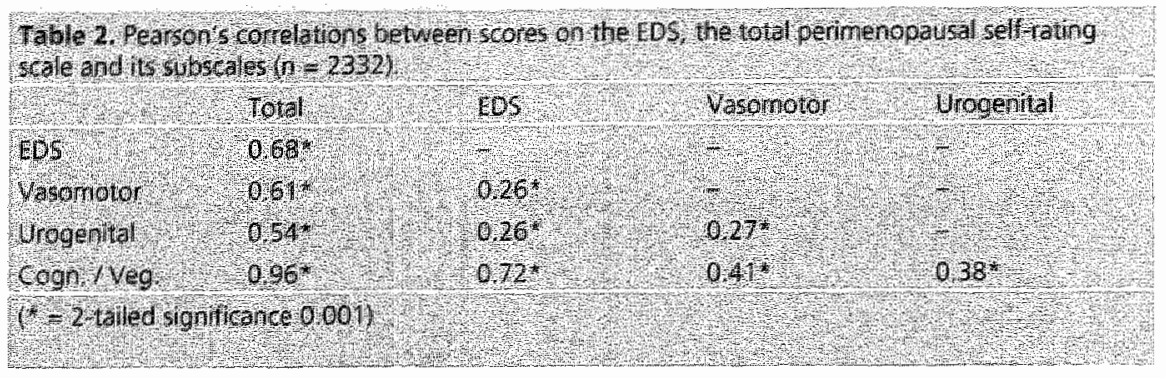

tive/vegetative) that are seen around the menopause are also frequently attributed to the menopause, and are therefore treated with HRT. Therefore, in Chapter 5 , we have investigated the relation between HRT use and menopausal complaints and, for this purpose, have compared three groups, not using hormones, using oral contraceptives, and using HRT, respectively, in relation to the menopausal complaints presented. Because we found the presence of depression to be an important determinant in the presentation of (menopausal) complaints, and because a relation between benzodiazepines and the presentation of, in particular, cognitive/vegetative complaints is suggested in literature, in Chapter 6. we have investigated the relationship between menopausal complaints, a score on the Edimburgh Depression Scale (EDS), and the use of benzodiazepines. Contrary to all opinions expressed in the existing literature [41], the findings in this chapter were reason enough to reinvestigate in a longitudinal study, in Chapter 7 , a possible intra-individual relationship between passing through different menopausal phases and a change in depressive symptomatology. Because it was documented that major life events are independent risk factors for the existence of a high EDS score, and it is also known that stressful life events are a risk factor for the development of thyroid dysfunction [42-43], in Chapter 8, we have examined whether there is a relationship between EDS score and autoimmune thyroid dysfunction. In the final chapter, the main results, implications for, and recommendations to, general practice and primary care are discussed. 


\section{References}

1. Olshansky, S.J. Carmes, B.A., Cassel, C.K. (1993) The aging of the human species. So Am. April 1993: 46-52.

2. Hargrove, J.T., Eisenbergm E. (1995). Menopause. Med Clin. North Am.79:1337-1356.

3. Byyny, R.L., Speroff, L. A.(1996). Clinical guide for the care of older women: Primary and preventive care (Zend ed) Baltimore Md: Williams \& Wilkins.

4. Mckinlay, S.M., Brambilla, D.J., Posner, I.G. (1992). The normal menopause transition. Maturitas; 14:103-115.

5. Oldenhave, A. Jaszman, L.J.B., Haspels, A.A., Everaerd, Wth.A.M. (1993). Impact of climacteric on well being. Am J Obstet Gynecol 168: 772-780.

6. Van Hall, E.V., Verdel, M., Van der Velden, J.(1994). "Perimenopausal" Complaints in women and men: a comperative study. J Women's Health ; 3:45-49.

7. McKinlay, J.B., McKinlay, S.M. Brambilla, D.(1987). The relative contributions of endocrine changes and social circumstances to depression in mid-aged women. 1 Health $50 \mathrm{C}$ Behav; 28:345-363.

8. Hunter, M. (1992). The South - East Englaind longitudinal study of the climacteric and menopause. Maturitas; 14:17-126.

9. Avis, N.E., Brambilla, D., McKinlay, S.M., Vass, K.A. (1994). Longitudinal analysis of the association between menopause and depression: results from the Massachusetts Women"s Health Study. Ann Epidemial, 4:214-220.

10. Mckinlay, S.M. MCKinlay, J.B. (1973). Selected studies of the menopause: methodological critique. J Biosoc Sci,5:533-555.

11. Dennerstein, L. 5mith, A.M.A., Morse, C.A. (1994). Psychological well being, midlife and the menopause. Maturitas; 20:1-11.

12. Stouthamer, N., Visser, A.P., Oddens, B.J.(1993). Dutch general practitioner attitudes towards the climacteric and its treatment. Eur J Obstet Gynecol :50:147-52.

13. Barlow, D.H., Brockie, J.A. Riees, C.M.P. (1991). Study of general practice consultations and menopausal problems. BMJ;302:274-76.

14. Smeets-Goevaers, C.G., Leusink, G.L. Papapoullos, S.E., Maartens, L.W., Keyzer , J.J., Weerdenburg, J.P., Beyers, L.M., Zwinderman. A.H. Knottnerus, J.A., Pols, H.A., Pop. V.J. (1998). The prevalence of low mineral density in Dutch perimenopausal women. Osteoporosis Int, :8:654-9.

15. Panzarino, P.J. Jr. (1998). The costs of depression: direct and indirect; treatment versus non treatment. $J$ Clin Psychiatry:59 Suppl 20:11:4.

16. Revicki, D.A., Simon, G.E., Chan, K., Katon, W., Heikigenstein, J. (1998). Depression, health related quality of life, and medcal cost outcomes of receiving recommended levels of antidepressant treatment / Fam Pract Dec;47(6):446-52.

17. 5 turm, R., Wells, K.B. (1995). How can care for deperession become more cost-effective ? JAMA Jan 4:273(1):51-8.

18. Lave, J.R., Frank, R.G., Shulberg, H.C., Kamlet. M.S. (1998). Cost effectiveness of treatments for major depression in primary care. Arch Gen Psychiatry; 55:645-51.

19. Pop, V.J., de Rooy, H.A., Vader, H.L. et al. (1991). Postpartum thyraid dysfunction and depression in an unselected population. N Eng / Med;324:1815-816.

20. Ballinger, C.B. (1990). Psychiatric aspects of the menopause. Br J Psychiatry. $156: 773-781$. 
21. Hunter, M.5. (1990). Emotional well being, sexual behaviour and hormone replacement therapy Maturitas 1990a; 12:299-314.

22. Lock. M. (1994). Menopause in cultural context. Exp Gerontol,29:307-317.

23. Jaszman, L., Van Lith, N.D., Zaat J.C.A. (1969). The age at the menopause in the Netherlands. The statistical analysis of a survey, Med Gynec Soc; 4:256-77.

24. Brand, P.C. (1978). Age at menopause An incestigation into the median age at menopause in Ede, the Netherlands, and into the possible influence of certain environmental variables upon this age Dissertation Leiden. Elve/Labor Vincit 1978.

25. Groeneveld, F.P.M.J. (1994). The Climacteric: Blood, Sweat and Tears. Population based studies of well beingl, attitudes and hormorie replacement therapy among 1947 women aged 45-60 years. Thesis Rotterdam. ISBN 90-9007244-6.

26. Kanis, J.A, Delmas, P., Burckhardt, P., Cooper, C., Torgerson, D. (1997). Guidelines for diagnosis and management of osteoporosis. Osteoporos int:7:390-406.

27. Cummings, S.R., Black, D.M., Nevitt, M.C., et al. (1993). Bone density at various sites for prediction of hip fractures. Lancet; $341: 72-5$.

28. Melton, L.J., Atkinson, E.J. Fallon, W.M. Wahner, H.W., Riggs, B.L. (1993). Long-term fracture prediction by bone mineral assessed at different skeletal sites. I. Bone Miner Res; 8: $1227-33$.

29. Kanis, 3.A., Melton, L.J., Christiansen, C., Johnston, C.C., Khaltaev, N. (1994). The diagnosis of osteoporosis. IBone Min Res ; 9:1137-41.

30. Compston, J.E., Cooper, C., Kanis, J.A. (1995). Bone densitometry in clinical practice. $B M ; 310: 1507-10$.

31. Pouilles, J.M., Tremolliers, F., Ribot, C. (1993). Spine and femur desitometry at the menopause: are both sites necessary in the assessment of the risk of osteoporosis? Calcif Tissue int, 52:344-7.

32. Kröger, H., Tuppurainen, M., Honkanen, R., Alhava, E. Saarikoski, S. (1994). Bone mineral density and risk factors for osteoporosis: a population-based study of 1600 perimenopausal women. Cakif Tissue int; $55: 1 \times 7$

33. Michaëlsson, K., Bergström, Mallmin, H., Holmberg, L., Wolk, A., Lüunghall, 5. (1996). Screening for osteopenia and osteoporosis: selection by body composition. Osteoporos int : $6: 120-6$.

34. Oddens, B.J., Boulet, M. J., Lehert, P., Visser, A.P. (1994). A study on the use of medication for climacteric complaints in Western Europe li. Maturitas, 19:1-12.

35. Matthews, K., Wing, R. Kuller, L., et al. (1990). Influences of natural menopause on psychological characteristics and symptoms of middle-aged healthy women. I Consukt Clin Psychol ; 58 no3." 345-51.

36. Holte, A. (1992). Influences of natural menopause on health complaints: A prospective study of healthy Norwegian women. Maturitas; 14: 127-141.

37. Hagstad, A. Janson, P.O. (1986). The epidemiology of climacteric complaints. Acta Obster Gynecol Scand Suppl:134:59-65.

38. Bialinger, C., Browning, M., Smith. A. (1987). Hormone profiles and psycholagical symptoms in perimenopausal women. Maturitas ; 9:235-251.

39. Greendale, G. Judd, H. (1993). The Menopause: health implication and dinical management. IAm Ger Soc:41:426-436.

40. Barrett-Connor, E. (1993). Epidemiology and the menopause: A global overview. Int Fert;38 suppl 1:6-14. 
41. Nicol Smith, L. (1996). Causality, menopause and depression a critical review of the literature. BM, 313:1229-32.

42. Winsa, B., Adami, H.O. Bergstrom, R. et al. (1991). Sressfull lite events and Graves disease Lancet; $338: 1475-79$.

43. Kung. A.W. (1995). Life events, daily stresses, and coping in patients with Graves disease. Clin Endocrinol (Oxf):42:303-08

44. Lazarus, I.H. (1997). Hyperthyroidism Lancet; $349: 339-343$

45. Lindsay, R.S., Toft, A.D. (1997). Hypothyroidism. Lancet; 349:413-41\%.

46. Weetman, A.P. (1997). Hypothyroidism: screening and subclinical disease. $8 \mathrm{r}$ Med 314:1175-78. 

The prevalence of low bone mineral density in Dutch perimenopausal women: The Eindhoven Perimenopausal Osteoporosis Study

Published as: Smeets-Goevaers, C.G., Leusink, G.L., Papapoulos, S.E., Maartens, L.W., Keyzer, J.J., Weerdenburg, J.P., Beijers, L.M., Zwinderman, A.H., Knottnerus, J.A., Pols, H.A., Pop, V.J. (1998). The Prevalence of Low Bone Mineral Density in Dutch Perimenopausal Women: The Eindhoven Perimenopausal Osteoporosis Study. Osteoporos int 8: 404-409. 


\section{ABSTRACT}

The aim of this study was to estimate the prevalence of osteopenia and osteoporosis in perimenopausal women, and to assess determinants of low one mineral density (BMD). All women born between 1941 and 1947 (aged between 46 and 54 years? living in the city of Eindhowen were invited to participate in the study; 5896 white Dutch women, representing $73 \%$ of the total number of Dutch women in this age group, were studied. Of these, $24 \%$ were using estrogen preparations and $19 \%$ had undergone hysterectomy, with or without oophorectomy. All women were intervieved and bone mineral density (BMD) of the lumbar spine was measured by dual energy $X$-ray absorptiometry (DXA). Osteopenia and osteoporosis were defined according to the criteria proposed by a WHO working group. In the population studied the prevalence of osteopenia and osteoporosis was $27.3 \%$ and $4.1 \%$, respectively. With progression from premenopause to menopause, the prevalence of osteoporosis increased from $0.4 \%$ to $12.7 \%$, and that of osteopenia from $14.5 \%$ to $42.8 \%$. An increased risk for low BMD (osteopenia and osteoporosis) was associated with age, menopausal status, and smoking while alcohol consumption, high body mass index (BMI) and use of estrogens had a protective effect. This study of a large population-based cohort of perimenopausal women revealed a high prevalence of low bone mass and, therefore, a higher risk for asteoporotic fractures.

The data further suggest that, when issues on the long-term efficacy and safety of preventive treatments are resolved, it may be possible to identify women at higher risk who are most likely to benefit from screening strategies.

Keywords: Bone mineral density; Estrogens; Hysterectomy; Menopause; Osteopenia; Osteoporosis; Prevalence; Risk factors; Screening 


\section{Introduction}

Osteoporasis currently defined as a systemic skeletal disease characterised by low bone mass and microarchitectural deterioration of bone tissue with a consequent increase of bone fragility and susceptibility to fracture [1], is recognised as a major health probiem. Bone mass in later life is determined by the peak mass attained during growth and early adulthood and the rate of subsequent bone loss. in women, the period of accelerated bone loss following the loss of ovarian function is theoretically the best time for treatments aimed at preserving bone mass. provided that effective, safe and generally acceptable means are available. Therefore it is important to identify those women around the menopause who are at risk of developing osteoporosis and are most likely to benefit from such treatments. Screening of all women for low bone mineral density (BMD) around the menopause, as proposed by some authors $[2,3]$, is debatable and certainly not justified by the available data [4]. Alternative approaches are therefore needed. However, for the design of optimal strategies to prevent osteoporotic fractures, adequate knowledge of the problem around the menopause is essential. Prospective studies have shown bone mass measurements to be strong predictors of fractures $[5,6]$, and a WHO working party has proposed an operational definition for osteoporosis and diagnostic criteria based on BMD measurements [7]. In the present study we used these criteria to assess the prevalence of low bone mass and its determinants with special emphasis on gynaecologic variables in a large cohort of perimenopausal women.

\section{Subjects and Methods}

\section{Study Design}

Between September 1994 and September 1995, all women boin between 1941 and $1947(n=8503)$ who were living in the city of Eindhoven, The Netherlands, were invited to participate in the study by the Diagnostic Centre Eindhowen (DCE), a diagnostic centre for general practitioners, and the Department of Municipal Public Health Services, Eindhoven. Of the 8503 women, 8098 of whom were Dutch, $6846(81 \%)$ responded to the invitation and $6648(78 \%)$ agreed to participate in the study. In order to obtain homogeneous data comparable with other studies, the present analysis includes only white Dutch women, $6262(77 \%)$ of whom agreed to participate in the study. Of these, 31 women who failed to provide relevant information and 3 in whom (BMD) could not be measured, were excluded from the anallysis. Three hundred and thirty-two women were evaluated in a pilot, feasibility study and these results are not included either. Their mean BMD was $1.015 \pm 0.138 \mathrm{~g} / \mathrm{cm}^{2}$, while that of the remainder of the cohort $(n=5896)$ 


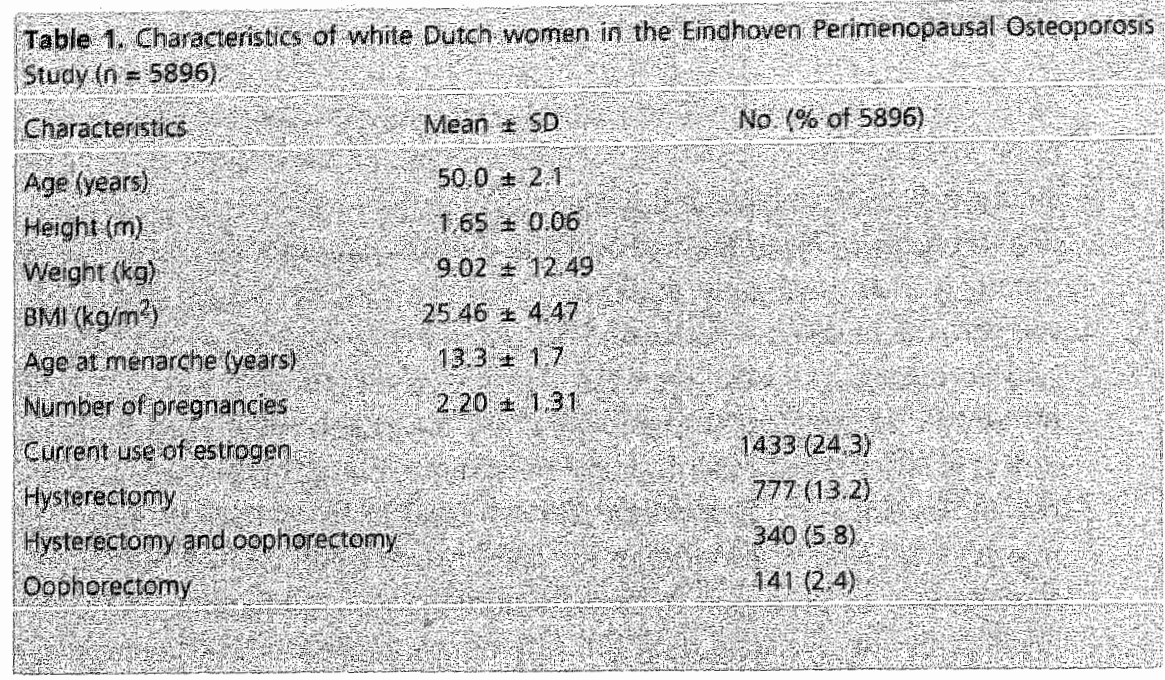

was $1.013 \pm 0.145 \mathrm{~g} / \mathrm{cm}^{2}$. A questionnaire was completed by all women, medical history was taken, clinical examination was performed and lumbar spine BMD was measured. Evaluation and measurements were performed at two centres: the DCE and St. joseph Hospital, Veldhoven, a suburb of Eindhoven. All responders gave their written informed consent and the study was approved by two medical ethics committees. The characteristics of all women studied are shown in Table 1.

\section{Menstrual status}

The following definitions were used:

1. Premenopausal: Women with regular menstrual periods, or those who had stopped using hormone replacement therapy (HRT) or oral contraceptives in the 3 months prior to screening, followed by a regular menstruation pattern.

2. Perimenopausal: (a) Women with irregular menses (at least one menstrual period in the preceding year). (b) Women who had stopped using HRT or oral contraceptives 3 months to 1 year prior to screening. followed by irregular menses. (c) Women who had stopped using HRT or oral contraceptives during the year before screening, followed by amenorhoea.

3. Menopausal: Women with amenormoea for 1 year or longer before screening

\section{Bone Mineral Density}

$B M D$ was measured at the lumbar spine $(L 1-4)$ by dual energy $X$-ray absorptiometry (DXA; S.A. Hologic Europe, Brussels). At the DCE, DXA model QDR-1000 S/N 291 was used, at St. Joseph Hospital, model QDR-2000 S/N 2260. 
Cross-calibration of the two densitometers was performed in nine volunteers. The Pearson correlation coefficient of these measurements was $0.9862, p<0.0001$. For quality control, two calibrations were performed daily using a spine phantom. The coefficient of variation for the DCE densitometer for the duration of the study was $0.54 \%$, calculated using a spine phantom with a value of $1.0354 \mathrm{~g} / \mathrm{cm}^{2}$. For the $5 \mathrm{t}$. Joseph Hospital densitometer this was $0.41 \%$, calculated using a different spine phantom with a value of $1.0409 \mathrm{~g} / \mathrm{cm}^{2}$. Vertebrae that could not be evaluated (due to calcification, operations, etc), were not included in the calculation of BMD.

According to the diagnostic criteria proposed by a WHO working party $[6]$ osteopenia is defined as a BMD between 1 and 2.5 standard deviations (SD) below the young adult mean (the T-5core). T-5core values below 2.5 are defined as osteoporosis. According to the reference data obtained by Hologic, the mean ( \pm SD) BMD of the spines (L1-4) of 650 healthy women studied at the University of San Diego, California, was $1.047 \pm 0.110 \mathrm{~g} / \mathrm{cm}^{2}$. Osteopenia is therefore defined as a value between 0.937 and $0.772 \mathrm{~g} / \mathrm{cm}^{2}$, and osteoporos 15 as a value below 0.772 $\mathrm{g} / \mathrm{cm}^{2}$. The mean BMD value of the premenopausal women in the present study was $1.069 \pm 0.129 \mathrm{~g} / \mathrm{cm}^{2}$ (mean \pm SD). The BMD equivalent to -1 and -2.5 SD was therefore 0.940 and $0.747 \mathrm{~g} / \mathrm{cm}^{2}$, respectiwely. Both thresholds were used for the calculation of the prevalence of osteopenia and osteoporosis in the whole cohort. The Hologic thresholds were used in the further analysis of the data.

\section{Statistics}

The statistics were performed with the use of the Statistical Products and Service Solutions (SPSS). To correct for confounding factors the relationship (odds ratio (OR) between low bone mass (osteopenia and osteoporosis) and potentiall determinants of BMD was examined by multivariate logistic regression analysis. The variables were hormonal use (use of HRT or oral contraceptives), age at screening and body mass index (BMI), gynaecological operations (hysterectomy, unilateral and bilateral oophorectomy), gynaecological parameters (menopausal status, age at menarche and previous pregnancies, smoking (current or past smokers). drinking (current alcohol consumption), and milk consumption before and after the age of 25 years.

\section{Results}

The mean ( \pm SD) BMD of the 5896 women studied was $1.013 \pm 0.145 \mathrm{~g} / \mathrm{cm}^{2}$ and. of these, $4.1 \%$ had asteoporosis and $27.3 \%$ osteopenia, according to the BMD thresholds provided by Hologic. When the BMD threshold obtained in our premenopausal women was used, the prevalence of osteoporosis and osteopenia 


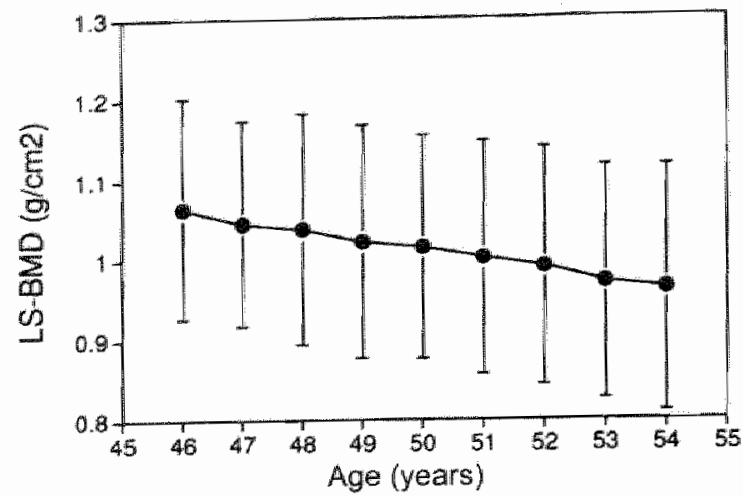

Figure 1. Bone mineral density of the lumbar spine (LS-BMD) in 5896 white Dutch women aged between 46 and 54 years (means and SDS).

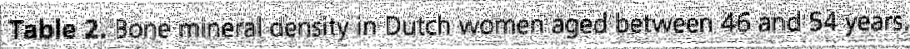

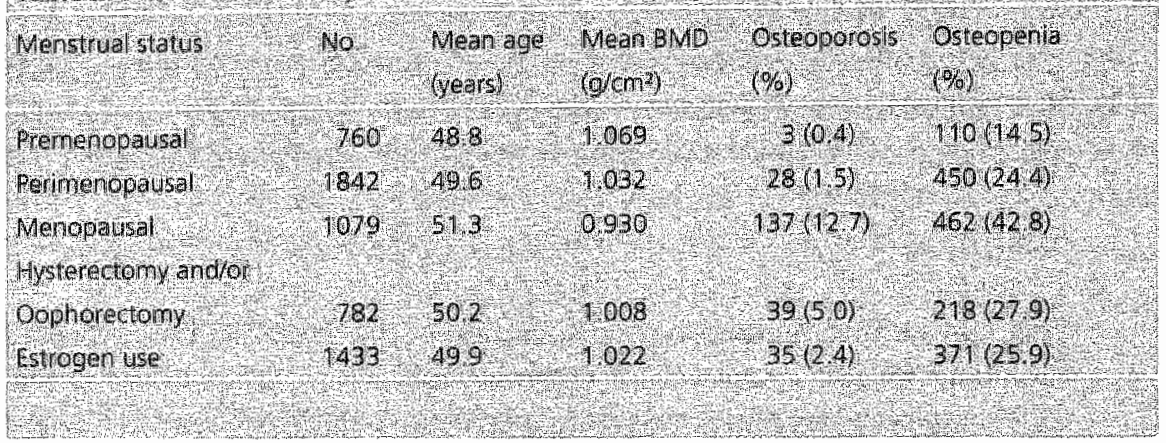

was $2.7 \%$ and $29.5 \%$, respectively; similar thus to that estimated with the use of the Hologic thresholds. As expected, there was a progressive decline in lumbar spine BMD with increasing age (Figure 1), due to the increasing presence of menopausal women in the higher age groups.

Separate analysis of perimenopausal women according to age showed that the prevalence of osteoporosis was $1.4 \%$ at 48 years and $1.3 \%$ at 53 years. The corresponding values for menopausal women of the same ages were $13.4 \%$ and $14.1 \%$, respectively. The prevalence of low bone mass (osteopenia and osteoporosis) in the postmenopausal women was related to the number of years since menopause (per year $O R=1,12, p<0.001$ ).

The BMD values and the prevalence of osteoporosis and osteopenia in the 3681 women in whom menstrual status could be determined are shown in Table 2 . 


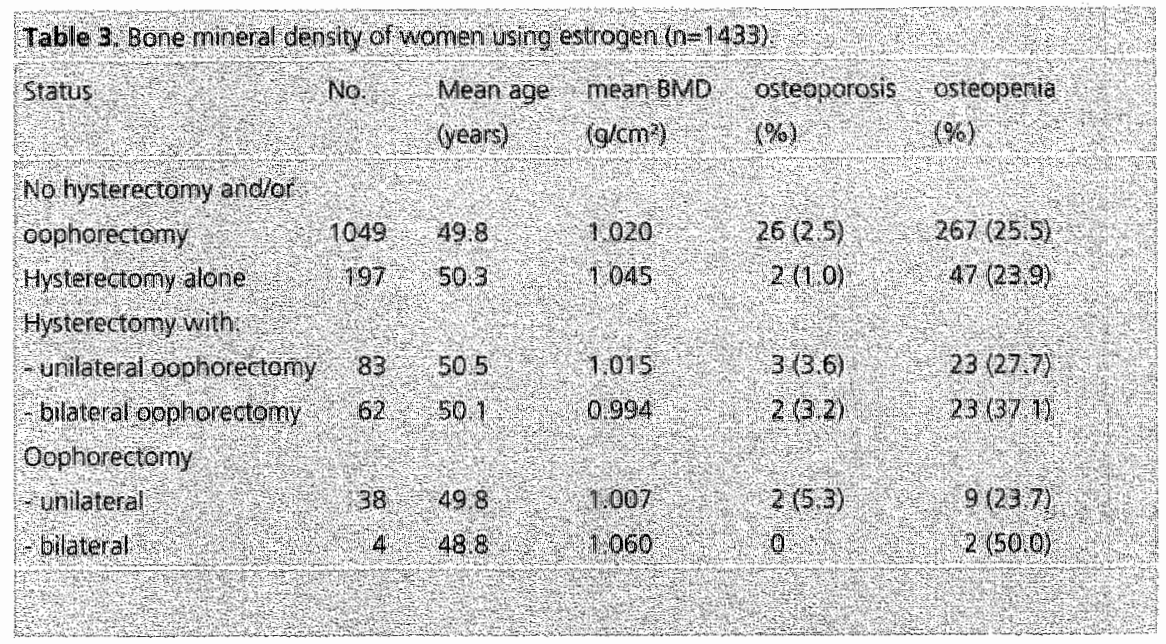

With progression from premenopause to menopause, there was an increase in the prevalence of osteoporosis from $0.4 \%$ to $12.7 \%$ within a narrow age range; the corresponding prevalence of osteopenia was $14.5 \%$ and $42.8 \%$, respectively.

In 2215 women, the menopausal status could not be determined due to hysterectomy, oophorectomy, use of HRT or oral contraceptives. Of these, 782 women did not use estrogen ( 580 had undergone hysterectomy, 195 hysterectomy and oophorectomy, and 7 bilateral oophorectomy). Their mean BMD was $1.008 \pm 0.149 \mathrm{~g} / \mathrm{cm}^{2}$ and $5.0 \%$ had osteoporosis, while $27.9 \%$ had osteopenia (Table 2). The prevalence of osteoporosis in women who had had a hysterectomy was $4.3 \%$, and this rose to $11.1 \%$ in those who had had hysterectomy and bilateral oophorectomy and to $28.6 \%$ in those who had had bilateral oophorectomy only. However, the number of women in the last group was too small to allow any definite conclusions. The mean BMD and prevalence of osteoporosis and osteopenia in the remaining 1433 women who used HRT or oral contraceptives are shown in Table 2 , and the respective values in subgroups of these hormone users in Table 3.

In these women, the prevalence of osteoporosis and osteopenia was also highest in those with bilateral oophorectomies with or without hysterectomies.

The results of the multivariate analysis of the risk factors for low bone mass (osteopenia and osteoporosis) are shown in Table 4.

An increased risk for low BMD was associated with age, peri- and postmenopausal status, bilateral oophorectomy and smoking, while alcohol consumption, high BMI and use of estrogens had a protective effect. To obtain more insight into the relation between gynaecological parameters and bone mass we further estimated the risks of the various subgroups (Table 5). 


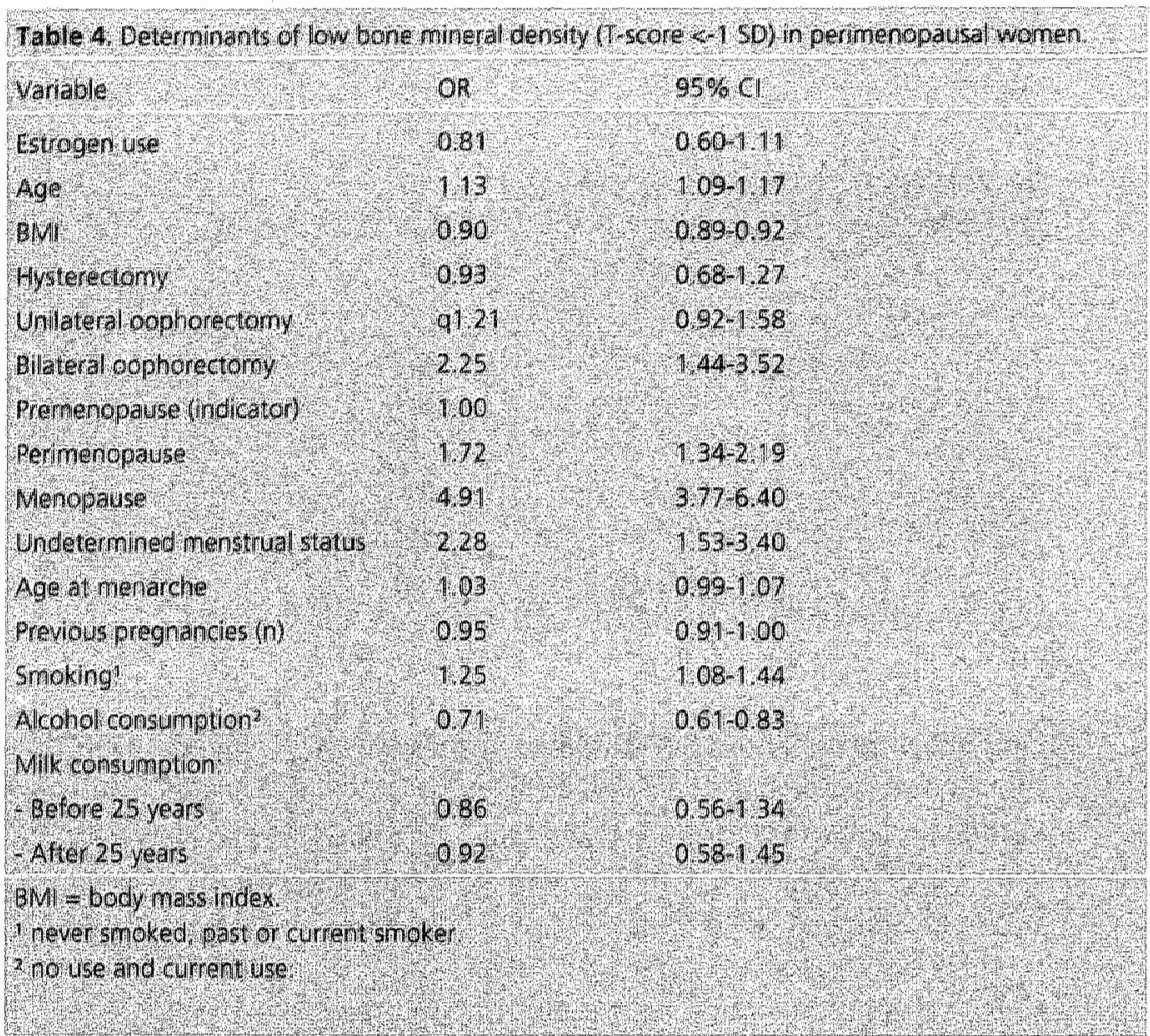

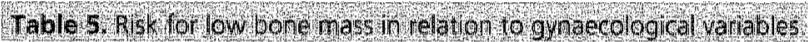

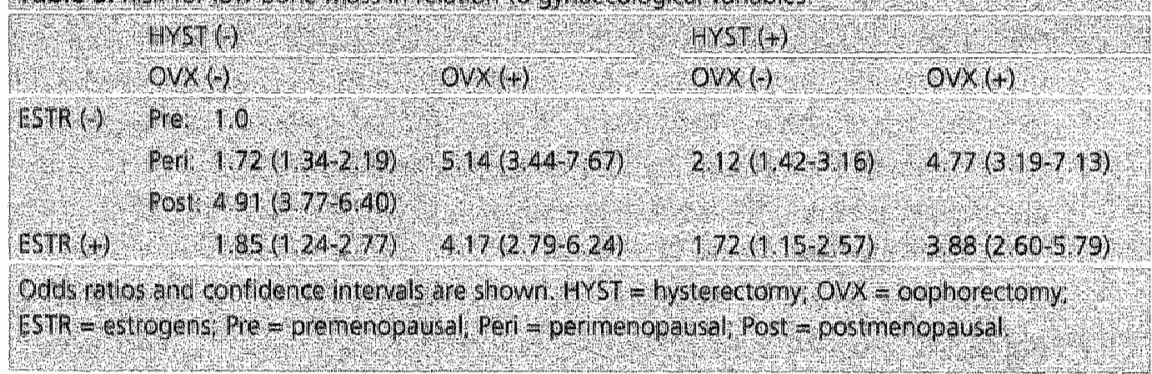

In general, gynaecological operations (hysterectomy, oophorectomy) increased the risk for low BMD, relative to premenopausal women, and the risk was always reduced by the concurrent use of estrogens. It should be noted, however, that the prevalence of low bone mass corrected for age, was related to the number of years since the operation (hysterectomy, OR 1.04 per year, $p=0.001$, bilateral oophorectomy, OR 1.05 per year ${ }_{2} p=0.07$ ). 


\section{Discussion}

The present study of a large population-based cohort of perimenopausal women, revealed the presence of osteoporosis and osteopenia of the axial skeleton in $4.1 \%$ and $27.3 \%$ of the women, respectively. For this classification, the definitions for osteoporosis and osteopenia proposed by a WHO study group were used, together with threshold values of BMD provided by the manufacturer of the bone densitometer. These values were obtained in young healthy American women and are comparable to those reported in the UK [9] and Germany [10], as well as to those obtained in the premenopausal women in our study (mean BMD $1.047 \pm$ $0.110 \mathrm{~g} / \mathrm{cm}^{2}$ and $1.069 \pm 0.129 \mathrm{~g} / \mathrm{cm}^{2}$, respectively). However, although the mean BMD of our premenopausal group is slightly higher than that of the American population, the SD is larger, accounting for a lower BMD threshold for defining osteoporosis: $0.747 \mathrm{~g} / \mathrm{cm}^{2}$ compared with $0.772 \mathrm{~g} / \mathrm{cm}^{2}$ using the manufacturer's data. Using this threshold, we diagnosed osteoporosis and osteopenia in $2.7 \%$ and $29.5 \%$ of the women, respectively. It should be mentioned that these reference values were obtained in an unselected group of premenopausal women who were, however, older than 45 years. Bone mass in such women may not be representative of the peak bone mass, as some bone loss may occur even before the menopause [11]. Furthermore, the present estimates of osteoporosis and osteopenia are based on BMD measurements at a single skeletal site, the lumbar spine, which may be an underestimation of the general risk for osteoporotic fractures. We chose to measure this site because trabecular bone is more sensitive to changes in estrogen status which are likely to occur in this narrow age-range group of women.

Our findings, therefore, while emphasizing the need for obtaining well-defined normal ranges for $\mathrm{BMD}$, underline the high risk for osteoporotic fractures in relatively young women, even using the most conservative criteria for diagnosis. Our data, which were obtained in an unselected population cohort, cannot be compared directly with those obtained in other studies, mainly due to different study designs and subject selection characteristics. They are, however, generally in agreement with the results of studies of women of similar ages in the UK [12] and France [13] evaluated in menopause clinics and of a select Finnish population cohort of 1600 women [14].

Even within the narrow age-range of the women in our study, there was a clear age-related decrease in BMD of the lumbar spine. This was due more to the increased representation of menopausal women in the higher age groups than to an effect of chronological age per se. Separate analysis of perimenopausal women according to age showed that the prevalence of osteoporosis was $1.4 \%$ at 48 years and $1.3 \%$ at 53 years. The corresponding values for menopausal women were $13.4 \%$ and $14.1 \%$, respectively. Indeed, menopause was found to be a wery strong risk factor for low BMD which was also related to years since menopause. 
On the other hand, a high BMI and use of estrogen had al protective effect on the skeleton, as commonly reported [15]. From our data it appeared initially that hysterectomy was associated with an increased risk of low bone mass when this group was compared with premenopausal women. Caution is needed however, in interpreting this result, as the prevalence for low bone mass adjusted for age was also related to the years since the operation in these women, which might have accounted for a higher representation of menopausal women. Nevertheless, the use of estrogens decreased this risk. The number of hysterectomies varies greatly in different countries $[16,17]$, reflecting local gynaecological practices rather than absolute indications for performing the operation. [18]. Our findings, though not defenite, suggest that an increased risk of osteoporosis may be considered a potential complication of this operation in young women, which can be, however, reduced by estrogen use. Of the other commonly assessed risk factors for osteoporosis, smoking had a negative effect on BMD, while alcohol consumption had a protective one.

The question arising from the present study is whether the results of this large unselected cohort of perimenopausal women can help in the design of preventive strategies, a subject that is currently under debate [19-22]. Twenty-four percent of the women studied were using estrogen preparations and, in these cases, BMD measurements are not indicated [22]. Premenopausal women, representing $13 \%$ of our population, can also be excluded from screening due to the lack of an effective treatment in this group. This leaves $63 \%$ as potential candidates for BMD screening. As shown here, however, the greatest differences in BMD occur between the perimenopause and the menopause and more than half of the total number of the menopausal women of this age group, not using estrogen, had either osteoporosis or osteopenia. Thus, screening of these women $18.3 \%$ of the total population) is likely to reveal low bone mass in $55 \%$. The chances of detecting a low bone mass are highest in this group of wornen. When it can be shown prospectively that safe and effective treatments that preserve or increase bone mass at the menopause, protect against fractures later in life, screening of these women might be realistic. However, until the above-mentioned requirements are fulfilled, we do not feel that screening is indicated around the menopause, and BMD measurements should only be performed in this age group according to specific indications [2].

Acknowledgements. This study was supported by a grant from the Dutch Praeventiefonds (project no. 002824010). We thank P. v. Nierop, epidemiologist of the Department of Municipal Public Health Services Eindhoven, for his help in the recruitment of the participants and I.H. Komproe (Free University of Amsterdam) for his help in the statistical evaluation of the data. 


\section{References}

1. Consensus development conference: diagnosis, prophylaxis, and treatment of osteoporosis (1993) Am I Med, 94: 646-50.

2. Johnston, C.C., Melton, L.J., Lindsay, R., et al. (1989). Cinical indications for bone mass measurements: a report from the scientific advisory board of the National Osteoporosis Foundation. 1 Bone Min Res; 4 : 1-28.

3. National Health Technology Advisory Panel. Bone mineral assessment: an update. Canberra: Australian Institute of Healih.

4. Kanis, J.A., Deimas, P., Burckhardt, P., Cooper, C., Torgerson, D. (1997). Guidelines for diagnosis and management of osteoporosis. Osteoporos int; 7:390-406.

5. Cummings, S.R., Black, D.M. Nevitt, M.C., et al. (1993). Bone density at various sites for prediction of hip fractures. Lancet; 341:72-5.

6. Melton, L. .. Atkinson, E.J., Fallon, W.M., Walhner, H.W., Riggs, B.L. (1993). Long-term fracture prediction by bone mineral assessed at different skeletal sites. J. Bone Miner Res, 8:1227-33.

7. Kanis, I.A. Meltonm L.J., Christiansen, C., johnston, C.C., Khaltaev, N. (1994).The diagnosis of osteoporosis. JBone Min Res, 9:1137-41.

8. Algra, A., Tijssen, J.P.G., Roelandt, J.R.T.C., Pool, J. Lubsen, J. (1993). Contribution of the 24 hour electrocardiogram to the prediction of sudden coronary death. Br Heart $J$ 70:421-27.

9. Ryan, F.J., Spector, T.P., Blake, G.M., Doyle, D.V., Fogelman, 1. (1993). A comparison of reference bone mineral density measurements derived from two sources: refierred and population based. Br J Radiol, 66:1138-41.

10. Lehmann, R., Wapniarz, M., Randerath, O.x et al. (1995). Dual-energy X-ray absorptiometry at the lumbar spine in German men and women: a cross-sectional study. Calcif Tissue int ; 56:350-354

11. Citron, J.T., Ettinger, B., Genant, H.K.. (1995). Spinal bone mineral loss in estrogen-replete, calcium*replete premenopausal women. Osteoporosis int ;5:228-233.

12. Compston, J.E., Cooper, C., Kanis, J.A. (1995). Bone densitometry in clinical practice. BMi;310:1507-10.

13. Poullles, J.M., Tremolliers, F., Ribot, C. (1993). Spine and fermur desitometry at the menopause: are both sites necessary in the assessment of the risk of osteoporosis? Calcit Tissue int, $52: 344-7$.

14. Kröger, H., Tuppurainen, M., Horkanen, R., Alhava, E., Saarikoski, 5. (1994). Bone mineral density and risk factors for osteoporosis: a population-based study of 1600 perimenopausal women. Calcif Tissiue int, 55:1-7.

15. Michaëlsson, K., Bergström, Mallmin, H., Holmberg, L., Wolk, A., Ljunghall, S. (1996). Screening for osteopenia and osteoporosis: selection by body composition. Osteoporos int 6:120-6.

16. McPherson, K. Strong, B., Epstein, A., Jones, L. (1981). Regional variations in the use of common surgical procedures: within and between England and Wales, Canada and the United States of America. Sor SCi Med; 15A:273-88.

17. Coulter, A. McPherson, K, Vessey, M. (1988). Do British women undergo too many or too few hysterectomies? Soc Soi Med:27:987-94.

18. Lilford, R.J. (1997). Hysterectomy: will it pay the bills in 2007? Treatment of choice for cancer, but a choice of treatment for menorhagia. BMJ:13:160-1. 
19. Law, M., Wald, T.J., Meade, T.W. (1991). Strategies for the prevention of osteoporosis and hip fracture $B M, 303: 453-9$.

20. Ringa, $V_{,}$, Durieux $x_{x}$. Breart, $G$. (1994). Bone mass measurements around menopause and prevention of osteoporotic fractures. Eur J Obstet Gynecol Reprod Biol ; 54:205-3.

21. Black, D.M. (1995). Why elderly women should be screened and treated to prevent osteoporosis. Am J Med, $98.67-75$.

22. Mcknight, A., Steele, K., Mills, K., Gilchrist, C., Taggart, H. (1995). Bone mineral density in relation to medical and lifestyle risk factors for osteoporosis in premenopausal, menopausal and postmenopausal women in general practice. $B r J$ Gen Pract $455317-20$. 


\section{Climacteric complaints in an open community}

In Press. Family Practice. 2000. Maartens, L.W., Leusink, G.L., Knottnerus, J.A., Smeets-Goevaers, C.G., Pop, V.J. Climacteric complaints in an open community. 


\section{ABSTRACT}

Background: At the onset of the climacteric, healthy middle aged women present with a wariety of complaints, especially in general practice. In these first years of entering the menopause, vaginal blood loss alters firom irregular periods to complete amenorrhoea. According to these different menstrual patterns we can distinguish a pre-, peri- and postmenopausal phase. It could be useful to know whether specific climacteric complaints are related to these different phases.

Objective: To investigate the relation between climacteric complaints and menstrual pattern during the menopausal transition in a population-based cross-sectional survey of healthy middle aged women.

Method: All women aged 47.54 years, living in the city of Eindhoven were invited to participate in the Eindhoven Osteoporosis Study (EPOS); 6648 $(78 \%)$ agreed to participate. All women completed a questionnaire concerning dimacteric complaints. Climacteric status was defined by menstrual history. Odds ratios were obtained for the relationship between climacteric status and climacteric complaints. Multiple logistic regression analysis was carried out, with climacteric status as the dependent variable. Results: Of the 27 items in the questionnaire concerning climacteric complaints, 7 were significantly different between all three climacteric phases ( $p<0.1)$. After multiple logistic regression analysis, comparing peri and premenopause, only flushing (OR 5.9) was significantly different. Between post- and perimenopause 7 symptoms appeared to be different: three urogenital complaints (vaginal dryness (OR 1.6), waginal discharge (OR 0.4 ) and pain during intercourse (OR 1.9)), three vasomotor symptoms: (day sweating (OR 1.4), night sweating (OR 0.7) and flushing (OR 1.93) and finally insomnia (OR 1.3). When comparing post- and premenopause, flushing (OR 13.4), insomnia (OR 2.1) and depressed mood (OR 0.6) were significantly different, beside three urogenital symptoms: vaginal dryness (OR 2.6). vaginal discharge (OR 0.3 ) and pain with intercourse (OR 2.1).

Conclusion: The major findings of the study are that flushing is strongly associated with the transition from pre- to perimenopause while urogenital complaints, day sweating and insomnia are more prominent in the transition from peri- to postmenopause.

Keywords: Menopause, Epidemiology, Cross-sectional, Climacteric, Population based 


\section{Introduction}

In the assessment of climacteric complaints in perimenopausal women, the importance of delineating which symptoms can be attributed to menopausal status has been stressed repeatedly. Seventy to eighty percent of women around the menopause have been reported to present with dimacteric complaints [1], which can be categorized as vasomotor, genito-urinary, neurological, psycho-social and musculo-skeletal. Climacteric complaints are said to be typical when they concen vasomotor complaints such as flushing, (night)sweating and atrophy of the urogenital epithelium, with vaginal dryness and pain during intercourse as a consequence. These typical complaints are considered to be related to climacteric hormonal changes. Although many hormone changes have been studied, none of these have been shown to have any value in the prediction of either the duration or the severity of symptoms and complaints $[2,3]$. Other factors which decrease estrogen production, such as smoking, alcohol intake and low body mass index. are reported to be related to the occurpence of hot flushes at the time of menopause [4]. As far as atypical complaints are concemed, much obscurity and incomprehension still exists among women, general practitioners (GPs) and other clinicians. This might be due to the fact that most research was mainly based on clinical trials carried out to investigate symptomatic relief subsequent to estrogen therapy [18]. Moreover, most of the data were collected among women attending menopausal clinics, which is a highly selected study population. Finally, most of the published data refer to samples in which the age range varied widely, which makes it difficult to define several complaints as being specific to menopausal transition. It would be of clinical relevance to know which complaints occur most frequently in this relatively short time span, and how specific they are, especially for the GP, who can be regarded as the main climacteric counsellor for healthy middle aged women. For this purpose it would be heipful to discriminate complaint patterns within the menopausal transition between the different phases generally defined as pre-, peri and postmenopause. Therefore, we conducted a cross-sectional general population survey among Dutch Caucasian women.

\section{Methods}

Between September 1994 and September 1995, all women ( $n=8503$ ) borm between 1941 and 1947 and living in the city of Eindhoven, the Netherlands, were invited to participate in a screening programme for osteoporosis, known as EPOS [5] (the Eindhoven Perimenopausal Osteoporosis Study). Of the 8503 women. $6846(81 \%)$ responded to the inwitation and $6648(78 \%)$ agreed to participate in the study. This sample was screened by medical history, bone mineral density by 


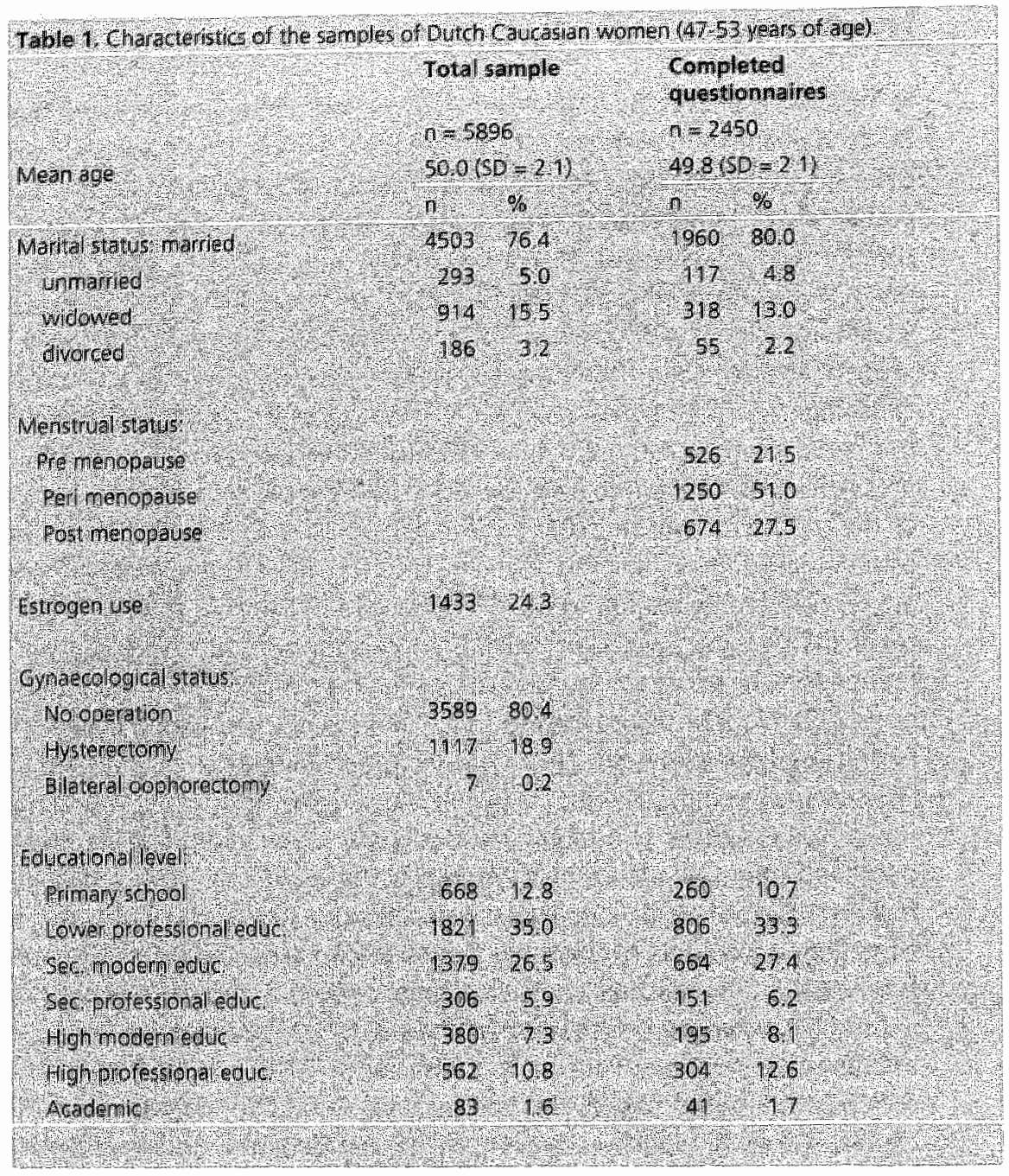

DXA and blood samples. All women completed a questionnaire at home. Of the women screened, 5896 were Dutch Caucasian. Non-Dutch Caucasian women $(n=734)$ were excluded because of possible language problems.

To investigate the normal climacteric period and to have the possibility of arsessing the current menstrual cycle, the following categories of women were excluded from the analysis: women having had a hysterectomy (with or without oophorectomy) ( $n=1117)$; women having had a bilateral oophorectomy $(n=11)$; users of estrogens/progestagens, $(n=1433), 75.9 \%$ of whom had not had a hysterectomy and/or a bilateral oophorectomy. 
A further 1622 women ( $27.5 \%$ ) were excluded because of non-compliance with one or more items in the questionnaire. In this excluded group, age, climacteric status, employment, marital status and educational level were equally distributed compared with the original sample of Dutch Caucasian women. In total, 2450 completed questionnaires were available for analysis (Table 1).

Climacteric status was classified in three categories, based on the women's menstrual history [6]: premenopause: regular menstruation pattern; perimenopause: irregular menstrual cycle (at least one period in the last year) and postmenopause: amenorrhoea for one year prior to screening.

We used the validated questionnaire of Oldenhave and Jaszman [7] covering 24 complaints and added three items: vaginal dryness, pain during intercourse and waking at night.

The analysis was carried out using the Statistical Products and Service Solutions (SPSS). The severity of the complaints was indicated on a four-point scale: absent. slight, moderate and severe. In order to compare the complaints, they were divided into absent $(=0)$ and present (slight/moderate/severe) $(=1)$. First the chi-square test for independent samples was carried out to compare the frequency of occurrence of the complaints in the three categories of climacteric status using a two sided significance level of $p<0.05$. The complaints that showed differences at a univariate level with a p-value $<0.1$. were entered into a multiple logistic regression analysis in order to obtain adjusted odds ratios (with $95 \%$ confidence intervals) for the relationship between climacteric status (dependent variable) and complaints (independent variables) during the menopausal transition. Adjusted odds ratios were estimated for each menopausal transition step: pre-peri, peri-post and overall, pre-post respectively.

\section{Results}

The frequency of the presented complaints, according to menopausal status, are set out in Table 2.

Moreover, significant differences between the different phases are mentioned.

After backward stepwise multiple logistic regression analysis we found, in the comparison between post -and premenopause, that six items were significantly different (Table 3). Four of these six items were significantly more prevalent in the postmenopausal group: vaginal dryness, pain during intercourse, flushing and insomnia. Vaginal discharge and depressed mood were significantly less often present in the postmenopause. When we compared peri - and premenopause, only one item proved to be significantly different: flushing, which was more prevalent in the peri-menopause. (Table 3). Comparing postmenopausal complaints with perimenopausal, seven items were significantly different. Five items were more prevalent in the post-menopause: vaginal dryness, pain during intercourse, 


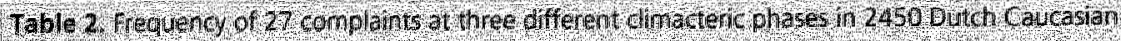
Momen, iged 4753 jears (Chisquare)

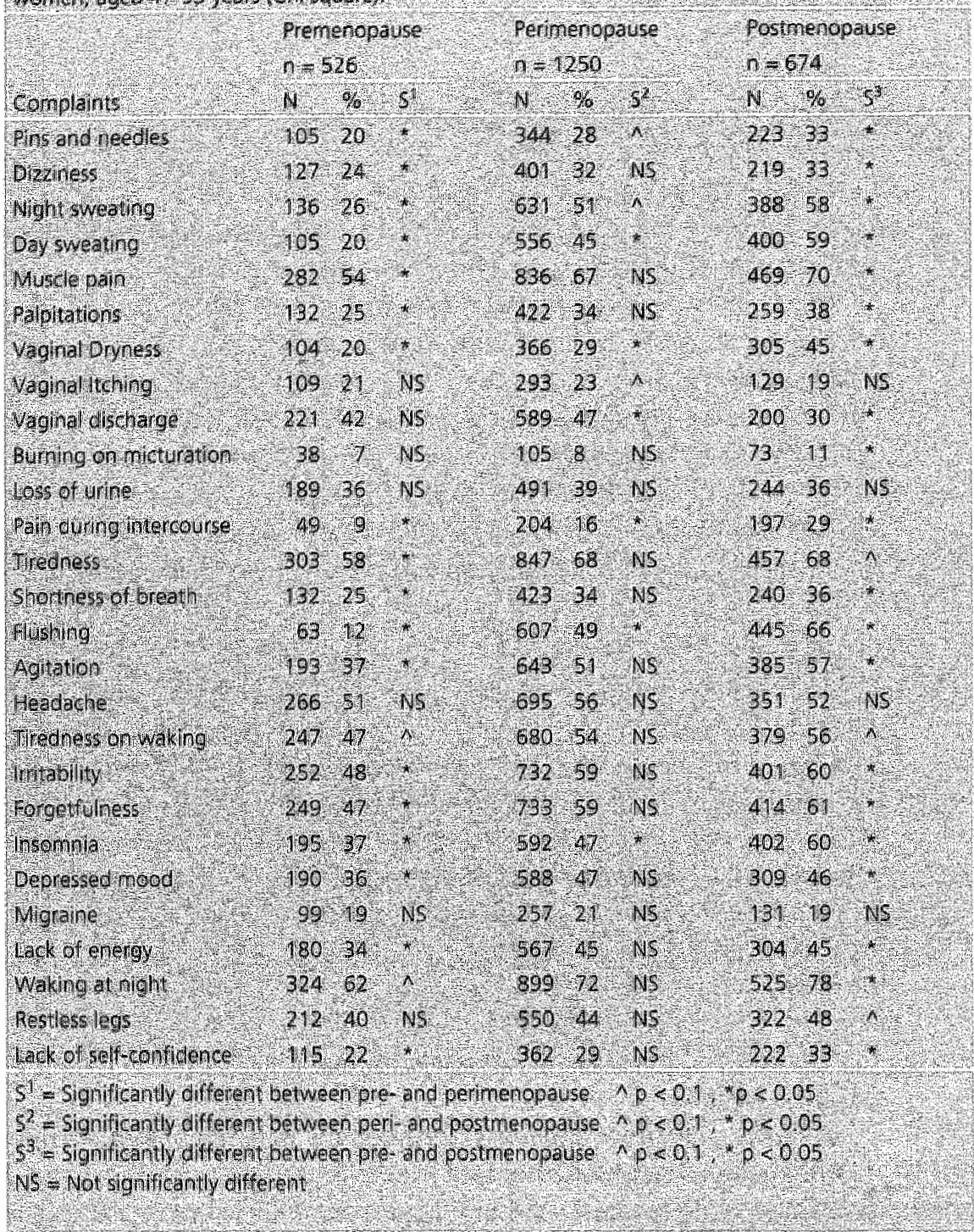

flushing, day sweating and insomnia; while two items were less prevalent: vaginal discharge and night sweating (Table 3 ).

When we compared post- and premenopause and post- and perimenopause three uro-genital complaints (vaginal discharge, vaginal dryness, pain during intercourse) were independently significantly different. In the comparison between peri- and premenopause, no urogenital complaints were seen significantly more frequently in any of the categories. 


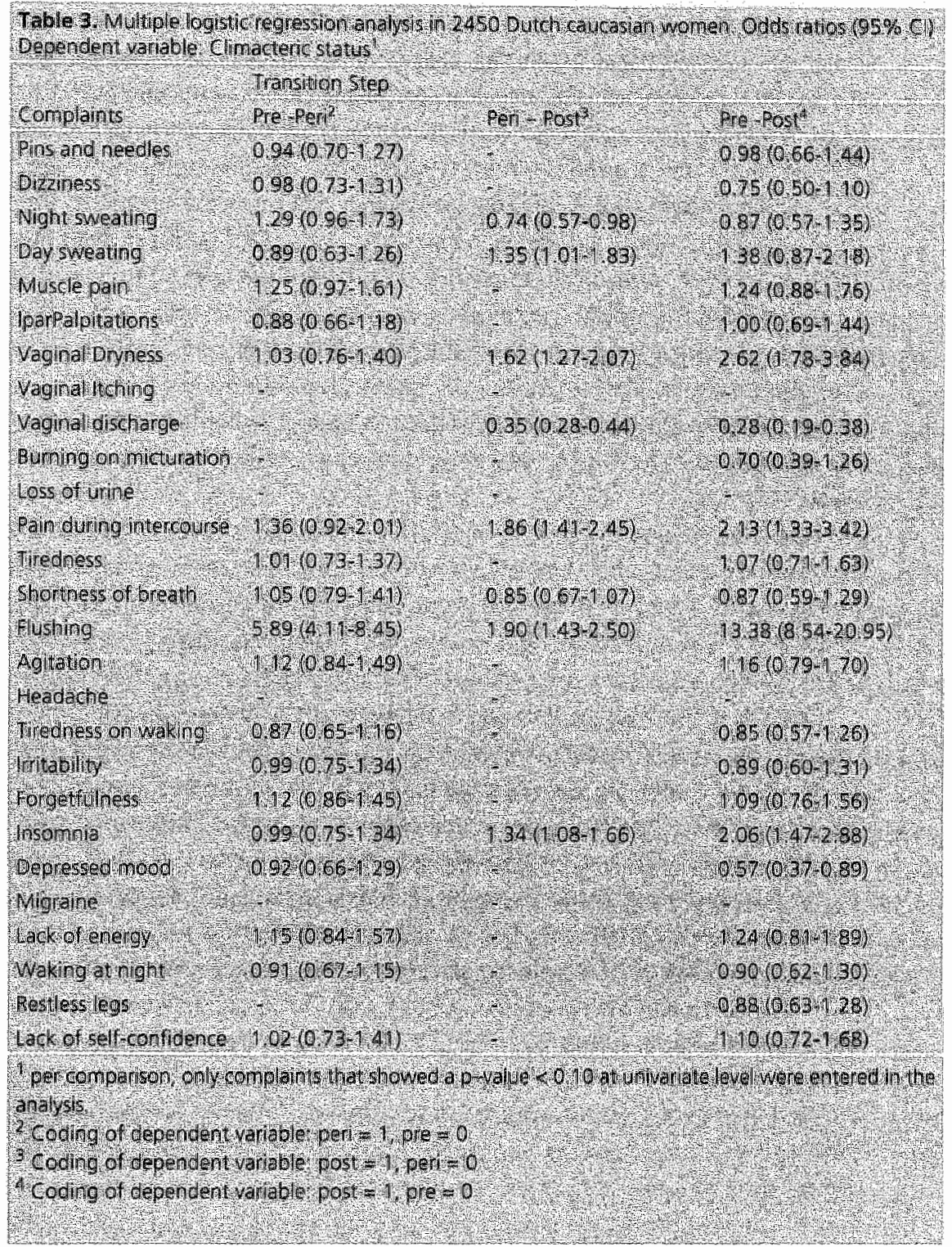

\section{Discussion}

The lack of agreement between epidemiological surveys evaluating climacteric complaints can be explained by methodological differences [8]. Most large-scale cross-sectional and longitudinal studies concern women seeking medical attention, visiting menopausal clinics [17] and volunteers attending screening 
programmes [9]. Only a few studies used random samples from the community $[10,11,12]$. Therefore, the samples used for most studies are not representative of the general population. This can lead to selection bias and reduces the possibility of generalizing the results. The present study is based on a large population based sample of worren around the menopause with a narrow age range (47-53 years). The results of our study apply only to women not using hormones at the time of the climacteric About $24 \%$ of the women in the EPOS cohort used homones: $10 \%$ used HRT and 14\% used oral contraceptives and these women were excluded from the study. A proportion of women who choose to use HRT may be doing so to relieve some of the climacteric complaints investigated in this study. Theretore if these women would not have used HRT and would have been in the study, the percentage of women having complaints might have been higher and the correlation between complaints and menopausal transition even more prominent.

As far as we know, there are no other publications of cross-sectional general population surveys of this magnitude that studied as narrow an age range as the one we used. Most of the larger cross-sectional studies used a much wider age range and the observed changes in symptomatology could be the result of ageing. physical changes, experiences due to situational change, or cohort differences.

The GP is the most suitable climacteric counsellor for (healthy) middle aged women, and has to know which complaints are related to the various categories of climacteric status. By knowing the epidemiology of the variables examined, the GP can estimate the complaints at their true value with regard to the menopausal state $[13,14,15]$. This may also have implications for the way in which middle aged women's views and behaviour are perceived by society [16]. Especially at the onset of the climacteric, there is no clinical sign that the transition has begun. Drawing conclusions retrospectively after a one-year period of amenorhoea, is much easier than labelling symptoms as climacteric during the perimenopausal period. while there is still vaginal blood loss. GPs should have the possibility of assessing the probable onset of the clinacteric by a simple questionnaire. With this knowledge, the GP could estimate the complaints presented at their true value with regard to the coming menopause. In our study, flushing was the only symptom that was significantly different when we compared all three menopausal phases together. Part of the vasomotor symptom complex (night-sweating and day-sweating) was only significantly different in multiple logistic regression analysis between postand perimenopause. In our survey, in the premenopause $3 \%$ and $1 \%$ of the women, respectively, presented with moderate or severe complaints of flushing. while in the perimenopause $16 \%$ and $10 \%$ respectively presented with these symptoms. In the perimenopause, the chance of flushing is much higher than in the premenopause ( $O R=5.9$ ) and the odds ratio is much smaller for the difference between post- and perimenopause $(O R=2.00)$. Oldenhave and Mckinlay also 
found the highest prevalence of modest and severe vasomotor complaints in the late premenopause (6-12 months since last menstrual blood loss) [10].

We conclude that, in healthy middle aged women at the onset of the climacteric only flushing discriminates between pre-and perimenopause, suggesting the start of the menopausal transition.

The cluster of so-called typical climacteric complaints of the urogenital tract does not discriminate between pre- and perimenopause. The frequency of vaginal discharge, vaginal dryness and pain during intercourse is significantly different between perimenopause and postmenopause. One major finding of the study is that only flushing plays an important role in the onset of menopausal transition while urogenital complaints are more important when irregular vaginal blood loss proceeds towards a complete stop. The prevalence of insomnia is different between pre- and postmenopause and between peri * and postmenopause, while other variables concerning sleep, such as waking at night and tiredness on waking, are never significantly different. Although it has often been suggested that insomnia is related to nightly vasomotor problems [8], especially between post- and premenopause we found insomnia to be independently different, whereas night-sweating was not. Waking at night is the most frequent complaint in pre- peri- and postmenopause (present in $62 \%, 72 \%$ and $78 \%$, respectively) without being significantly different at any menopausal phase (Table 2).

In our cross-sectional data we found that $19 \%$ of women in the age range of 47-53 years had had a hysterectomy but had at least one ovary in situ (Table 1). These women no longer have vaginal blood loss so their transition to menopause cannot be assessed by a changing menstrual pattern. For this large subgroup, our findings of specific complaints in the early onset of the climacteric and later on towards postmenopause can be very helpful. For individual women it is easier to answer the question of whether the transition from a normal menstrual pattern to complete amenorhoea will be associated with typical complaints.

A major limitation of this study is the fact that we are attempting to make statements about the menopausal transition in a cross-sectional study. Cross-sectional designs can identify associations and can only suggest changes over time. Longitudinal cohort designs with repeated measurements in the same women, can identify a temporal sequence in events or rate changes. Our obserwations still need to be confirmed in prospective studies.

Acknowledgements. This study was supported by a grant from the Dutch Praeventiefonds (project No.002824010) We would like to thank P. wan Nierop. epidemiologist with the Municipal Public Health Services, Eindhoven, for his help in the recruitment of the participants. 


\section{References}

1. Schwingl, P.J., Hulka, B.S., Harlow, S.D. (1994). Risk factors for menopausal hot flashes, Obstet Gynecol,84:29-34.

2. Ballinger, C.B., Browning, MI.C.K., Smith, A.H.W. (1987). Hormone profiles and psychological symptoms in perimenopausal women.Maturitas:9:235-51

3. Ginsburg, 1., Hardiman, P. (1991). What do we know about the pathogenesis of the

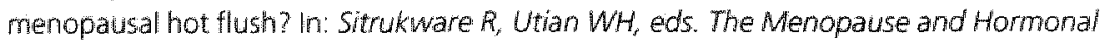
Replacement Therapy, 15-46. New York: Marcel Dekker Inc.

4. Den Tonkelaar, I., Seidell, J.C. Van Noord, P.A.H. (1996). Obesity and fat distribution in relation to hot flashes in Dutch women from the DOM project. Maturitas;23:301-305.

5. Smeets-Goevaers, C.G., Leusink, G.L., Papapoulos, S.E., Maartens, L.M., Keyzer, J... Weerdenburg, J.P., Beyers, L.M. Zwinderman, A.H., Knotnerus, J.A., Pols, H.A., Pop. VJ (1998). The prevalence of low mimeral density in Dutch perimenopausal women Osteoporosis int: $8: 654-9$

6. Mckinlay, S.M., Brambilla, D.J. Posner, 1.G. (1992). The normal menopause transition Am J Hum Biol ; $4: 37-46$.

7. Oldenhave, A., Jaszman, J.B., Haspels, A.A., Everaerd, W.T. (1993). Impact of climacteric on well being. Am J Obst Gyn; 168:772-80.

8. Kaufert, P. Gilbert, P., Hasserd, T. (1988). Researching the symptoms of menopause: an excercise in methodology. Maturitas; 10:117-31.

9. Hunter, M., Battersby, R., Whithead, M. (1986). Relationships between psychological symptoms, somatic complaints and menoapusal status. Maturitas;8:217-28.

10. Mckinlay, S.M., Mckinlay, J.B. (1986). Health status and health care utilisation by menopausal women. In: Notelowitz $M_{\text {r }}$ Van Keep $P$, eds. The Climacteric in Perspective, pp59-75. MTP Press Ltd Lancaster.

11. Kaufert, P.A. (1984). Women and their health in the middle year: a Minnitoba project. Soc Sci Med, 18:279-81.

12. Holte, A., Mikkelsen, A. (1991). The menopausal sydrome: a factor analytic replication. Maturitas; 13:193-203.

13. Barlow, D.H., Brockie, J.A. Rees, C.M.P. (1991). Study of general practice consultations and menopausal problems. BM, 302:274-76.

14. Stouthamer, N., Wisser, A.P., Oddens, B.J. (1993). Dutch general practitioner attitudes towards the climacteric and its treatiment. Eur J Obstet Gynecol:50:147-52.

15. Groeneweld, F.P.M.J., Bareman, F.P., Barentsen, R., Dokter, H.J., Drogendilk, A.C., Hoes, A.W. (1993). The climacteric and well being, I Pyychosom obstet Gyn,51:203-207.

16. Holte, A. (1992). Influences of natural menopause on health complaints: a prospective study of healthy Nonvegian women. Maturitas; 14:127-41.

17. De Aloysio, A. Fabiani, A., Maulini, M., Bottiglioni, F. (1989). Analyis of the climacteric syndrome Maturitas; 11:43-53.

18. Maartens, L.W., Leusink, G.L., Knottner Lis, J.A. Pop, V.J. (2000). Hormonal substitution during menopause: What are we treating? Maturitas;34(2): $113-18$. 


\section{Hormonal substitution during}

menopause: What are we treating?

Published as: Maartens, L.W., Leusink, G.L., Knottnerus, J.A., Pop, V.J. (2000).

Hormonal substitution during menopause: What are we treating? Maturitas; $34(2)$, 13-18. 


\section{$A B S T R A C T$}

Objectives: It is suggested that during menopausal transition, women with vasomotor symptoms benefit from HRT (Hormone Replacement Therapy) wheras the use of HRT for other cognitive / vegetative symptoms is questionnable.

Methods: The occurence of menopausal complaints and depressive symptoms was assessed cross-sectionally in 5896. Dutch Caucasian women of a large community sample in the city of Eindhoven the Netherlands (47.54 yrs). Menopausal complaints were assessed using a 22 items selfrating scale (consisting of a vasomotor -, uro-genital - and a cognitive / vegetative subscale), Depressive symptoms were assessed using the Edinburgh Depression 5 cale (EDS). Differences in mean scores were analysed between groups using ANONA. The independent relationship of depressive symptoms to the intensity of menopausal complaints was assessed by multiple linear regression analysis.

Results: Women using HRT showed the highist scores on all subscales.

Oral contraceptive users had significantly lower scores on the wasomotor subscale compared to HRT users and to non-users. Depressive symptoms contributed the most to the explained variance on scores on the menopausal subscales.

Conclusions: Women during menopause presenting with several complaints of other than vasomotor origin might be suffering from underlying depression which makes it questionnable to prescribe HRT for the latter symptoms. 


\section{Introduction}

According to a recent WHO report [1], depression has become a major health problem. The prevalence rate is high, the burden of illness extensive and, as a consequence, the economic costs are considerable [2]. A recent survey in the Netherlands revealed a point prevalence of 8 percent in the general population [3]. Despite the fact that treatment strategies have markedly improved, it is estimated that only $20 \%$ of depressed patients receive adequate therapy [1]. It is thought that the non-awareness of signs and symptoms of depression in the general population could partly explain the underestimation of depression as a major health problem. Moreover, in up to $50 \%$ of depressed patients who wisit their general practitioner, the symptoms are misdlagnosed [4] and therefore accurate detection should result in more appropriate therapy.

In general practice it is well known that patients presenting with various and often vague complaints may be suffering from underlying depression. Also, during menopausal transition, it is said that 50-70\% of women experience all kinds of somatic and emotional symptoms [5]. While vasomotor (flushing) and uro-genital (vaginal dryness) symptoms are widely recognised as being a direct consequence of the declining estrogen production during menopausal transition, there is much debate concerning the specificity of cognitive, vegetative and emotional symptoms in the climacteric. Nevertheless, for the latter symptoms as well, a huge amount of estrogens are prescribed (hormone replacement therapy, HRT) to relieve the inconvenience in these women. It is a matter of speculation whether women who present with a whole range of vague complaints are in fact suffering from underlying depression. If 50 , it could be questioned whether the prescription of hormone replacement therapy for these symptoms is justified.

In a large community sample of women ranging in age from $47-54$ years, we investigated the extent to which perimenopausal complaints are associated with depression.

\section{Material and methods}

\section{Subjects}

Between September 1994 and September 1995 all women $(n=8503$ ) born between 1941 and 1947 in the city of Eindhoven, the Netherlands, were invited to participate in a screening programme for osteoporosis: the Eindinoven Perimenopausal Osteoporasis Study (EPOS) [6]. A total of 6648 women (78\%) consented to participate. During the screening an accurate medical history was obtained. Subsequently, the women were asked to complete several questionnaires at home and to return these within one week after screening. 


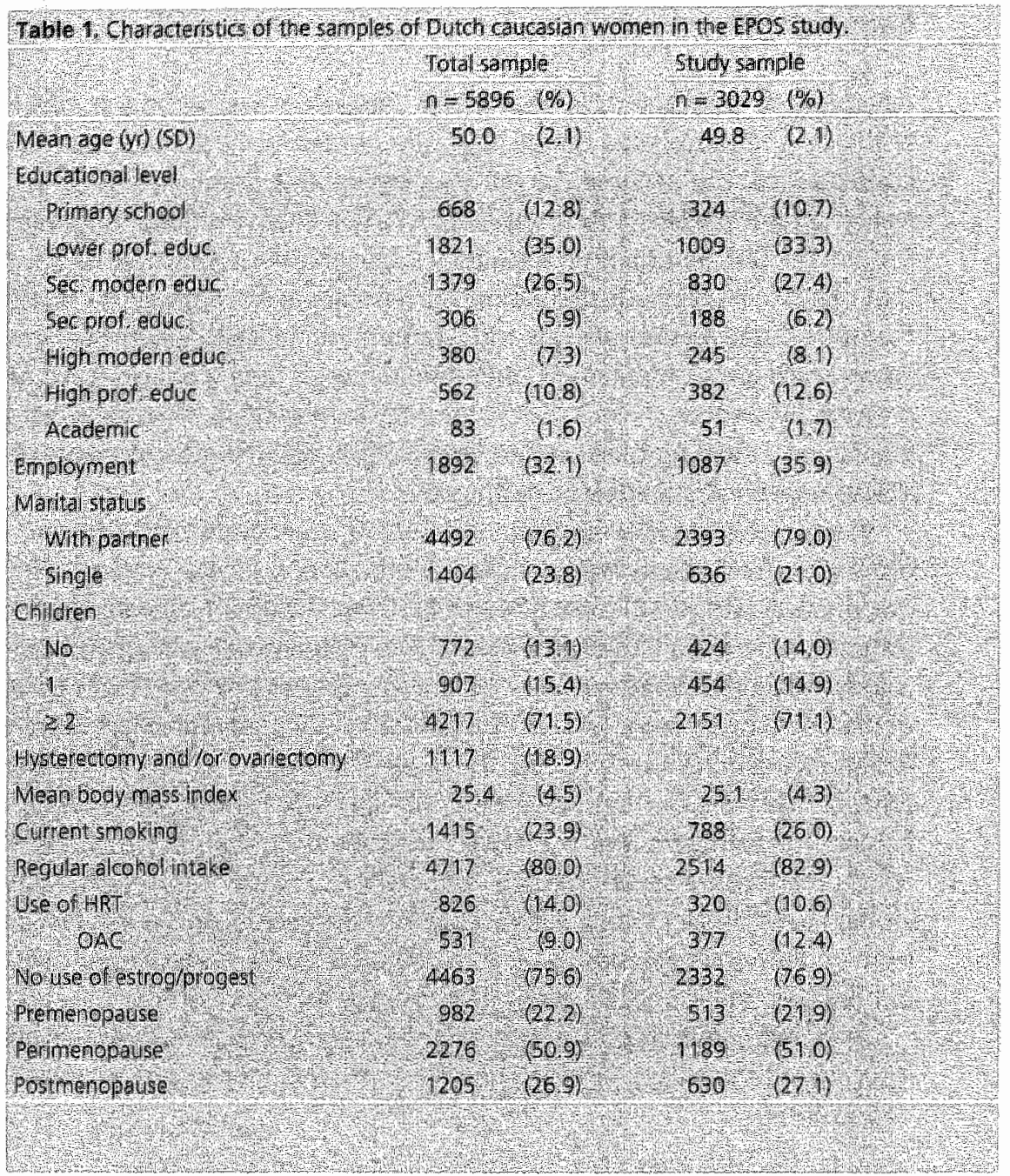

Because of possible language problems, only Dutch Caucasian women $(5896$. $89 \%$ were included in the analysis. Ninety-two percent (5424) returned the questionnaires, $76 \%$ of which (4146) were correctly completed. In onder to avoid any possible bias from gynaecological operations, all women who had undergone a hysterectomy and/or a uni- or bilateral ovariectomy $(n=1117)$ were excluded from the analysis. Therefore, the data-analysis covers the remaining 3029 women (Table 1). No differences in the characteristics were found between the original sample and the sample from this study (mean agle, educational level, employment, marital status, having had children, mean BMI and menopausal statuls.). Estrogen use was somewhat higher in the original sample ( $14 \%$ versus $10 \%)$, which was 
largely explained by the presence of ovariectomised women. Of the 3029 women. $377(12 \%)$ still used hormonal oral contraception (OC), three hundred and twenty $(10 \%)$ were on hormone replacement therapy (HRT), while 2332 women were not using any estrogen therapy.

The study was approved by the Medical Ethics Committee of the St Joseph Hospitall in Veldhoven the Netherlands.

\section{Assessment of menopausal complaints}

The occurrence of menopausal complaints was assessed using the 24 mitem self-rating scalle which has been validated earlier [7]. Moreover, we added three items: vaginal dryness, pain during intercourse and waking up at night, which, according to the literature, are also specific for the transition to menopause $[8,9]$. The psychometric properties of this 27 -item self-rating scale were analysed in the women not using any hormonal substitution $(n=2332)$. Principal Compound Factor Analysis showed that 22 items loaded significantly and covered three sub-scales: a vasomotor sub-scale (3 items: flushing, day sweating, night sweating, range 0-9), an uro-genital sub-scale (4 items: Vaginal dryness, pain with cohabitation, vaginal itching and burning on micturation, range 0.12 ) and a cognitive / vegetative sub-scale (15 items: Irritability, llack of energy, depressed mood, lack of self confidence, agitation, forgetfulness, tiredness on waking, headache, tiredness, dizzyness, muscle pain, shortness of breath, restless legs, palpitations and insomnia, range 0-45) with a Crombach's Alpha of 0.90, 0.88, and 0.65. respectively reflecting adequate internal consistency.

\section{Assessment of depressive symptoms}

Depressive symptoms were assessed using the Edinburgh Depression Scale (EDS), A 10-item self-rating scale originally designed for use in postpartum women and recently validated in middle aged non-childbearing women $[10,11,15]$. Scores vary between 0 -30 (with higher scores indicating more depressive symptomatology) with a commonly used cut-off score of 12 .

\section{Statistical Analysis}

Statistical analysis was performed using the Statistical Products and Service Solutions (SPSS). Correlations between the variouls scales were analysed by means of Pearson 's correlation coefficient (using two-tailed $p$-values). Differences in mean scores on several scalles were analysed between groups, using ANOVA. In order to detect differences between these groups, a post hoc analysis was performed using the Scheffe procedure. The independent relationship of depressive syriptoms to the intensity of menopausal complaints was assessed by multiple linear regression 
analysis, taking into account several other independent variables known from the literature to interfere with climacteric signs, such as age, body mass index, party, educational level, employment, marital status, and current smoking habits.

\section{Results}

The EDS was highly correlated to the cognitive-vegetative subscale and to a lesser degree to the vasomotor and urogenital subscales $(0.72,0.41$ and 0.37 , respectively, two tailed $p<0.0011$.

Table 2 (ANOVA) shows the differences in mean scores on the menopausal self-rating sub-scales and the EDS between women using HRT or OC and nom-users. Women using HRT showed the highest scores on all subscales. In a post hoc analysis following the Scheffe procedure, on the EDS and the cognitive/wegetative subscale, the scores of the HRT users were significantly higher than the scores of those using OC and of those of non-users. Moreover, OC users had significantly lower scores on the wasomotor subscale compared to HRT users and to mon-users. On the urogenital subscale, HRT users had higher (although not significantly) scores than the OC users and the non-users. The scores on the menopausal sub-scales in the different groups (HRT, OC and non-users) were used as dependent variables for multiple linear regression analysis, with the EDS scores and several other variables being used as independent variables (Table 3). In all groups, the EDS scores contributed the most to the explained variance on the sub-scales. Of the non-users, only postmenopausal status (no period for at least 12 months) proved to be a more important determinant of the variance of the scores on the vasomotor sub-scale.

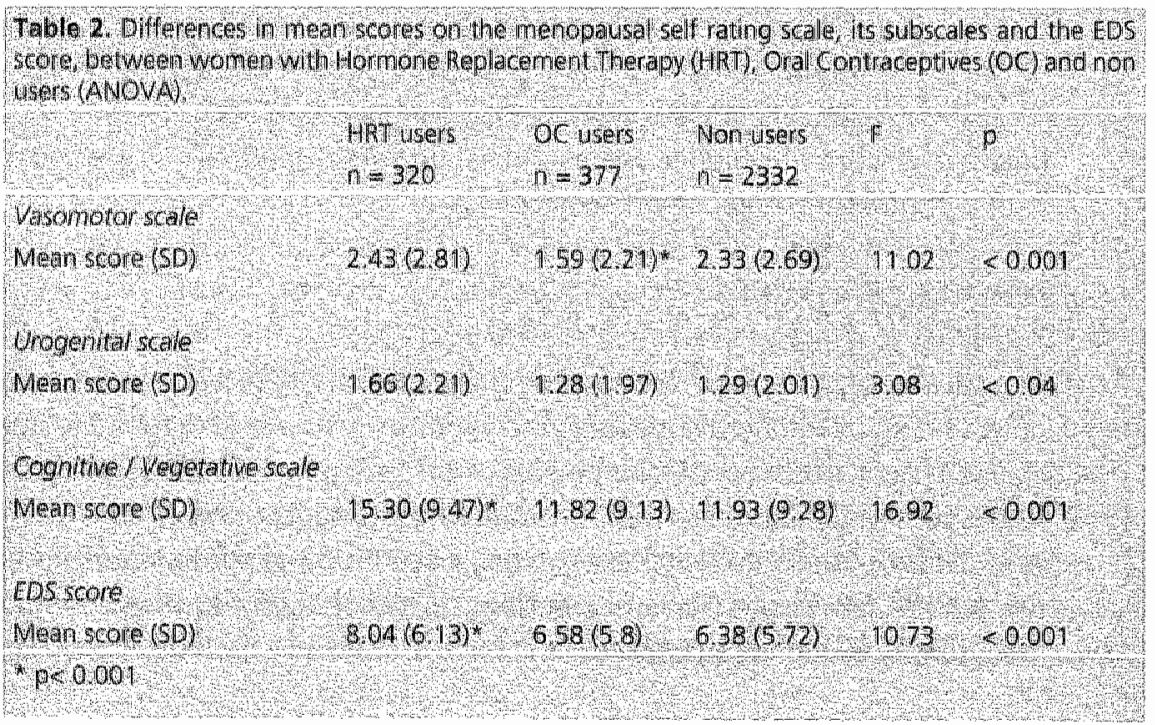




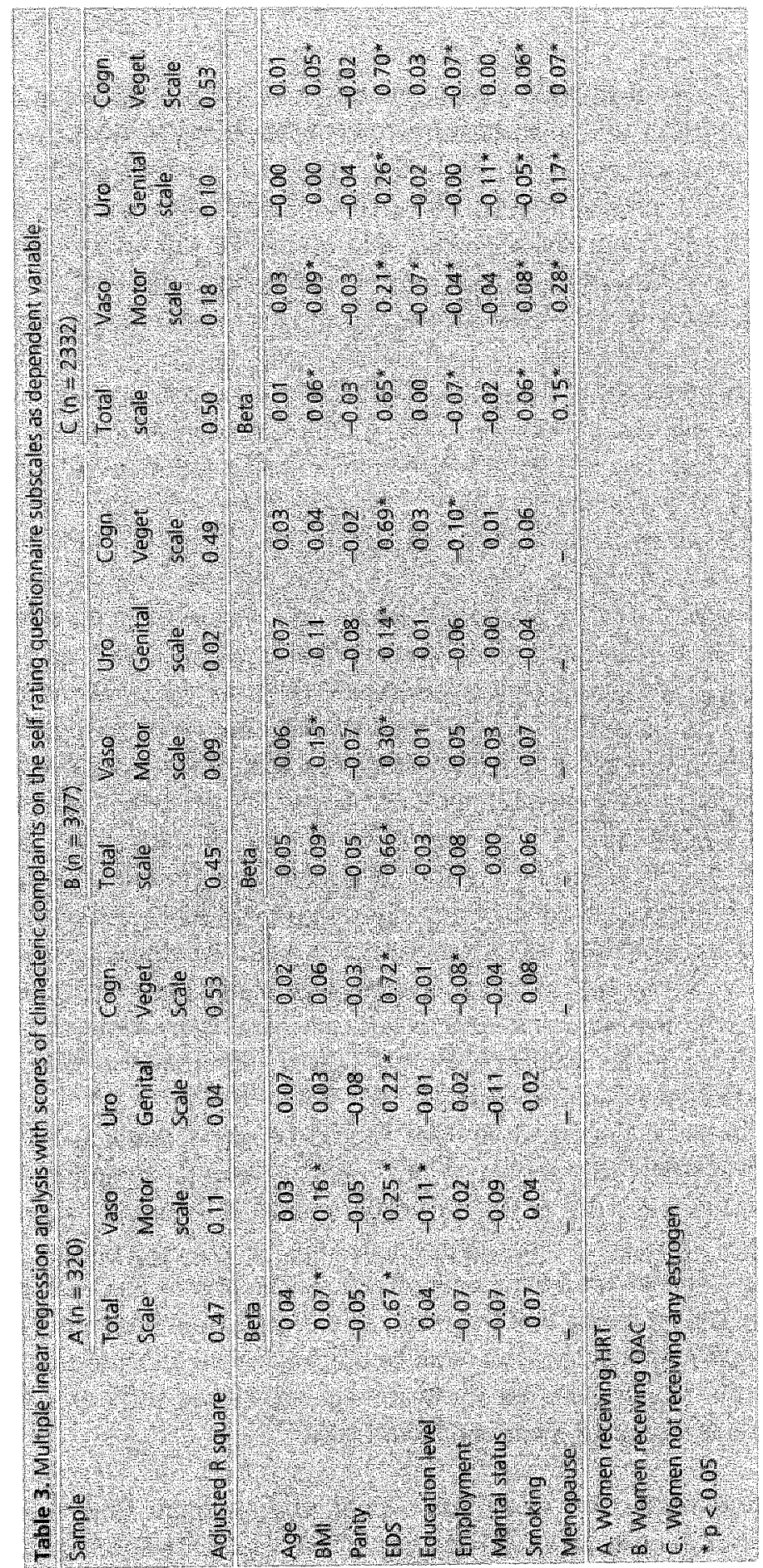




\section{Discussion}

Although, during menopausal transition, women experience many somatic and emotional symptoms, no direct correlation with the decining estrogen production has ever been demonstrated [12]. Moreover, the overall lack of clear positive findings regarding any positive effect of HRT on emotional symptoms is disappointing $[13,14]$. It is known from clinical practice that women who present with all kinds of complaints, may well be suffering from underlying depression. This paper examined the association between depression and the presentation of climacteric complaints.

Comparing cognitive and vegetative scores on a menopausal self-rating scale to scores on a depression self-rating scale (EDS) revealed a very high correlation $(0.72)$, suggesting that symptoms which are commonly regarded as being "typically" related to menopausal transition actually reflect depressive symptoma. tology. If there is any relationship between declining estrogen production and these depressive symptoms, it might be hypothesised that women taking HRT should have lower scores on the EDS than non-users. This was not the case in our study (Tabie 2): the highest scores on the EDS were recorded in HRT users. Subsequent multiple linear regression analysis (Table 3) with scores on the menopausal sulascales as the dependent variable, showed that depressive symptomatology contributed most strongly to the explained variance within all groups. Moreover, in the non-users, postmenopausal status usually contributed to high scores on the vasomotor subscale and, to a minor degree, on the urogenital subscale, but almost never to high scores on the cognitive-vegetative subscale. This suggests that declining estrogen production is indeed associated with vasomotor symptoms, whereas it has hardly any effect on cognitive and vegetative symptoms.

As far as we know, this is the first study to investiglate the correlation between depressive symptomatology and menopausall complaints (taking in to account the effect of hormone substitution) in a cohort of women representative of the female population aged between $47-54$ years.

What is the clinical relevance of these findings? Firstly, it might be suggested that, during menopausal transition, women with vasomotor symptoms benefit from HRT, whereas the use of HRT for other 'emotional' symptoms is questionable. Secondly, and even more importantly, the general practitioner who is consullted by a woman presenting with several complaints of other than of vasomotor origin, should realise that she might be suffering from underlying depression. This would hopefully lead to a more accurate diagnosis of depression and, as a consequence, to more appropriate treatment: counselling and/or the use of anti-depressants instead of a prescription for HRT.

Acknowledgements. This study was supported by a grant from the Dutch Praeventiefonds (project no. 002824010) and from the Dr. De Grood-Stichting. 


\section{References}

1. Murray, C.J.L., Lopez. A.D. (1995). "The Global Burden of Disease" Published by the Harvard School of Public Health on behalf of the World Health Organisation and the World Bank.

2. Kind, P., Sorensen, 1. (1993). The Casts of depression. Int. Clin. Psychofarmacology:7:191-195.

3. Bijl, R.V.zessen van, G., Ravelli, A. (1997). Psychiatric morbidity among adults in the Netherlands. The NEMESIS study II Prevalence of psychiatric disorders. Ned Tijolschr. Geneesk; 141: 2453-60 (in Dutch).

4. Ormel, J., Koeter, M.W., Brink, W. van den, Willige, G. wan de. (1991) Recognition, management and course of anxiety and depression in general practice. Arch Gen Psychatry: $48: 700-6$

5. Schwingl, P.J.,Hulka, B.5., Harlow, S.D. (1994). Risk factors for menopausal hot flashes Obst Gyn: $84: 29-34$.

6. Smeets Goevaers, C.G., Leusink, G.L., Papapoulos, S.E, et al. (1998). The prevalence of low mineral density in Dutch perimenopausal women: The Eindhoven Perimenopausal Osteoporosis Study Osteoporosis International;8:404-409.7. Oldenhave. A., Jaszman, I.B. Haspels, A.A., Everaerd, W.T. (1993). Impact of climacteric on weil being, Am J Obst Gyn.; 168:772-80.

8. Myra Hunter (1992). The South-East England longitudinal study of the climacteric and postmenopause Maturitas; 14:117-126.

9. Holte, A. and Mikkelsen, A. (1991) The menopausal syndrome: a factor analytic replication. Maturitas; 13:193-203.

10. Cox, J.L., Holden, J.M., Sagovsky, R. (1987), Detection of postnatal depression: Development of the 10-item Edingburgh Postnatal Depression Scale. B.J.PSych., 150:782-86.

11. Cox, J.L., Chapman, G. Murray, D., Jones, P. (1996). Validation of the Edinburgh Postnatal Depression 5cale (EPDS) in non-postnatal women. J.Aff. Dis, 39:185-89.

12. Pearlstein, T.B. (1995). Hormones and depression: What are the facts about premenstrual syndrome, menopause and homone replacement therapy? Am $f$ Obst Gyn: $173: 646-653$

13. Jane Pearce, Keith Hawton, Fiona Blake (1995). Psychological and sexual symptoms associated with the menopause and the effects of Hormone Replacement Therapy. B I Psych; 167:163-173.

14. Porter, M. Penney, G.C. Russel Eand Templeton. A. (1996). A population based survey of women's experience of the menopause. B J Obst Gyn; 103:1025-28.

15. Pop, V.J., Maartens, L.W., Leusink, G.L. Weetman, A.P. (1998). Are Auto-immune Thyroid Dysfunction and Depression related? I Clin Endocrinol. Metab.,83:3194-97. 



\section{Characteristics of perimenopausal} women using benzodiazepines

Submitted as: Maartens, L.W., Knottnerus, J.A., Leusink, G.L., Bokhoven van, M.A., Pop, V.J. Characteristics of perimenopausal women using benzodiazepines. 


\section{A B STRACT}

Objective: To investigate the extent to which benzodiazepine ( $B Z D$ ) use is associated with depression and perimenopausal complaints when taking sociodemographic characteristics, life style factors and the use of other medication into account.

Methods: The occurrence of benzodiazepine-use, menopausal complaints and depressive symptoms was assessed crossmsectionally in 5896 Dutch Caucasian women ( $47-54$ years of age) of a large community sample in the city of Eindhoven, The Netherlands. Menopausal complaints were assessed using a 27 item self-rating scale. Depressive symptoms were assessed using the Edinburgh Depression Scale (EDS). Benzodiazepinewse was defined as taking BZD on prescription in the two weeks before completing the questionnaires.

Results: BZD users showed significant differences in: EDS scores $>12(51 \%$ versus $19 \%)$, educational level, divorce, daily alcohol use $(31.3 \%$ wersus $19.5 \%)$, current smoking $(37.7 \%$ versus $23.7 \%)$, use of several medications, menopausal complaints, hysterectomies and/or ovariectomies, and one-child families. In multiple logistic regression analysis, smoking $(O R=1.7)$, estrogen use $(O R=1.5)$ and depression score $(O R=4.6)$ were significant determinants of $\mathrm{BZD}$ use. Increasing depression scores were significantly associated with the Use of BZD and other kinds of medication such as antidepressants, painkillers, gastric medication and estrogens.

Conclusions: The health status of permenopausal women using BZD is worrying for several reasons. Depression score is the main determinant of BZD use. High drug intake and poor life style habits are significantly more Common in $B Z D$ users. We hypothesize that the recognition and appropriate treatment of depression will contribute to a decreased BZD use and to an improvement in the physical, mental and social functioning of these women. 


\section{Introduction}

Benzodiazepines (BZD) are among the most widely prescribed drugs in general practice [1, 21. Several large general population surveys in Europe have shown the prevalence rate of benzodiazepine use in women aged $45-65$ years to be approximately $12 \%[3,4]$. The prescribing of BZD covers a number of major medical indications: insomnia, muscular spasms, epilepsy, anxiety and preoperative medication. Simon et all. found that, among primary care patients receiving new prescriptions for BZD, insomnia and non-specific physical complaints accounted for the majority of prescriptions, while psychological symptoms accounted for onlly one quarter of total new BZD prescriptions [5]. In a large population survey. Olfsen and Pincus found a high correlation between BZD and antidepressant use [6]. Studies addressing the health characteristics of BZD users have all shown relatively high scores of physical morbidity in users of psychotropic medication in general and BZD users in particular $[7,8]$. Surveys of general medical practice confirm that psychotropic medications are commonly prescribed in the absence of a mental disorder diagnosis [9]. In a general population survey in Great Brittain, the male / female ratio for taking $B Z D$ was $1: 2$ [3]. A Dutch national survey into general practice showed that women aged $45-64$ years received a first prescription for BZD almost twice as often as men of similar age, without symptoms or diagnosis being an indication [4]. In the age range of the menopausal transition, women experience all kinds of physical and emotional symptoms. It has also been reported that women presenting with various and often vague complaints around the menopause may be suffering from underlying depression [10]. In up to $50 \%$ of depressed patients who visit their GP these symptoms are misinterpreted [11-13]. Accordingly, prescription of $\mathrm{BZD}$ may be used to treat women presenting with a whole range of vague complaints, who are in fact suffering from depression. If so, it could be questioned whether the prescription of BZD is justified for these symptoms.

In a large community sample of women ranging in age from 47 to 54 , years we investigated the extent to which BZD use is associated with depression and perimenopausal complaints, taking into account sociodemographic characteristics, life style factors and the use of other medication.

\section{Materiais and Methods}

\section{Subjects}

Between September 1994 and September 1995, all women born between 1941 and 1947 and living in the city of Eindhoven, the Netheriands, were invited to participate in a screening programme for osteoporosis: The Eindhoven 
Perimenopausal Osteoporosis Study (EPOS) [18]. A total of 6648 women (78\%) consented to participate. During the screening, a medical history was obtained. Subsequently the women were asked to complete several questionnaires at home and to return these within one week after screening. Because of possible language problems, only Dutch (Caucasian) women were included in the analysis. The data analysis refers to the 4146 women $(76 \%)$ who correctly completed the questionnaires.

\section{Benzodiazepine use}

The participants completed questions concerning their medication. BZD use was defined as taking BZD on prescription in the 2 weeks before completing the questionnaire.

\section{Assessment of menopausal complaints}

The occurrence of menopausal complain's was assessed using a validated 27 -item selfrating scale with a four point score per item (0-3, range of sum score 0-81. We used a cut-off score of 50, being one standard deviation above the mean) [14]. The psychometric properties of this self-rating scale were analysed in women not using any hormonal substitution.

\section{Assessment of depressive symptoms}

Depressive symptoms were assessed using the Edinburgh Depression Scale (EDS), a 10 item self-rating scale $[15,16]$. (Range of sum score 0-30 with higher scores indicating more depressive symptomatology) with a commonly used cut-off scone of $>12$ for minor depression and $>14$ for major depression. Recently, the EDS has been validated in non child bearing, middle-aged women [20].

\section{Statistical analysis}

Statistical analysis was performed using the statistical Products and Service Solutions (SPSS). Differences between proportions were tested with the chi square test for independent samples. If the expected number of obserwations in at least one cell was five or less, the fisher exact test was used. T test was performed to assess the differences in depression score (EDS) and menopausal complaints between BZD users and non-users. In a multiple logistic regression analysis with BZD use as the dependent variable, the simultaneous influence of the EDS score and covariables was evaluated and expressed in adjusted odds ratios with $95 \%$ confidence intervals. The chi square test for trend was used to evaluate trends in proportions over the categories in the EDS scale. 


\section{Results}

Benzadiazepines were used by $7.6 \%$ of the total sample of perimenopausal women in our survey. The BZD users differed from non-users in several ways (Table 1). More $B Z D$ users were divorced, and had undergone hysterectomy and ovariectomy more frequently than non-users. BZD users had a lower educational level: more women with only primary school education and less women with higher professional education used BZD. The daily use of alcohol was more frequent in $B Z D$ users than in non users $(31.3 \%$ versus $19.5 \%$ ). Howewer, there was no difference between BZD users and non-users with regard to alcohol use less than once a week. Current smoking was more frequent in BZD users than in non-users (37.7 versus 23.7\%). Large differences between BZD users and non-users were found regarding the use of other medication. BZD users used almost seven times the amoumt of anti-depressants compared to non-users (13.3\% versus. $2.0 \%$ ). Moreover the use of gastric medication, painkillers and estrogens was markedly higher in BZD users. We noted $51 \%$ of BZD users with an EDS score of $>12$, while in the non-users, only $19 \%$ met this criterion. BZD users had more menopausal complaints than non-users. No difference in age between BZD users and non-users was found. In order to evaluate the relationship between BZD use, depression score, perimenopausal complaints and several other covariables, a multiple logistic regression analysis with $B Z D$ use as the dependent variable was performed. Estrogen use, smoking and depression score showed odds ratios of $1.5,1.7$ and 4.6 , respectively ( $p<0.05$, Table 2). Since the EDS score was related to BZD use, and given the fact that BZD use in itself is correlated with a higher consumption of anti-depressants and other kinds of medication (Table 1), we investigated the use of several medications in relation to advancing degrees of severity of the EDS score (Table 3). The use of antidepressants and of BZDS clearly increased with an increasing EDS score. Less prominent increases were seen with the use of painkillers, estrogens and gastric medication. In the subgroup $(n=708$ ) with an EDS score $>14$ (indicating major depression), $8 \%$ of the subjects used antidepressants.

\section{Discussion}

In our survey, we assessed BZD use in women in the perimenopausal age range. We found a prevalence of BZD use of $7.6 \%$. Perimenopausal women present with "typical" vasomotor and urogenital complaints and also experience all kinds of other, less specific, somatic and emotional symptoms [17]. We considered that, presenting with these symptoms in general practice, women around the menopause might be more vulnerable to the prescription and use of BZD. This hypothesis seems to have been confirmed, for, according to a self-rating scale, $31.1 \%$ of all BZD users presented with more than average menopausal complaints, 
Table 1 . characteristics of the sample of Dutch Caucasian perimenopausd women $(4754$ yr) $n=4146$

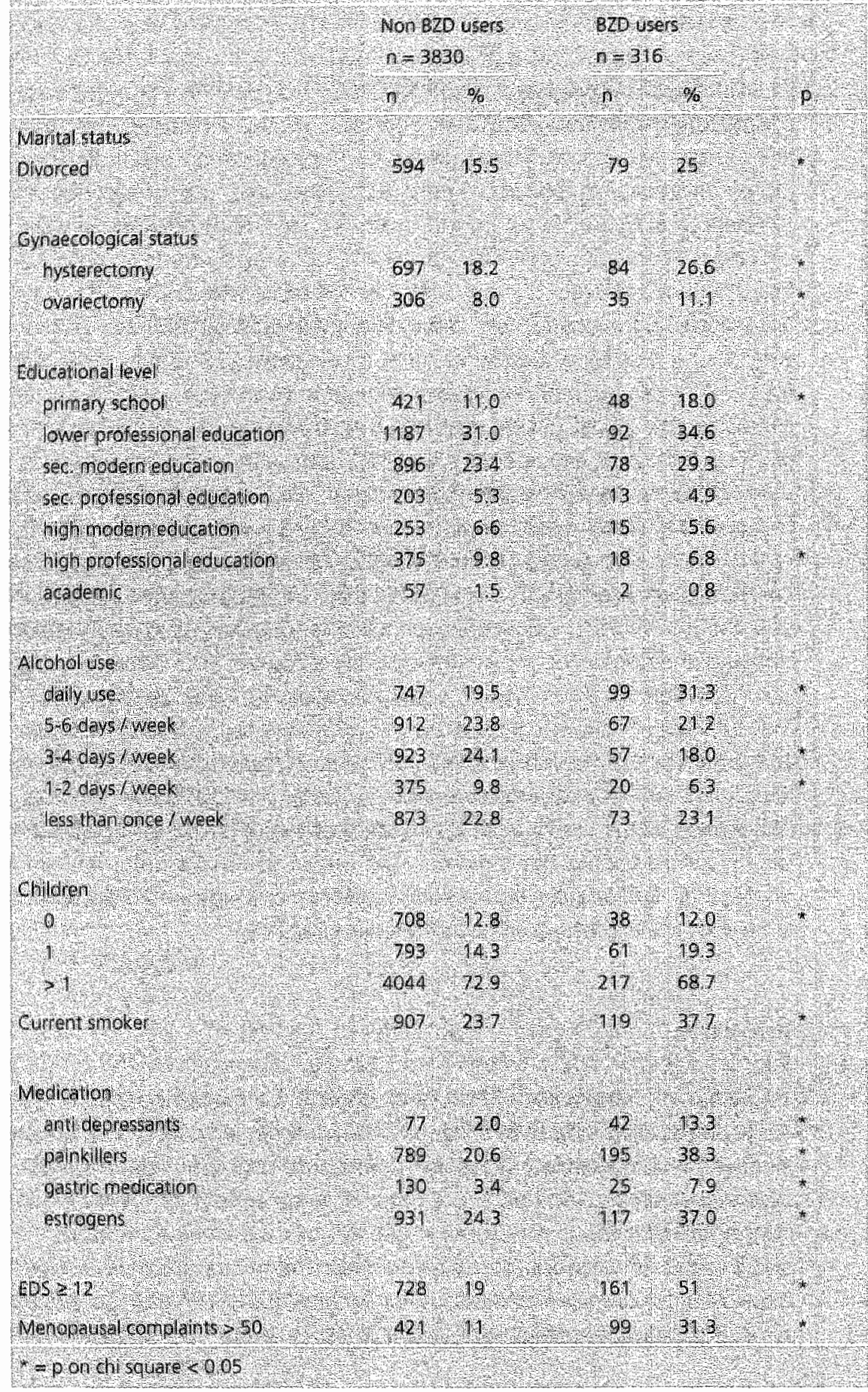




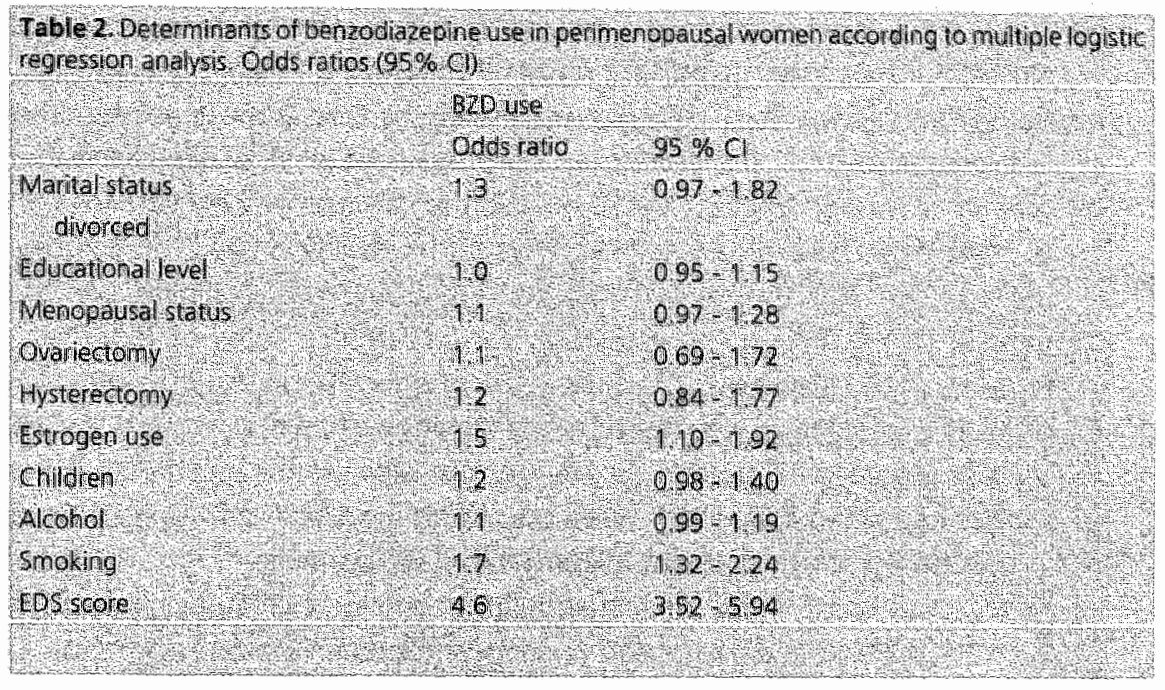

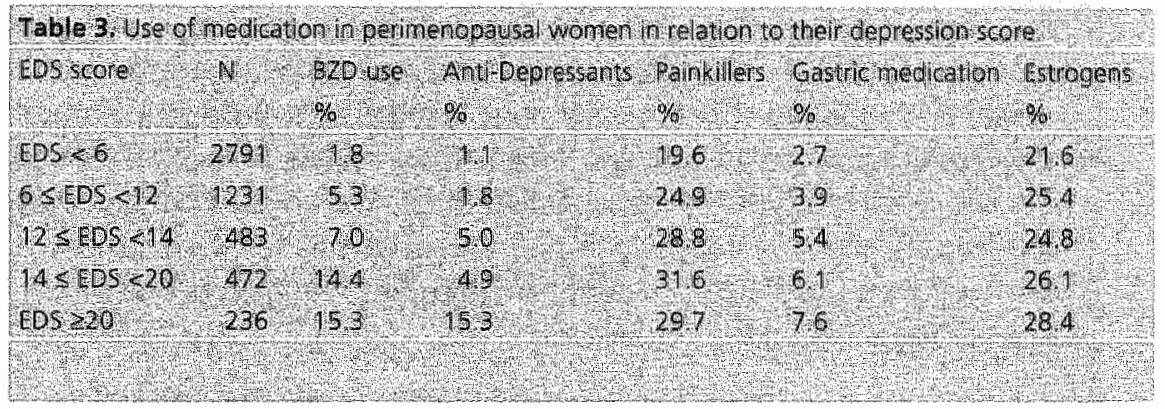

compared to only $11 \%$ of non-users. An earlier study of the same population revealed a clear relationship between perimenopausal complaints and depression [10]. In our current survey, we found significantly more BZD users among women with a higher EDS score. We also demonstrated a strong positive relationship between BZD use and EDS score when taking other covariables into account. Perimenopausal complaints were not used as independent variables in the analysis, because of the high correlation with the EDS score [10]. These results suggest that depression might be a risk factor for BZD use, while it is unlikely that BZD use will lead to depression. We also found several other significant differences between BZD users and non-users. According to life style factors, almost one in every three BZD users was a daily alcohol user and almost $38 \%$ were current smokers. From a socio-demographic point of vieum, users were more often divorced and had a lower educational leve!. With regard to their gynaecologica! status, BZD users more frequently underwent hysterectomy and/or ovariectomy. 
Apart from BZD, users took significantly more amounts of other medications: almost twice as many painkillers, more than double the quantity of gastric medications, one and a half times more estrogens and almost seven times more anti-depressants. In the literature, the prevalence of BZD use is reported to be greater in women than in men $[3,4]$. Women are also much more likely than men to have depressive disorders [19]. Physical morbidity is seen more often in BZD users $[7,8]$, and the rate of $B Z D$ use increases with declining perceptions of general health [6]. In the literature, the prevalence rates of BZD use vary. In females, in the age group of $45-54$ years of age, Dunbar found a prevalence rate of $12.9 \%$, which seerns to be considerably higher than that in our study. However, Dunbar reported BZD use as a past-year prevalence rate and half the users in his sample had taken BZD in the week preceding the survey [3]. We assessed BZD use in the two weeks prior to completing the questionnaire.

As far as we know, this is the first population-based survey studying the relationship between $B Z D$ use and depression in a narrow (perimenopausal) age range. Only one earlier population based study concerning BZD use and depression has been carried out, but this concerned both men and women aged over 18 years [6] and therefore our study is unique in its focus on BZD use and depression in perimenopausal women. Most of the time, depression is not recognized or treated adequately. It might be suggested that the treatment of depressed patients with appropriate agents will contribute to an improvement in their physical, mental and social functioning. Since much of the management of depression occurs in general practice, approaches aimed at recognition and adequate treatment could play a role in decreasing the use of BZD and polypharmaceutical treatment and, at the same time, in lessening the burden of depression.

\section{Conclusions}

Our survey shows that the health status of perimenopausal women using BZDs is worrying. Medical problems such as high drug intake, depression and BZD use seem to build up in this group. Half the women are depressed and, due to their smoking and use of alcohol, they often have unhealthy life style habits. The timely recognition and adequate treatment of depression may reduce $B Z D$ and other drug use as well as the burden of depression.

Acknowledgements. This study was supported by a grant from the Dutch Praeventiefonds (project No. 002824010) and the Dr. De Grood Stichting. We would like to thank P. van Nierop epidemiologist with the Municipal Public Health Services, Eindhoven for his help in the recruitment of the participants. 


\section{References}

1. Hulten van, R. (1998). Thesis: Studies of bemzodiazepine use in a Dutch community. Utrecht 15BN 906526048

2. Kirby, M., Denihan, A., Bruce, 1., Radic, A. "Coakley, D., Lawlor, B.A. (1999), Benzodiaz" epine use among elderly in the community. Int J Geriatr Psychiat; 4280-4.

3. Dunbar, G., Perera, M., Jenner, F. (1989). Patterns of benzodiazepine use in Great Britain as measured by a general population surwey , Br J Psychiat" $155.836-41$.

4. Waals van der, F., Mohrs, J., Foets, M. (1993). Sex differences among recipients of benzodiazepines in Dutch general practice. BM, 307:363-6.

5. Simon, G. Vonkorff, M., Barlow, W., Pabiniak, C., Wagner, E. (1996). Predictors of chronic benzodiazepine use in a health maintainance organization sample. I Cin Epidemiol: 49:1067-73.

6. Olfsen, M. Pincus, H. (1994). Use of benzodiazepines in the community. Arch intern Med; 154:1235-40

7. Simpson, R., Power, K., Wallace, L., Butcher, M., Swanson, V., Simpson, E. (1990) Controlled comparison of the characteristics of long term benzodiazepine users in general practice. Br 1 Gen Pract:40:22-6.

8. Mant, A., Mattick, R., De Burgh, 5. Donelly, N., Hall, W. (1995). Benzodiazepine prescribing in general practice: dispelling some myths. Fam Pract; 12:37-43.

9. Jencks. S.F. (1985). Recognition of mental distress and diagnosis of mental disorder in primary care. /AMA;253:1903-07.

10. Maartens, L.W., Leusink, G.L., Knottnerus, J.A., Pop, V.J. (2000). Hormonal substitution during menopause: What are we treating? Maturitas;34(2):113-18.

11. Freeling, P., Rao, B.M., Paykel, E.S., Sirelling, L. Burton, R. (1985). Unrecognised depression in general practice. BM;290:1880-1883.

12. Bridges, K., Goldberg, D. (1987). Somatic presentation of depressive illness in primary Care. In: Freeling P, Downey L, Malkin J eds, The Presentation of Depression: Current Approaches. London, UK: Royal College of Practitioners.

13. Tiemans, B., Ormel, J., Simon, G. (1996), Occurence, recognition and outcome of psychological disorders in primary care. Am J Psychiat, 153:636-44

14. Oldenhave, A. Jaszman, 1., Haspels, A., Everaerd, W. (1993). Impact of climacteric on well being. Am J Obstet Gynecol, 168:772-80.

15. Cox, J., Holden, J., Sagovsky, R. (1987). Detection of postnatal depression: development of the 10-item Edinburgh Postnatal Depression Scale.; BJ Psych.; 150:782-86.

16. Cox, J., Chapman, G., Murray, D., Jones, P. (1996). Validation of the Edinburgh Postnatal Depression Scale (EPDS) in non-postnatal women. J Aff Disorders;39:185-89

17. Schwingl, P., Hulka, B., Harlow, 5. (1994). Risk factors for menopausal hot flashes. Obstet Gynecol:34:29-34.

18. Smeets Goevaers, C., Leusink, G. Papapoulos, S., Maartens, L., Keyzer, J., Weerdenburg, I. Beyers, L., Zwinderman, A, Knotnerus, J.A, Pols, H., Pop, W. (1998). The prevalence of low bone mineral density in Dutch perimenopausal women. Osteoporosis int:8:404-09.

19. Williams, J., Spitzer, R. Linzer, M. Kroenke, K., Hahr, S., Verloin deGruy, F., Lazev, A. (1995). Gender differences in depression in primarycare. Am J Obster Gynecol, 173.654-9.

20. Pop. W.J., Maartens, L.W. Leusink, G.L. Weetman, A.P. (1998), Are Auto-immune thyroid dysfunction and depression related? J Clim Endocrinol Metab;83:3194-97. 

Menopausal transition and increased depressive symptomatology:

\section{A community based prospective study}

Submitted as: Maartens, L.W., Knottmerus, J.A., Pop, V.J. Menopausal transition and increased depressive symptomatology: A community based prospective study. 


\section{A B STRACT}

Context: Prevalence of depression is suggested to be substantially higher in women around menopause. Dedining estrogen levels might be an explanation.

Objective: This study attempits to determine whether depressive symptomatology in healthy women is independently related to menopausal transition.

Design: A large cohort of women was followed during 3.5 years (SD 0.4). Depressive symptomatology was assessed using the Edinburgh Depression Scalle (EDS). Independent relationship between an intra- individual change in EDS score during the follow-up period and menopausal transition was analysed. Setting: This study was a longitudinal follow up of a large randomly sampled population based cohort of women around menopause. Participants: All caucasian women born between 1941 and 1947, living in the city of Eindhoven the Netherlands were invited to take part in a screening program ( $n=8098$ ) of whom $78 \%$ participated $(n=6648)$. $92 \%$ retumed the questionnaires of which $81 \%(n=4975)$ was fully completed. Women using estrogens and/or having undergone hysterectomy and/or ovariectomy were excluded ( $43.6 \%$ ). Of the remaining 2820 women, after 3.5 years, 2748 returned another postal questionnaire, of which $76 \%$ was fully completed $(n=2103$ ).

Results: Beside the classical determinants of depression (unemployment $O R$ 3.1. CI 1.6-5.8, inability to work OR 1.7, CI 1.0-2.8, financial problems $O R$ $2.9 . \mathrm{CI} 1.1-7.3$ death of a partner OR $2.6, \mathrm{Cl} 1.1-6.1$, death of a child $O R$ 5.9. CI 1.1-3.2.1 and a previous episode of depression OR 2.0. (1 1.5-2.7) transition from peri- to postmenopause was significantly related to a high increase ( $>5.4$ ) of the EDS score (OR 1.8, CI 1.5-2.7).

Conclusion: Only the transition from peri- to postmenopause seems to be independently related to a high increase of depressive symptomatology. This suggests that the complete ceasing of ovarian estrogen production rather than declining estrogen levells is a risk factor for depressive symptomatology. 


\section{Introduction}

Psychological and somatic symptoms presented by women in middle life are frequently attributed to the menopause. Moreover, patients in general, with various and often vague complaints, may be suffering from underlying depression [1]. It has been suggested that, during the menopausal transition, the prevaience of depression in women is substantially higher compared to other phases of life, possibly due to changing hormone levels during menopausal transition [2] Besides hormonal changes, other factors are thought to interact with depression. such as employment state and marital status, the occurrence of major life events, and a previous episode of depression [3-5]. Unti] now it has not been clear how these factors are interrelated. However, a large meta-analysis did not support the hypothesis of a relationship between declining estrogen levels and depression, which might very well be explained by a poor definition of depression and menopausal status, and the use of small and biased samples (see for example, Nicol Smith [6]).

In order to determine causal relationships in time, a longitudinal design is needed. Only a few studies have used this design [ [ $\left.\begin{array}{llll}2 & 5 & 7 & 8\end{array}\right]$ showing that psychosocial factors increase the risk of depressive symptomatology during menopausal transition, rather than declining estrogen levels. A major shortcoming of these reports is the inclusion of women using HRT and women who have undergone hysterectomy. It has been suggested that these women are especially at risk for depression [1]. The current study attempts to determine whether there is an individual change in depressive symptomatology during menopausal transition among a large community sample of healthy women not using HRT and not having undergone hysterectomy, taking into account demographic and psychosocial factors which are known to be related to depression.

\section{Methods}

\section{Subjects}

The study was carried out in the context of the Eindhoven Perimenopausal Osteoporosis Study (EPOS) [9]. The first part of the study was a cross-sectional population survey. Between September 1994 and September 1995 (T1), all women living in the city of Eindhoven, the Netherlands, and born between 1941 and 1947 $(n=8503)$, were invited to participate in a large screening program to assess bone mineral density(BMD). At the first visit for $B M D$ screening, demographic features and detailed menstrual, gynecological and general medical history were obtained by paramedical assistants. Subsequently, the participants were asked to complete several questionnaires at home and to return these within one week. For reasons 
of methodology (language problems in using self-rating scales) and in order to obtain homogeneous data, the analysis included only Dutch Caucasian women $(n=8098)$, of whom $6648(78 \%)$ participated in the study. Six thousand one hundred and sixteen women $(92 \%)$ returned the questionnaires, $4975(81 \%)$ of whom correctly completed the self-rating scales. Cross-sectional data analysis failed to show a relationship between depression and menopausal status [3].

The prospective part of the EPOS study consists of the longitudinal follow-up of women from the baseline sample at T1. In 1998 (T2), after a mean period of 3.5 years $(S D=0.4$ ) with al range of 2.8 and 4.7 years, 2748 women not using HRT and not having undergone hysterectomy and/or ovariectomy were invited to complete a postal questionnaire assessing depression. Eighty percent of these women returned the questionnaires $(n=2207), 2103(76 \%)$ of which were fully completed. Therefore, the data analysis refers to these 2103 women.

\section{Definition of depression}

Depressive symptomatology was assessed using the Edinburgh Depression Scale. (EDS) at both $T 1$ and T2. The EDS was originally developed for use in post-natal women (EPDS) [10]. The scores vary from 0 to 30 (higher scores indicating more depressive symptomatology) and a commonly used cut-off score of 11 has been proven to have high specifity and sensitivity in assessing depression. The EPDS has also been vallidated for use in non-childbearing women, and recently for use in menopausal women [11, 12].

\section{Definition of menopausal state}

Menopausal status was determined, distinguishing between pre-, peri- and post-menopausal states. Premenopausal staus was defined as an unchanged menstrual pattern; perimenopausal refers to an irregular menstrual pattern with at least one menstrual period in the preceding 12 months; postmenopausal status is amenorhea for at least one year. By definition, women using estrogens and/or progestagens were not included, nor were women with an artificial menopause due to hysterectomy and/or bilateral ovariectomy.

\section{Statistical analysis}

Statistical analysis was performed using the Statistical Products and Service Solutions (SPSS). Transition from T1 to T2 was subdivided into six different groups: women in whom the menopausal status had not changed (pre-pre, peri-peri and post-post), and women who had gone through different menopausal statuses (pre-peri, pre-post and peri-post). The change in mean EDS scores between $T 1$ and 
T2, for each transition group, was evaluated using paired samples t tests (wwotalled).

Subsequently, the independent relationship between menopausal transition (independent variable) and the intra-individual change in EDS score (dependent variable) was analysed by multiple logistic regression analysis, taking into acount other independent variables, such as: demographic variables (age, marital status, employment), the occurrence of major life events, and a previous episode of depression. Moreover, the time interval between T1 and T2 was also used as an independent variable.

\section{Results}

Table 1 shows the mean EDS scores of 2103 women at T1 and T2 in relation to menopausal transition. At $T 2$, the mean increase in age was 3.5 years (range, 2.8 -4.7 years.) During the interval between $T 1$ and $T 2$, the number of women with prem or perimenopausal status decreased by $50 \%$, and the number of postmenopausal women doubled (Table 1). The total percentage of women with depression (EDS score $\geq 12$ ) at T1 and $T 2$ was $18.5 \%$ and $23.7 \%$, respectively. The mean EDS score at T1 was lowest in premenopause (5.6) and was higher in peri (6.5) and post-menopause (7.8). This was also the case at T2 (EDS in premenopause $=6.8$, peri $=7.0$, and postmenopause $=7.7)$. in the total sample. the mean difference in EDS score between T1 and T2 was 0.7 (SD 5.0, p<0.001, paired sample $t$ test). Table 2 shows the changes in mean EDS scores in the different transition groups. One hundred and seventy-three women still had a regular menstruation period at $T 2$, while almost one-third had changed from perito postmenopause. Only $4 \%$ of the women $(n=90)$ showed a transition from regular menstruation to amenorhea of at least 12 months within the follow-up period. Excluding those women who were already postmenopausal at 71 , there was an increase in mean EDS scores in all other transition groups. The highest

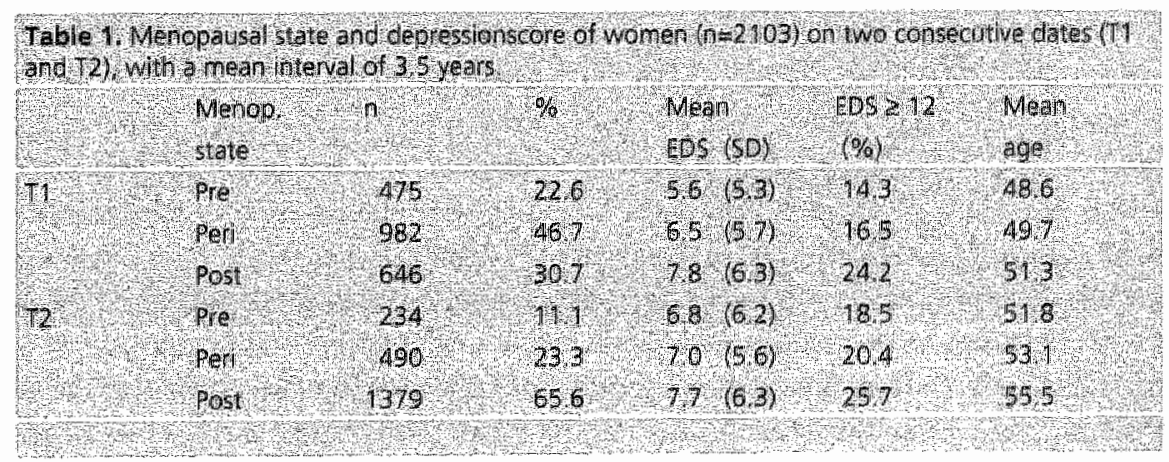




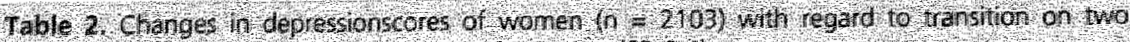

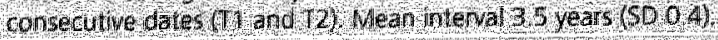

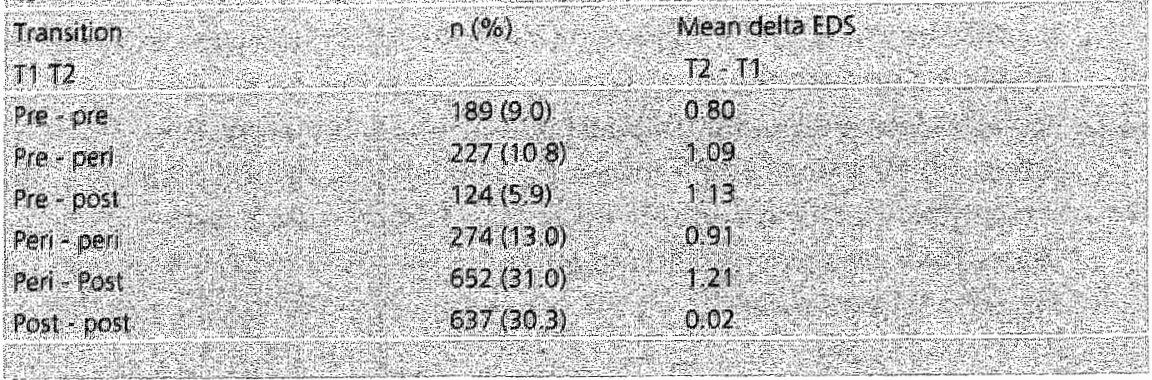

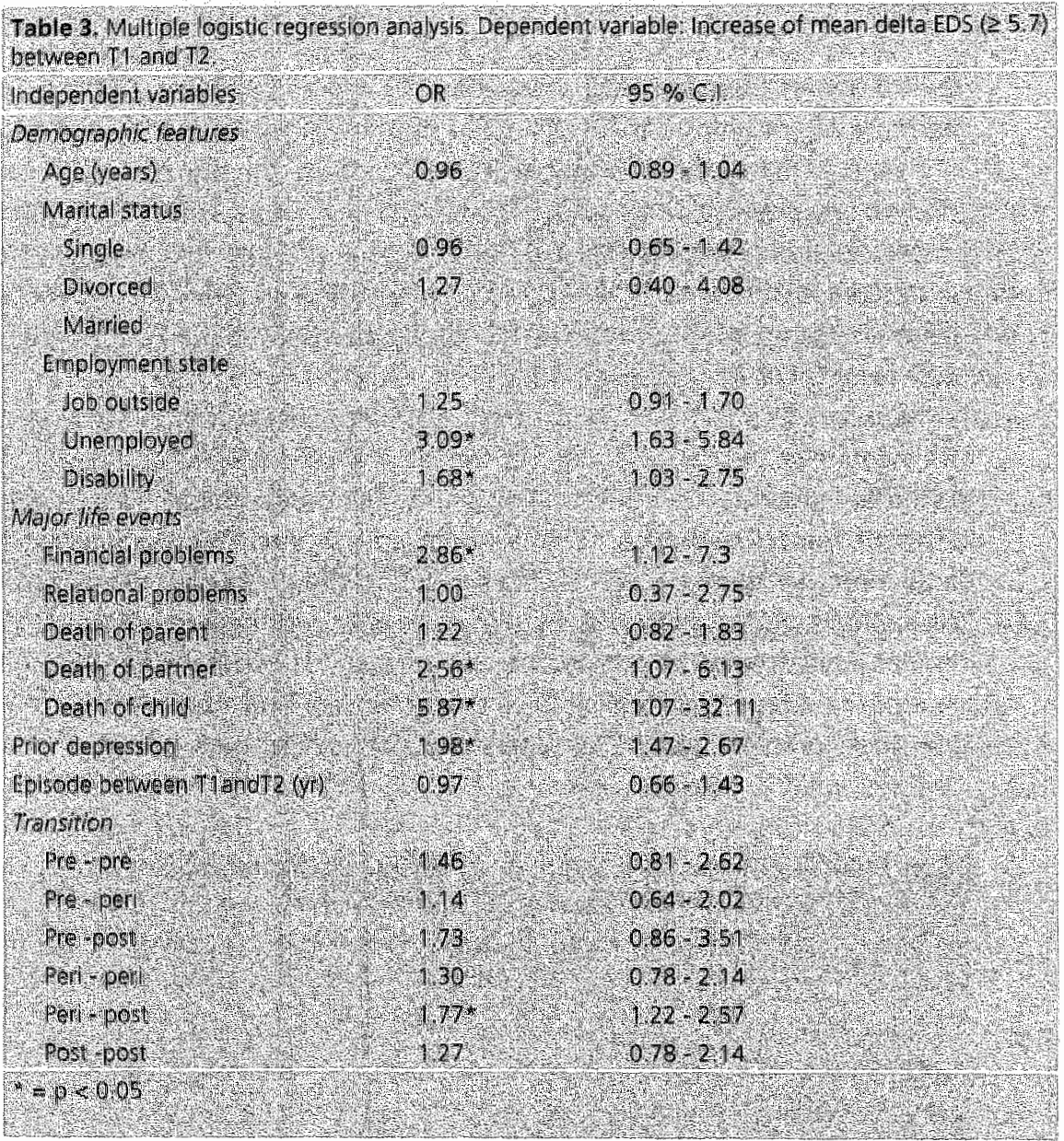


increase in mean EDS scores $(=1.2)$ was found during the transition from peri- to postmenopause. In order to investigate independent determinants which might explain the change in the EDS scores between $T 1$ and $T 2$, multiple logistic regression analysis was performed (Table 3 ). The dependent variable was a high increase in EDS score, defined as an increase of more than one SD (5.0) above the mean change (0.7) in the whole as a group. The different transition groups, as well as the time interval between $\mathrm{T} 1$ and $\mathrm{T} 2$ and several psychosocial determinants, were entered into the analysis as independent variables. It was found that only the transition from peri- to postmenopause was significantly related to a high increase in the EDS score (OR $1.8,95 \% \mathrm{Cl}: 1.2-2.6)$. Other independent factors which were significantly related to a high increase in the EDS scores were a previous episode of depression (OR 2.0, 95\% Cl: 1.5-2.7), unemployment (OR 3.1, 95\% Cl: 1.6-5.8) an inability to work outside the home (OR $1.7,95 \% \mathrm{Cl}: 1.1-2.8)$, as well as the occurrence of a major life event between $T 1$ and $T 2$ (OR $3.4,95 \% \mathrm{Cl}: 1.9 \cdot 6.2$ ).

\section{Discussion}

As far as we know, this is the first longitudinal follow-up study of a large cohort of women proceeding through natural menopause (excluding women on HRT and oral contraceptives and women having undergone hysterectomy and/or bilateral ovariectomy), in whom the occurrence of depressive symptoms was investiglated. The number of women with depression (EDS $\geq 12$ ), as well as the mean EDS scores in the total group, increased during follow-up. Using multiple logistic regression analysis, only the transition from peri- to postmenopause showed an independent relation to a high increase of depressive symptoms (OR $1.8,95 \% \mathrm{Cl} 1.2-2.6)$. Several cross-sectional studies - studying differences in the prevalence of depression between women with different menopausal status - also found the highest prevalence rate of depression to be in postmenopausal women, which was also the case in an analysis of the cross-sectional data of the Eindhoven Perimenopausal Study $[3,4]$. In general, it is accepted that, with increasing age, the prevalence of depression also increases. However, the maximum range of 4.7 years between the two assessments is unlikely to explain the observed increase of depression in this sample. Therefore, it is reasonable to hypothesize that menopausal transition itself might contribute to a higher prevalence-rate of depression. However, our cross-sectional data as well as that of others failed to find an independent relationship between depression and menopausal status [3, 13]. In the current longitudinal study, women who went from peri- to postmenopausal status had an aimost two-fold increased risk of a high increase of depressive symptoms. This suggests that the end of ovarian estrogen production, as reflected by an amonorrhea of 12 months or more, might be an independent risk factor for depression. It has been shown that estrogen is capable of modulating serotonergic 
function in the central nervous system [14]. Several models have been proposed to explain estrogen-Serotonine interaction, suggesting an increased vulnerability to affective disorders in women with hormonal changes during the female life cycle. Several limitations of the current study should be mentioned. Measuring depressive symptomatology is not the same as assessing a syndromal diagnosis of depression. However, the EDS, using a cut-off score of $\geq 12$, has been shown to detect up to $60 \%$ of women with major depression [12]. Moreover, having high scores of depressive symptoms is by far the strongest predictor of depression. Besides, other independent factors which have not been taken into account, could explain the increase of depression. For instance, thyroid immune disease has been demonstrated to be an independent risk factor for depression in menopausal women, the incidence of which increases with age [3].

So far, only a few studies have inwestigated the relationship between menopausal transition and depression, using a longitudinal design. In the Massachusetts Women's Health Study [7] (in which HRT users were not excluded), only the experience of a long perimenopausal period of at least 27 months was associated with an increased risk of depression. The explanation for this phenomenon was thought to be the relationship between a long period of menopausal transition and the subsequent increase of menopausal symptoms increasing the vulnerability to depression. However, in an earlier study [1], an inverse relationship was shown between depression and menopausal complaints: Women with high depressive symptomatology were the most vulnerable to a high intensity of menopausal complaints, suggesting that the reporting of menopausal symptoms is a consequence rather than a cause of underlying depression. In another longitudinal study, the Manitoba Project [2], the only gynaecological characteristic that showed any relation to depression was hysterectomy. The explanation given was not hysterectomy per se, but rather that women with clinical depression tended to be more prone to surgery [15]. The South-East England longitudinal study [5] is the only survey to show that women in the peripostmenopause are more frequently depressed compared to premenopausal women. However, the sample was very small $(n=36)$ and the women were recruited from a population attending a routine ovarian screening clinic. In addition to these earlier findings, the results of our study suggest that a subgroup of women during menopausal transition might benefit from estrogen substitution, as far as affective disorders are concerned. Before this strategy can be advocated, placebo-controlled and double-blinded clinical trials, with sufficient epidemiological power, in women not recruited from menopausal clinics, are needed in order to evaluate the effectiveness of estrogen substitution.

\section{Acknowledgements}

This study was supported by a grant from the Dutch Praeventiefonds (project no. 002824010) and from the Dr. de Grood-Stichting). 


\section{References}

1. Maartens, L.W., Leusink, L.G., Knottnerus, J.A., Pop, V.J. (2000). Honnonal sulustituturt during menopause: What are we treating? Maturitas; $34(2) ; 1,3=18$.

2. Kaufert, P.A., Gilbert, P., Tate, R. (1992). The Manitoba Project: a reexamination of that link between menopause and depression. Maturitas; $14: 143-55$.

3. Pop, Y.J. Maartens, L.W., Leusink, G.L., Son van, M.J., Weetman, A P. et al (199g), Are auto-immune thyroid dysfunction and depression related? I Cin Endocrinol Matabol 83: 3194-7.

4. Hunter, M., Battersby, R. Whitehead, M. (1986). Relationships between psychological symptoms, somatic complaints and menopausal status. Maturitas; $8: 217-28$.

5. Hunter, M. (1992). The South East England longitudinal Study of the climacteric and postmenopause. Maturitas; 14:117-26.

6. Nicol Smith, L. (1996). Causality, menopause and depression:a critical review of the liter. ature. BMv:313:1229-32

7. Avis, N.E., Mickinlay, S.M. (1991). A longitudinal analysis of women's attitudes towards menopause: results from the Massachusetts Women's Health Study. Maturitas, 13: 65-79.

8. Woods, F.N., Mitchell, S.E. Patterns of depressed mood for midlife women: Observations from the Seattle Midlife Women's Health 5tudy.

9. Smeets Goevaers, C.G., Leusink, G.L., Papapoulos, S.E., Maartens, L.W., Pop, V.J. et al. (1998). The prevalence of low bone mineral density in Dutch perimenopausal women: The Eindhoven Perimenopausal Osteoporosis Study. Osteo int;8:404-9.

10. Cox, J.L., Holden, J.M. Sagovsky, R. (1987). Detection of post-natal depression: devel opment of the 10-item Edinburgh postnatal depression scale. BJ Psych.; 150.782-6.

11. Cox, J.L., Chapman, D. Murray, D., Jones, P. (1996). Validation of the Edinburgh postnatal depression scale (EPDS) in non-childbearing women. J Affect Dis; 39:185-9.

12. Becht, M.C., Erp van, C., Son van, M.1. Heck van G.L., Pop, V.J. (2000). Measuring depression in menopausal women;" Validation of the Edinburgh Depression Scale. J Affect Dis in press.

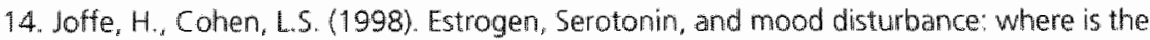
therapeutic bridge? Biol Psychiat; 44(9);798-811.

15. Kaulert, P. (1990). Methodological issues in menopause research. Ann NY Acad Sci, $592: 114-122$ 



\section{Are autoimmune thyroid} dysfunction and depression related?

Published as: Pop, V.J., Maartens, L.W., Leusink, G.L., Weetman, A.P. (1998). Are Auto-immune Thyroid Dysfunction and Depression related? J Cin Endocrinol. Metab.; 83:3194-97. 


\section{A B STRACT}

Objective: To examine the relationship between autoimmune thyroid disease and depression in perimenopausal women.

Design: Thyroid function (TSH, free T4, thyroid peroxidase antibadies TPO-Ab) and depression (using the Edinburgh Depression Scale, EDS) were assessed cross-sectionally together with other determinants of depression. Subjects: 583 randomly selected perimenopausal women (aged 47-54 years) from a community cohort of 6846 women.

Main outcome measures: The occurrence of thyroid dysfunction (abnomal IT4 and/or TSH or elevated levels of TPO-Ab) and the concomitant presence of depression according to the Edinburgh Depression Scale.

Results: Neither biochemical thyroid dysfunction, nor menopausal status were related to depression. Apart from several psycho-social determinants the occurrence of a major life event, a previous episode of depression, finaincial problems), an elevated level of TPO-Ab ( $2100 \mathrm{U} / \mathrm{ml})$ was significantly associated with depression (OR: $3.0,95 \% \mathrm{Cl}: 1.3-6.8$ ).

Conclusions: Women with elevated TPO-Ab levels seem to be especially vulnerable to depression, while the postmenopausal status does not increase the risk of depression.

Keywords: Depression, Thyroid peroxidase antibodies, Menopause, Stressfullife event 


\section{Introduction}

Several clinical signs and symptoms of thyroid dysfunction are similar to depression, and depression may be provoked by underlying overt hypothyroidism [1-3]. Thyroxine replacement increases central 5-hydroxytryptamine activity and reduces depressive symptoms [4]. Depressed inpatients have an increased incidence of (sub)clinical thyroid dysfunction, and women suffering from postpartum depression have a higher prevalence rate of elevated TPO-Ab levels an important marker of autoimmune thyroid disease [5-8]. Moreover, the occurrence of stressful life events (an important determinant of depression) is a risk factor for the development of thyroid dysfunction, particularly Graves' disease $[9,10]$. Most, if not all, of these studies have reported a correlation, while only (and often retrospectively) investigating an association at an univariate level. However, the origin of depression is multifactorial, which means that when looking at the effect of one variable on depression, the influence of other determinants of depression should simultaneously be taken into account [11]. One explanation of the suggested relationship between stress and thyroid disease could be that stress causes depression which, in turn, causes or exacerbates autoimmune thyroid disease.

We have investigated cross-sectionally the relationship between thyroid dysfunction and depression in a community-cohort of perimenopausal women in whom, apart from thyroid function, several determinants related to depression were assessed.

\section{Subjects and methods}

\section{Subjects and sample size}

Between September 1994 and September 1995, all women between 47 and 54 years of age $(n=8503)$ living in the city of Eindhoven in the south-east of the Netherlands were invited for screening of bone mineral density (BMD). Screening occurred at the Diagnostic Centre, Eindhoven and at the St Joseph Hospital, Veldhoven, a suburb of Eindhoven. During the visit for BMD screening, detailed menstrual, gynaecological and general medical histories as well as the use of medication were obtained by paramedical assistants. Blood samples were collected and stored. Moreover, the women were asked to complete several questionnaires at home and to return these within one week of screening. For methodological reasons (use of self-rating scales, racial aspects related to osteoporosis), only Dutch Caucasian women $(n=8098$, of whom $6648(78 \%)$ participated in the study) were included in the analysis. $6116(92 \%)$ of these women returned the questionnaires of whom $4975(81 \%)$ correctly completed the self-rating scales. A one in two sample was randomly selected for the assessment of thyroid status ( $n=$ 
2584). Assuming a prevalence of depression of $25 \%$ and of elewated TPO-Ab titers of $10 \%$ (type l error (alpha) of 0.05 and a power of 0.80 ), a minimum of 548 women would be needed to detect a relative risk of at least 2.0 for TPO-Ab in relation to depression. Therefore, from these 2584 women, a one in four random sample was drawn, resulting in 583 women in whom thyraid status, depression and determinants of depression were assessed.

Apart from the subject"s own informed consent, permission for the study was also obtained from the Medical Ethics Committee at the St loseph Hospital. Veldhoven.

\section{Measurements}

Depression was assessed using the Edinburgh Depression Scale, originally called the Edimburgh Postnatal Depression Scale (EPDS). which is a 10-itern self rating scale, the reliability, sensitivity and specificity of which for detecting depression hawe been proven in postpartum women [12-14]. Recently, the EPDS has been validated for use in nom-childbearing women, and has shown accurate psychometric characteristics resulting in another nomenclature: the Edinburgh Depression Scale (EDS) [15]. A score of 12 or higher on the EDS was defined as depression. Because this study was part of a larger longitudinal study programme of depression in perimenopausal women, after screening a subgroup of 320 women was subsequently visited at home, and in whom, a syndromal diagnosis of depression was made during an interview using the Research Diagnostic Criteria (RDC, Spitzer 1973). Again, the EDS was completed and showed appropriate psychometric characteristics: a predictive value, sensitivity and specificity for detecting (syndromal) depression of $71 \%, 68 \%$ and $92 \%$ respectively.

Thyroid function was assessed by the measurement of $\mathrm{TT} 4$ (reference range: 8-26 pmol/ Abbott), TSH (reference range: $0.4-6 \mathrm{mU} /$, Abbott) and TPO-Ab (Autozyme Tab, Cambridge Life Sciences, Cambridge UK). The coefficients of variation for 144 were $6.8,8.2$ and $6.7 \%$ at concentrations of $6.4,18$, and 30 pmoll, respectively, for TSH of $9.8,4.8,3.9$ and $3.1 \%$ at concentrations of $0.06,0.75,6.8$ and $30 \mathrm{MU} / \mathrm{l}$, respectively, and, finally, for TPO-Ab of $9.6 \%$ at a concentiration of $231 \mathrm{U} / \mathrm{ml}$. Moreover, personal and family history for (previous) thyroid dysfunction was assessed during the screening for BMD. Clinical thyroid dysfunction was defined by the presence of both abnormal TSH and TT4 concentrations, while subclinical thyroid dysfunction was defined by abnormal TSH concentrations with normal fT 4 levels. A TPO-Ab level $\geq 100 \mathrm{U} / \mathrm{ml}$ was defined as positive.

The determinants of depression, assessed in the group of 583 women who completed the EDS and in whom thyroid function was evaluated, included: educational level, previous history of depression in the woman herself or in her first degree relatives, life style habits (current smoking and alcohol intake), marital 
state, working outside the home, financial problems and the occurrence of a major life event [11]. Data analysis refers to this cohort of 583 women.

Statistical analysis

Statistics analysis was performed using the Statistical Products and Service Solutions (SPSS). The relationship between thyroid dysfunction and depression was. investigated by multiple logistic regression analysis, with a high score on the EDS $(\geq 12)$ as the dependent variable.

\section{Results}

The characteristics of the women in the various cohorts are shown in Table 1 . The demographic features, gynaecological status, lifestyle habits and thyroid parameters were equally distributed in the total cohort $(n=4975)$, in the cohort of women in whom thyroid function was assessed $(n=2584$ ), and in the cohort of women ( $n$ $=583$ ) in whom the questions being studied were analysed.

According to the EDS $(\geq 12)$ the prevallence of depression was equally distributed in the three cohorts ( $24 \%, 21 \%$, and $23 \%$ respectively, Table 1$)$. Subset analysis in pre-, peri-, and post-menopausal women did not reveal any difference in prevalence rates of TPO-Ab and depression.

of the 583 women in whom both thyroid function and determinants of depression were assessed, $3(0.5 \%)$ had clinical hyperthyroidism, $2(0.4 \%)$ dinical hypothyroidism, $15(2.5 \%)$ subclinical hyperthyroidism, $23(4 \%)$ subclinical hypothyroidism, and $58(10 \%)$ high TPO-Ab levels $\geq 100 \mathrm{U} / \mathrm{ml})$. A further 6 women (1\%) were euthyroid due to thyroid hormone therapy, and $13(2.2 \%)$ were euthyroid due to previous treatment for hyperthyroidism. Several independent thyroid related and psycho-social wariables were entered into a multiple logistic regression analysis, using a high score on the EDS ( $\geq 12)$ as the dependent variable (Table 2). The occurrence of financial problems, caring for parents, $\vec{a}$ previous episode of depression in the woman's life, the occurrence of a major life event, and an elevated concentration of TPO-Ab ( $\geq 100 \mathrm{U} / \mathrm{m}$ l) were all significantly and independently related to depression. Thyroid dysfunction (either clinical or subdinical) was not related to depression and neither was menopausal status. 


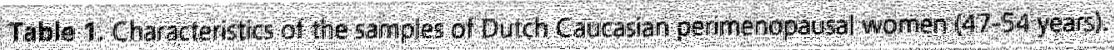

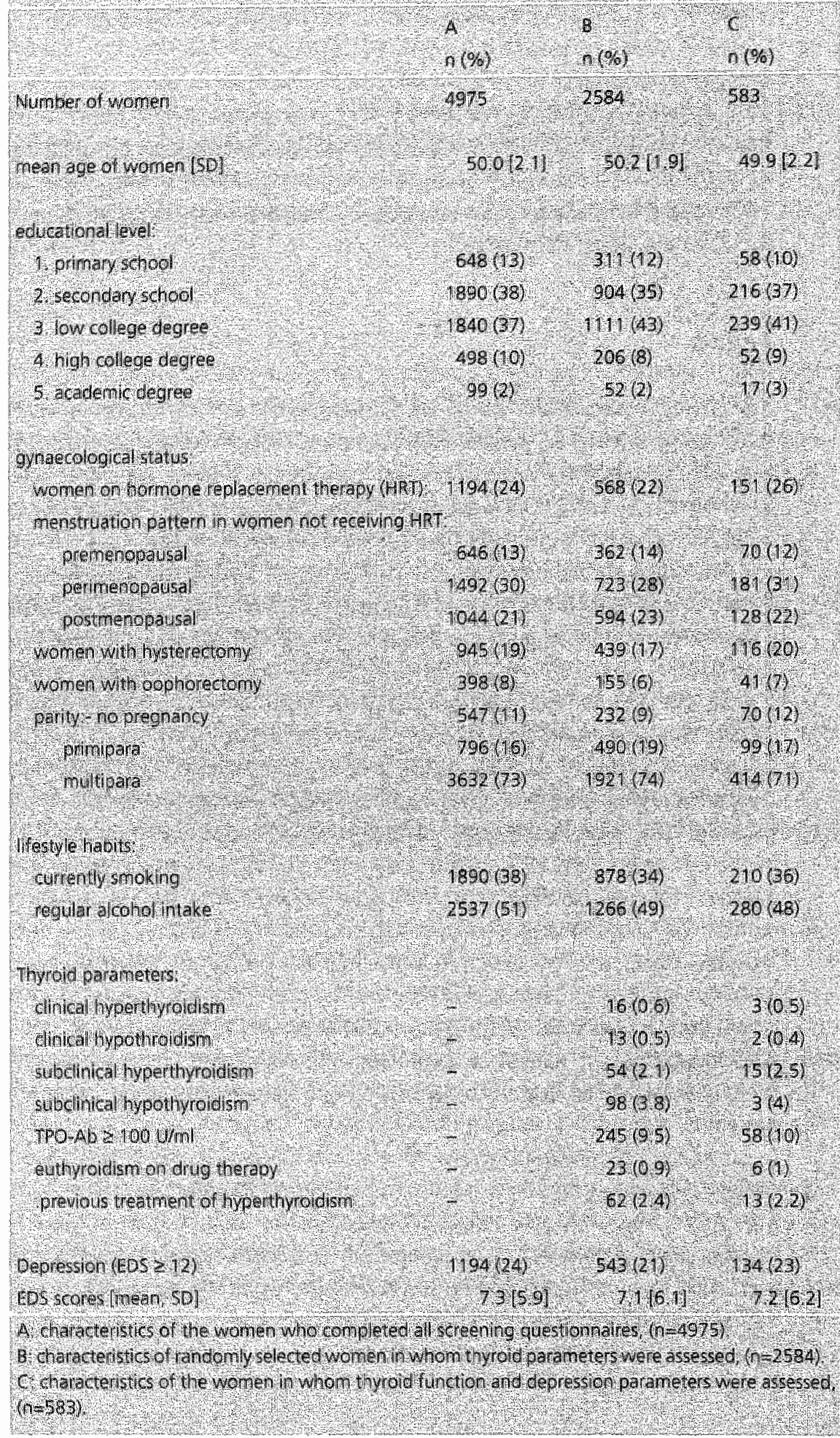




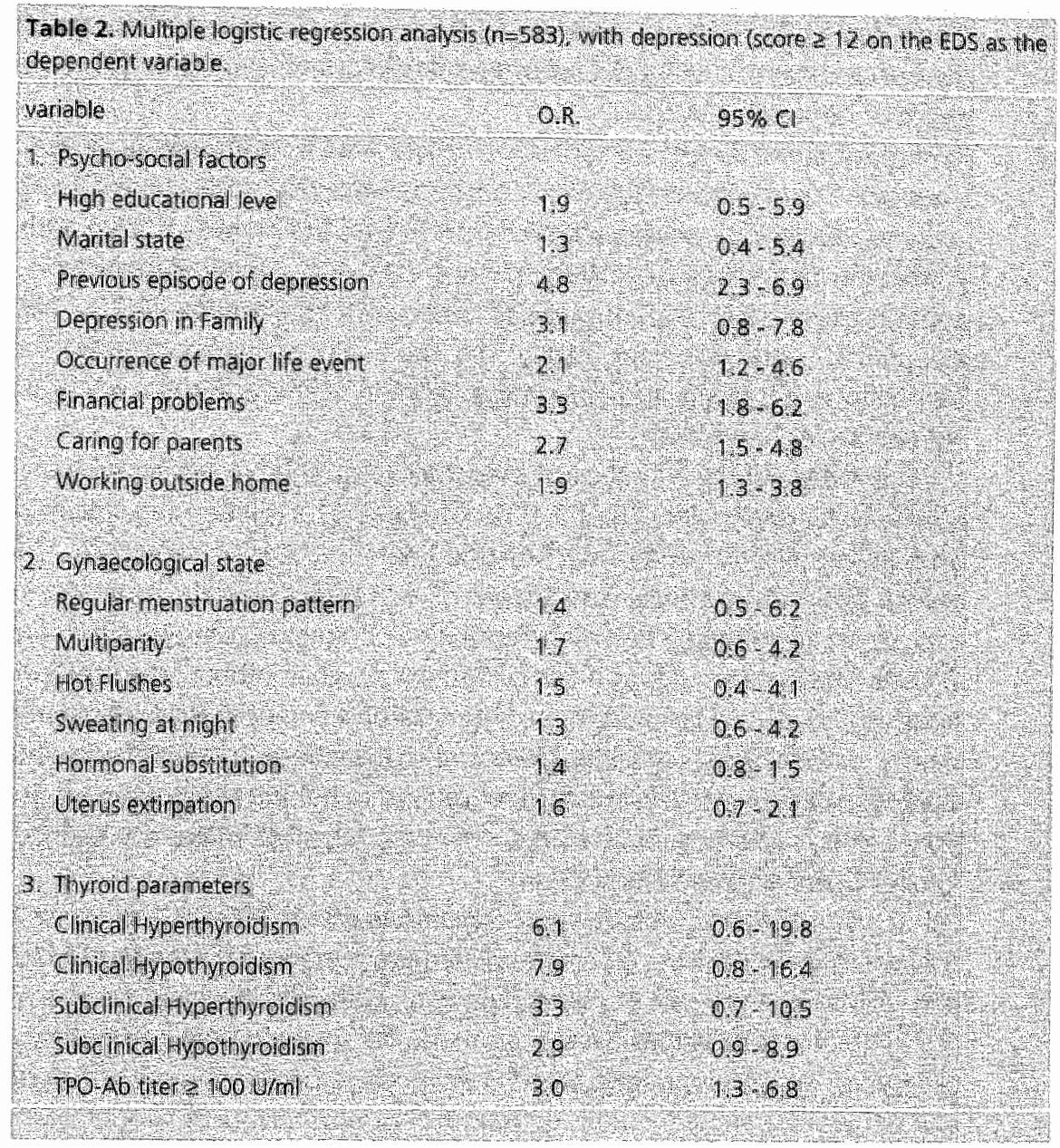

\section{Discussion}

The characteristics of the various study groups (Table 1) are similar, indicating that the group of women studied is representative of the total community-based cohort of perimenopausal women. Most studies investigating the relationship between menopausal state and depression failed to use a standardized assessment of depression, or to show evidence that the study group was representative of the general population of perimenopausal women [16]. in the present study, neither the presence of perimenopausal complaints nor the menopausal status of the women were related to depression, which suggests that changes in hormone concentrations of estrogens and progesterone (as reflected by an irregular menstruation pattern) do not make a woman more susceptible to depressive 
symptoms [16]. Postnatal women also falled to show a relationship between abrupt changes in estrogens and progestagens after child-bearing and the occurrence of depression [17].

Recent epidemiological studies on the occurrence of depression in the general population revealed a one year (period) prevalence of $7-11 \%[18,19]$. In postnatal women, a (period) prevalence of 10-15\% has been shown [17], and several studies on perimenopausall women have indicated a (period) prevalence in the community of $16-21 \%$, and even of $36 \%$ at permenopausal dinic $[18,19,20]$. Apparently, although our study did not show any correlation between perimenopausal status and depression, women of this age seem to be especially vulnerable for depression.

This is the first study to show that women with a high concentration of TPO-AD are at risk for depression (OR:3.0,95\% (l:1.3-6.8), a relationship which still exists after adjustment for other (psychosocial) determinants of depression. There are several postpartum studies and studies of a general psychiatric population which also report a correlation between depression or a rapid cycling mood disorder and TPO-Ab status (although at an univariate level) while others falled to find a relam thonship $[7,8,21,22]$. Because there is general agreement that the origin of depression is multifactorial, possible biological explanations of depression should be studied together with the influence of other psychological aspects such as educational level, socio-economic status, the occurrence of major life events, and a family history of depression [11].

Up to $10 \%$ of fertile women have elevated levels of TPO-Ab and, once an individual is TPO-Ab positive, he or she will tend to remain so for the rest of his/her life and will be at high risk of developing clinical thyroid dysfunction in the future $[3,23]$. Recommendations have been made for screening women during or after pregnancy in order to detect the TPO-Ab positive cases, who are at risk of devel oping thyroid dysfunction during pregnancy or postpartum or later in life [24]. This study would add another argument for the screening of TPO-Ab during pregnancy, because of the significant association with later depression.

The cross-sectional design of our study does not resolve the problem of whether auto-immune thyroid dysfunction (as reflected by the presence of TPO-A.b) proceeds depression or, vice versa. The only way to address this would be to undertake a longitudinal study, during which subjects would be followed for a long period of time. Pregnant women would be an appropriate study population: $10 \%$ have elevated levels of TPO-Ab (and remain positive for the rest of their lives) and the prevalence of depression is high, with a lifelong cumulative incidence of depression of at least $20 \%[17,18,19]$.

We conclude that depression, although not related to menopausal status, has a high prewalence in perimenopausal women in the community. The psychowsacial determinants of depression are no different from those found for depression in 
general. The presence of one biological stable marker (TPO-Ab) is associated with, and may make women more vulnerable for, depression.

Acknowledgments. The authors thank the members of the Eindhoven Study management team, Dr. J. Keyzer. Prof. dr. H. Pols and Prof. dr. 5. Papapoulos, for their participation in the study and their critical review of the manuscript.

This study was kindly supported by a grant from the Praeventiefonds (project No. 002824010), the Dr. De Grood foundation and Merck Pharmaceuticals, BV The Netherlands. 


\section{References}

1. Lazarus, J.H.(1997). Hyperthyroidism Lancet,349:339-43.

2. Lindsay, R.S., Tof, A.D.(1997). Hypothyroidism. Lancet, 349.413-17.

3. Weetman, A.P.(1997). Hypothyroidism: screening and subclinical disease. BMj; 314 : $1175-1178$

4. Cleare, A.1. McGregor, A, Chambers, S.M., Dawing, S., O'Keane, V. (1996). Thyroxine replacement increases central -hydroxytryptamine activity and reduces depressive symp. toms in hypothyroidisim. Neuroendocrinology, 64(1):65-69.

5. Esposito, 5. Prange, A.1. Golden, R.N. (1997). The thyroid axis and mood disorders: overview and future prospectives. Psychopharmacol Bul/33(2):205-217.

6. Pop, V.J., de Rooy, H.A. Vader. H.L. et ail. (1991). Postpartum thyroid dysfunction and depression in an unselected population. N Engl / Med,324:1815-1816.

7. Harris, B., Othman, 5., Davies, J.A. et al. (1992). Association between postpartum thyroid dysfunction and thyroid antibodies and depression. BMJ:305:152-6.

8. Pop. W.j., de Rooy, H.A., Vader, H.L., Heide van der, D., wan Son, M.J., Komproe, 1.(1993). Microsomal antibodies during gestation in relation to postpartum thyroid dysfunction and depression. Acta Endocrinol Scand; 129:26-30.

9. Wirisa, B. Adami, H.O., Bergstrom, R. et al.(1991). Stressful life events and Grawes' disease Lancet;338:1475-1479.

10. Kung. A.W.(1995). Life events, daily stresses and coping in patients with Grawes disease. Clinic Endocrinol:42:303-308.

11. Gelder, M., Gath, D.(1994). Affective disorders. In: Gelder M, Gath D, Mayou R eds. Oxford Textbook of Pychiatry: 133-162.

12. Cox, J.L., Holden, J.M., Sagowsky, R.(1987). Detection of depression: Development of the 10-item Edinburgh Postnatal Depression Scale. Br J Psychiat; 150:782-786.

13. Harris, B., Huckle, P. Thomas, R., John, S. Fung. H.(1989). The use of rating scales to identily postnatal depression. Br J Psychiat; 154:813-817.

14. Pop, W.1., Komproe, I., Son van, M.J. (1992). Characteristics of the Edinburgh Postnatal Depression Scale in the Netherlands. A Affect Disord; 26:105-110.

15. Cox, J.L., Chapman, G., Murray, D., Jones, P. (1996). Validation of the Edinburgh postnatal depression scale (EPDS) in non-postnatal women. Affect Disord;39:185-189.

16. Nicol-5mith, h. (1996). Causality, menopause, and depression: a critical review of the literature. Br Med j; 313:1229-1232.

17. OHara, M.W. (1995). Postpartum Depression. Causes and Consequences. Springer Verlag, New York

18. Kessier, R.C. McGonagle, K.A., Zhao, S. ell al. (1994). Litetime and 12-month prevalence of DSM-III-R psychiatric disorders in the United States. Results from the National Comorbidity 5tudy. Arch Gen Psychiat, 51:8-19.

19. Bill, R.V., Zessen van, G, Ravelli, A (1997). Psychiatric morbidity among adults in the Netherlands: the NEMESIS study II. Prevalence of psychiatric disorders. Ned Tigdschr Geneesk, 141(50):2453-2460.

20. Hay, A.G. Bancroft, 1. Johnstone, E.C. (1994). Affective symptoms in women attending a menopause clinic. Br J Psychiat; 164(4):513-516.

21. Oomen, H.A., schipperilin, A.M., Drexhage, H.A. (1996). The prevalence of affective disorder and in particular rapid cycling of bipolar disorder in patients with abnormal thyrod function tests. Clin Endocrinal ; 45:215-223. 
22. Haggerty, J.J. Ir, Silva, 5.G., Marquardt, M. et al. (1997). Prevalence of antithyroid antibodies in mood disorders. Depress-Anxieb; $5(2): 91.96$.

23. Vanderpump, M.P., Tumbridge, W.M. French, IM. et al. (1995). The incidence of thyroid disorders in the community: a twentywear followwup of the Wickham Survey. Clin Endacrinol, 43:55-68.

24. Glinoer, D. (1997). The regulation of thyroid function in pregnancy: pathways of endocrine adaptation from physiology to pathology. Endo Rev; 18(3)-404-425. 
General discussion 


\section{Introduction}

The menopause is a phase of life with a diversity of angles of approach regarding the experience of a changing awareness of health or illness. During the course of the past 40 years, these changes have been investigated in a variety of ways. In our study, we carried out a population-based investigation into five different health problens with a large burden of illness during the climacteric, which eventually also showed a certain correlation. We carried out successive investigations into the areas of osteoporosis, menopausal complaints, medicine use, depression, and thyroid dysfunction. The results of the study will be evaluated below.

\section{Main results}

\section{Osteoporosis}

In the Eindhoven Perimenopausal Osteoporosis Study (EPOS), the perimenopausal female population of Eindhoven was screened for bone mineral density by means of DEXA measurement. The prevalence of osteoporosis and osteopenia was 4.1 and $27.3 \%$, respectively. The results were obtained in an unselected population, and cannot be directly compared with those of other studies, due to differences in study design and subject selection criteria. However, the outcomes are comparable to those of studies on women of the same age in the UK [1], France [2], and Finland [3]. We found a connection between reduction of BMD and age, despite the narrow age margin. However, this can be explained by a larger percentage of menopausal women in the higher age groups rather than simply by a chronological age effect. Menopause itself appeared to be a very strong risk factor for low $B M D$, which was also related to years since menopause. In the perimenopausal group, a separate analysis according to age shows a prevalence of osteoporosis of $1.4 \%$ at 48 years of age, and of $1.3 \%$ at 53 years of age, while the prevalence of osteopenia is 13.4 and $14.1 \%$, respectively. A high body mass index (OR 0.90 ) and estrogen use (OR 0.81) both have a protective effect on the skeleton, as has often been reported [4]. Of the other commonly assessed risk factors, smoking has a negative effect on BMD (OR 1.25), while alcohol consumption has a protective one (OR 0.71). Our findings also suggest, although not definitely, that an increased risk of osteoporosis may be considered a potential complication of hysterectomy in young women [5-7].

\section{Climacteric complaints}

We compared the differences in menopausal complaints between the three menopausal phases, namely, pre-, peri- and post-menopause. When comparing 
post-and premenopause, we found that vaginal dryness, pain during intercourse, flushing, and insomnia occurred more often, while vaginal discharge and depressed mood occurred less often, in the postmenopause. When comparing peri-and premenopause, we found that only flushing occurred more often in the perimenopause. When comparing post- and permenopause, vaginal dryness, pain during intercourse, flushing, and insomnia were found to occur more often in the postmenopause, while vaginal discharge and vaginal itching occurred less often. Flushing is the only symptom that was significantly different when we compared all three menopausal phases together. However, the chance of flushing is much higher between pre- and perimenopause (OR 5.9) than it is between periand postmenopause (OR 2.0). Although it is often suggested that insomnia is related to nightly wasomotor problems $[8-17]$, we found insomnia to be independently significantly different between pre- and postmenopause (OR 0.5), whereas sweating at night was never significantly different. Waking at night was the most frequent complaint in pre- peri-, and postmenopause (present in 62,72 and $78 \%$, respectively).

\section{Hormone replacement therapy (HRT)}

In this study, we investigated to what extent perimenopausal complaints, subdivided into three subscales (cognitive/vegetative, vasomotor, and urogenital), can be explained by depressive symptomatology. We found that the score on the Edinburgh Depression Scale (EDS) was highly correlated with the cognitive-vegetative subscale (correlation coefficient $=0.72$ ). Analysis of variance (ANOVA) in women using HRT showed the highest (mean) scores on all subscales, and on the EDS Furthermore, in a multiple linear regression analysis, EDS scores contributed the most to the explained variance on the subscales. Only postmenopausal status proved to be a more important determinant of the variance of the scores on the vasomotor subscale.

\section{Benzodiazepines (BZD)}

The prevalence of $\mathrm{BZD}$ use in our population was $7.6 \%$. When comparing the group of $B Z D$ users with that of non-users, we found a number of remarkable differences: BZD users have a lower level of education, have more often undergone gynaecological surgery in the form of hysterectomy, are more often divorced $(25 \%)$ are more often dally users of alcohol $(31 \%)$, are more often smokers $(38 \%)$, and make more use of antidepressants (13\%), pankillers $(38 \%)$, gastric remedies $(8 \%)$, and oestrogens (37\%). In $31.1 \%$ of cases, BZD users presented with a more than average number of perimenopausal complaints, compared to only $11 \%$ of the non-users. Of all the BZD users, no less than $51 \%$ had EDS scores $>12$, compared to 'only' $19 \%$ of the non-users. In a multiple logistic regression 
analysis, oestrogen use (OR 1.5), smoking (OR 1.7) and EDS score (OR 4.6) were found to be independent determinants for a higher risk of benzodiazepine use.

Menopausal transition and increased depressive symptomatology

In a cohort of 2103 perimenopausal women, cross-sectional data on two consecutive points in time (T1 and T2) showed that the EDS score was lowest in the premenopause and was higher in the peri and postmenopause, respectively. In the longitudinal design, there was an increase in the EDS score in all transition groups except in those women who were already postmenopausal at $\pi 1$. The number of women with an EDS score $>11$, as well as the mean EDS scores in the total group, increased during follow-up. A previous episade of depression tOR 2.0), unemployment (OR 3.1), and the inability to work outside the home (OR 1.7), as well as the occurrence of a major life event, appeared to be independent factors that caused a high increase $(>5.7)$ on the EDS. In contrast to earlier findings in the literature [18], we found that the transition from peri- to postmenopause was another independent factor leading to a strong increase $(>5.7)$ on the EDS IOR 1.8).

\section{Thyroid dysfunction}

In a cohort of 583 womem, both thyroid function and determinants of depression were assessed. Of these women, $0.5 \%$ had cinical hyperthyroidism, $0.4 \%$ clinical hypothyroidism, $2.5 \%$ subclinical hyperthyroidism, $4 \%$ subclinical hypothyroidism, and 10\% high TPO-Ab titers ( $>100 \mathrm{U} / \mathrm{m}$ ll). Multiple logistic regression analysis was carried out with a high EDS score as the dependent variable. Financial problems, caring for parents, a previous episode of depression, the occurrence of a major life event, and an elevated concentration of $\mathrm{TPO}-\mathrm{Ab}(>100 \mathrm{U} / \mathrm{ml})$, were all significantly and independently related to depression. Thyroid dysfunction was not related to depression.

\section{Methodological aspects}

\section{Strengths and limitations}

In this section methodological strengths and limitations in general and in the chapters respectively will be discussed.

General Strength - In chapter 2 - 7 all data refer to a large unbiased population based sample. 
CHAPTER 2

Limitations

Strengths

CHAPTER 3

Limitations

Strengths

CHAPTER 4 Limitations

Strengths

CHAPTER 5

Limitations

Strengths
- Screening of bone mineral density (BMD) was assessed on the lumbar spine. BMD of the femoral neck was not assessed, being the most relevant site of the body for the prediction of future (hip)fractures and the possible results of intervention.

- We studied perimenopausal women in a narrow age range between 47 and 54 years of age.

- Because of the number of women studied $(n=5896)$ there is enough epidemiological power.

- Excluding women because of estrogen-use, premenopausal phase, and only assessing BMD in women going from perito post menopause, leaves us with only $18.3 \%$ of all women of the total population. Screening of these women is likely to reveal low BMD in $55 \%$

- Cross-sectional designs can identify associations and can only suggest changes over time. No correlation between climacteric transition and appearance / disappearance of complaints can be made.

- Discrimination of complaints in relation to menopausal status can be made not biased by estrogen use and /or gynaecological status) In our survey we had a high response rate of fully completed questionnaires.

- No assessment was made concerning the reason and duration of hormonal substitution on the moment of completing the questionnaire.

- Uniform assessment of menopausal complaints [21] and depressive symptoms [38] by standardized scales.

- Factor analysis of menopausal complaints on a self-rating questionnaire in non-estrogen users discriminated 3 sub-scales of which the face validity corresponds with the anamnesis of the menstrual pattern.

- The detection that in an unbiased sample depressive symptoms seem to be a more prominent reason to use HRT rather than non-specific menopausal complaints.

- No assessment was made concerning the reason and duration of taking benzodiazepines.

- insight in use of benzodiazepines in an open population as one of only a few studies. Confirmation that use of benzo- 
CHAPTER 6

Limitations

Sirengths

CHAPTER 7

Limitations

Strengths diazepins actually reflects undiagnosed depression which in turn is also reflected by high utilisation pattern of symptomatic drugs an poor life style habits (in an open population).

- The mean duration of the perimenopause was not assessed. Therefore we cannot comment on the possible prediction of symptoms of depression by duration of perimenopause.

- We assessed the intra-individual relationship between climacteric transition (pre/peri, peri/post and pre/post) and change of depressive symptoms.

- Despite a short period of longitudinal follow-up this survey still covered $50 \%$ of the women going through one menopausal status to another. Because of this short interval the range of years between the two assessments is very unlikely to influence the observed change of depression (by age and demographic determinants).

- The cross-sectional design of our study does not resolve the problem of whether autoimmune thyroid dysfunction (as reflected by the presence of TPO-Ab) precedes depression or vice versa.

- The sample-size is probably too small to correlate thyroid dysfunction with depressive symptoms

- We studied a large sample of perimenopuasal women with blinded assessment.

- Although we took multivariate aspects in consideration (including other known important determinants of depres. sion) the presence of TPO-Ab as a independent determinant was still valid.

\section{What did we learn}

The EPOS is a cross-sectional population study. Only a few other large-scale studies meet the same criteria $[15,19-20]$. The fact that, in the EPOS study, we moreover confined ourselwes to a narrow age margin, makes this study rather unique. In the open population. we found a $4.1 \%$ prevalence of osteoporosis around the menopause, and a $27.3 \%$ prevalence of osteopenia. Menopausal status, bilateral ovariectomy, and smoking are known determinants of reduced BMD, which we were able to confirm. Hormone use and alcohol consumption could have a protective effect.

By studying the relationship between menopausal complaints and the different phases of transition (pre-peri, pre-post and peri-post), we can rate these 
complaints at their true value, in relation to their place in time. General practitioners are regularly confronted with the question: "Has the transition started already?" A year after menstruation has ended, it is easy enough to determine retrospectively that menopause had already set in. Defining complaints as being perimenopausal would seem to be less easy when waginal blood loss is still occurring. As has already been shown in previous studies [19.21], we also found that hot flushes are most likely to occur during the transition from pre- to perimenopause, whereas they are only likely to occur twice as often in the early postmenopause compared to the perimenopause. Flushing was also found to be the only complaint that differed significantly between pre- and perimenopause. Typical urogenital complaints showed no discrimination between pre- and perimenopause, but there was a clear difference between peri- and postmenopause.

We found it remarkable that waking up during the night is the most presented complaint during all phases, but does not occur significantly more often during one menopausal phase compared to another. However, insomnia does sinow a significant difference, but only between post- and premenopause. These data can be a help to general practitioners in the diagnosis of a large variety of 'dimacteric' complaints in relation to a particular phase of the menopause.

Because this duster of often rather vague complaints is frequently presented, to both general practitioners and specialists, by women in the age category between 47 and 54 years, such complaints will easily be associated with the menopause, and therefore, with oestrogen deficiency. Consequently, hormone replacement therapy will be considered a solution. Only for vasomotor complaints did we find the menopausal status to be the most significant independent determinant in women not using HRT. For all the other menopausal complaints, which, by means of factor analysis, were classified into three subscales, the depression score (EDS) was found to be the most important determinant. No direct correlation between somatic and emotional complaints and reduced oestrogen production was found anywhere in the literature $[22-23]$. Our research suggests that, when confronted with menopausal complaints, several of which are regarded as being 'typically menopausal", physicians should be alert to the presence of an underlying depression. This is even more noticeably corroborated by the fact that HRT users scored highest on the EDS scale. From this, it could be concluded that, in particular women presenting with cognitive/vegetative complaints around the menopause, are more likely to be suffering from (underlying) depression than that these complaints could be explained by hormone deficiency and/or could be treated with HRT. We would recommend a more accurate diagnosis of depression during the climacteric.

Just as, at the time of the menopause. HRT is prescribed more frequendly, "vague complaints are also regularly treated with $B Z D$. We found that one-third of all BZD users presented with more than average menopausal complaints, 
compared to one of ten non-users. Both with regard to life style and from a sociodenographic point of view. BZD users clearly showed inferior characteristics. We also found that (apart from the earlier shown positive correlation with HRT) the EDS score is a significant independent determinant for BZD use. On the basis of this characterization of BZD users during the climacteric, we would emphasize once again that imely diagnasis and adequate treatment of depression can reduce the use of $\mathrm{BZD}$ and other medications, can improve life style, and relieve the burden of depression.

The longitudinal follow-up of the EPOS cohort enabled us to form an opinion on the influence of the menopause on EDS scores. Despite the fact that neither a large-scale meta-analysis [18] nor our own cross-sectional data [24-25] showed a relationship between menopause and depression, in our cohort we found an independent correlation between the transition from peri- to postmenopause, and a high increase of depressive symptoms. The definitive termination of oestrogen production by the ovaries, in combination with the discontinuation of menstrual vaginal blood loss, could explain this. It has been shown that oestrogen is capable of modulating seretonergic function in the central nervous system [26], and several models have been proposed to explain oestrogen-seretonine interaction. suggesting an increased vulnerability to affective disorders in women with hormonal changes during the female life cycle [27-28]. History repeats itself, because, in the 1970 s and 1980s, "the menopausal syndrome" was the explanation for the idea that depression was related to oestrogen deficiency, and that, therefore, HRT could possibly be effective against depression [29-33].

With reference to the existing literature [34-36], we also studied the relationship between thyroid dysfunction and depression. It has already been shown that autoimmune antibodies to thyroid tissue are a risk factor for higher depression scores after childbirth. In our EPOS cohort, we also found that the presence of an important marker of autoimmune thyroid disease is associated with, and makes many women more vulnerable to, depression. Because there is general agreement that the origin of depression is multifactorial, we suggest that autoimmune thyroid disease, as a biological explanation of depression, should be studied together with the influence of other psychological aspects, such as educational level, socio-economic status, occurrence of major life events, and prior depression or a family history of depression [37].

\section{Conclusions and Recommendations}

Over the past few years, this study has provided us with a clear picture of the health profile of the study group of perimenopausal women between the ages of

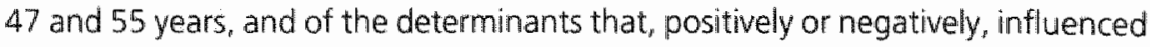
their health and their perception of health. We studied clinically measurable 
parameters such as bone density and thyroid function, as well as subjective anamnestic data with regard to menopausal complaints and depression, and other anamnestic data with regard to objective issues such as the use of medicine and gynaecological case history.

This resulted in the following picture: in the perimenopause, a small number of women already have osteoporosis $(4.1 \%)$, and a larger number have osteopenia (27.3\%). Only when we can prove prospectively that safe and effective treatment can be provided to prevent future fractures, would BMD screening in risk groups seem to be realistic.

The most frequently presented menopausal complaint is waking up during the night. However, this complaint does not discriminate between pre-, peri- and postmenopause. Hot flushes is the only menopausal complaint to discriminate between pre- and perimenopause, while uragenital complaints only start to play a role when vaginal blood loss definitively comes to an end. Climacteric women present with a rather large range of varied complaints during which, with the exception of vasomotor complaints, the possibility of underlying depression should be taken into consideration. In the case of depression, the use of either HRT or BZD to combat these complaints has little effect. Worse still, women with higher depression scores who use HRT are more liable to menopausal complaints than women who do not use HRT and do not have raised depression scores. The health condition of menopausal women using BZD is disturbing, with regard to the use of multi-medication as well as to the existence of depressive symptomatology and the consumption of alcohol and nicotine. The diagnosis and treatment of depression could mean an improvement, with regard to both their life style and their psychosocial functioning. Contrary to the world literature, the longitudinal part of our study did show that the transition from peri- to postmenopause was a risk factor for depression. Further population-based studies are necessary to confirm this, and placebo-controlled clinical trials will be needed in the future in order to verify any antidepressant effects of, for example. HRT, in this category of women.

Over $10 \%$ of fertile women show increased titres of autoimmune antibodies to thyroid tissue (TPO Ab). This will remain unchanged for the rest of their lives, which makes them significantly more at risk for developing thyroid dystunction. Both increased TPO-Ab titres and thyroid dysfunction are independent risk factors for depressive symptomatology. The presence of a stable biological marker in the form of TPO-Ab is associated with, and may make many women more vulnerable to, depression. 


\section{References}

1. Compston, J.E., Cooper, C., Kanis, J.A. (1995). Bone densitometry in dinical practice. $B M / 310: 1507-10$.

2. Pouilles, J.M., Tremollers, F., Ribot, C. (1993). Spine and femur desitometry at the menopause: are both sites necessary in the assessment of the risk of osteoporosis? Calcif Tissue int:52:344-7.

3. Kroger, H. Tuppurainen, M, Honkanen, R, Ahava, E., Saarikoski, 5. (1994). Bone mineral density and risk factors for osteoporosis: a population-based study of 1600 perimenopausal women. Cakif Tissue int; 55:1-7.

4. Michaëlsson, K. Bergström, Malmin, H., Holmberg, L., Wolk, A., Ljunghall, S. (1996). Screening for osteopenia and osteoporosis: selection by body composition. Osteoporas int:6:120-6.

5. McPherson, K., Strong, B., Epstein, A., Jones, L. (1981). Regional variations in the use of common surgical procedures: within and between England and Wales, Canada and the United States of America. Soc SCi Med; 15A:273-88.

6. Coulter, A., McFherson, K., Vessey, M. (1988). Do British women undergo too many or too few hysterectomies? Soc Sci Med:27:987-94.

7. Lilford, R.J. (1997). Hysterectomy: will it pay the bills in 2007? Treatment of choice for cancer, but a choice of treatment for menorrhagia. BMi; 13:160-1.

8. Barlow, D.H. Brockie, J.A. Rees, C.M.P. (1991). Study of practice consultations and menopausal problems. BM/302:274-6.

9. Hagstad et al. (1986). The epidemiology of climacteric symptoms. Acta Obstet Gynecol Scand Suppl. $134.59-65$.

10. Hunter, M., Battersby, R, Whitehead, M. (4986). Relationships between psychological symptoms, somatic complaints and menopausal status. Maturitas;8:217-228.

11. Kaufert, P., Gilbert, T., Hassard, T. (1988). Researching symptoms of menopause : an excercise in methodology. Maturitas; 10:117-131.

12. Aloysio, A., Fabiani, A., Maulini, M., Bottiglioni, F. (1989). Analysis of the climacteric syndrome; Maúuritas; 11:43-53.

13. Avis et al, (1991). A longitudinal analysis of women's attitudes toward the menopause: result's from the Massachusetts Women's Health Study. Maturitas; 13:65-79.

14. Hunter, M. (1992). The South-Eastit England longitudinal study of the climacteric and postmenopause. Maturitas: 14:117-126.

15. Holte, A. Mikkelsen, A. (1991). The menopausal syndrome, Maturitas; 13:193-203.

16. Hunter, M. (1990). Somatic experience of the menopause: A prospective study Psychosom Med, 52:357-367.

17. Matthews et al. (1990). Influences of natural menopause on psychological characteristics and symptoms of middle aged healthy women. I Consult Clin Psychoi:58:345-51.

18. Nicol Smith, L. (1996). Causality, menopause and depression:a critical review of the literature. $B M 1313: 1229-32$

19. Mckinlay, S.M., Mckinlay, J.B. (1986). Health status and heaith care utilisation by menopausal women. In: Notelowitz $M$, Van Keep $P$, eds. The Climacteric in Perspective, pp59-75. MTP Press Ltd Lancaster.

20. Kaufert, P.A. (1984). Women and their health in the middle year: a Minnitoba project. Soc Sci Med; 18:279-81. 
21. Oldenhave, A. Jaszman, L...B. Haspels, A.A. Everaerd Wth, A.M. (1993). lmpact of climacteric on well being. Am I Obstet Gynecol, 168:772-780.

22. Pearlstein, T.B. (1995). Hormones and depression: What are the facts about premenstrual syndrome, menopause and hormone replacement therapy? Am 1 Obst Gyn:173: 646-653.

23. Jane Pearce, Keith Hawton, Fiona Blake. (1995). Psychological and sexual symptoms associated with the menopause and the effects of Hormone Replacement Therapy. $B$ J Psych:167:163-173.

24. Pop, V.J., Maartens, L.W., Leusink, G.L., Son van, M.J, Weetman, A.P. et al. (1998), Are auto-inmune thyroid dystunction and depression related? \& Cin Endocrinol Metabol:83:3194-7.

25. Becht, M.C., Erp van, C., Son van, M.J., Heck van, G.L., Pop, V.J. (2000). Measuring depression in mencpausal women; Validation of the Edinburgh Depression Scale. 1 Affect Dis in press.

26. Joffe, H. Cohen, L.S. (1998), Estrogen, Serotonin, and mood disturbance: where is the therapeutic bridge? Biol Psychiat:44(9):798-811.

27. Rubinow, D.R., Schmidt, P.」, Roca, C.A. (1998), Estrogen-Serotonin interactions: implcations for affective regulation. Biol Psychiatry:44(9):839-50.

28. NAMS/Solvay Resident Essay Award. (1999). Relationship between estrogen, serotonin and depression. Menopause; 6(1):71-8.

29. Palinkas, L.A., Barrett-Connor, E. (1992). Estrogen use and depressive Symptoms in Fostmenopausal women. Obstet Gynecol;80:30-6.

30. Avis, N., Brambilla, D. .McKinlay, S., Vass, K. (1994). A longitudinal analysis of the association between menopause and depression. Results from the Massachusetts Women's Health Study. Ann Epidemiol:4:214-220.

31. Kaufert, P., Gilbert, P., Tate, R. (1992). The Mannitoba Project : a re-examination of the link between menopause and depression. Maturitas; 14:143-55

32. Lopez Jaramillo, P., Teran. E., Molina, G., Rivera, J, Lozano, A. (1996). Oestrogens and Depression. Lancet:348(9020):135-6.

33. Hunter, M., Lih Mei Liao, K. (1994). Intentions to use hormone replacement therapy in a community sample of 45 year old women. Maturitas; 20:13-23.

34. Omen, H.A., Schipperijn, A.M., Drexhage. H.A. (1996). The prevalence of atfective disorder, and in particular rapid cycling of bipolar cydic disorder in patients with abnormal thyroid function tests. Gin Endocinol $(0 \times 1), 45: 215-223$.

35. Vanderpump, M.P., Tunbridge, W.M. French, J.M., et al. (1995). The incidence of thyroid disorders in the community: a twenty year follow-up of the Wickham Survey. Clin Endocrinol $(0 \times 1) \cdot 43: 55-68$.

36. Pop, V.J., de Rooy, H.A., Vader, H.L. et al. (1991), Postpartum thyraid dysfunction and depression in an unselected population. N Eng / Med;324:1815-816.

37. Gelder, M., Gath, D. (1994). Affective disorders. In: Gelder M. Gath D, Mayou R, eds. axford textbook of psychatry. Oxford: Oxford Medical Publications 133-162. 


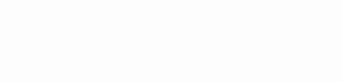

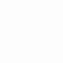

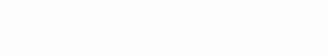
(n) (n) $+2$ . 


\section{Summary}

Chapter 1 gives an introduction as to which problems general practitioners are confronted with, concerning a rather extensive range of variable and often vague complaints, presented by women going through the early stages of menopause. Although the existence of a "menopausal syndrome" is no longer accepted, in popular as well as in medical literature, menopausal women are still frequently considered as suffering from a considerable array of problems. The context of the Eindhoven Perimenopausal Osteoporosis Study (EPOS) is explained. Several (extensive) questionnaires, DEXA, and bloodsamples provided us with detailed information. By means of these data we attempted to answer the following questions:

1. What is the prevalence of osteoporosis and osteopenia in women around the menopause, and what are the most important determinants of low bone mineral density (BMD).

2. Are there differences in the occurrence of (the intensity of) menopausal complaints known from the literature when comparing the three climacteric phases to be distinguished: pre-, peri-, and post-menopausal phase.

3. Can an association be found between the diverse and often vague complaints noted around the menopause and the declining levels of estrogen, and what is the relation with estrogen use. Is there an overlap between menopausal complaints and depressive symptomatology?

4. Are benzodiazepines used for specific complaints during the climacteric, what are the characteristics of these users, and what are the determinants influencing the use of benzodiazepines?

5. Is there an association between depressive symptomatology and the transition from pre- to peri- and post-menopause, and what is the influence of other determinants?

6. Depression may be provoked by underlying overt hypothyroidism [44-46]. The occurrence of stressful life events (an important determinant of depression) is a risk factor for the development of thyroid dysfunction [42-43]. Is there an association between depression and autoimmune thyroid dysfunction?

In Chapter 2 the results of a cross-sectional study are presented. The aim of this study was to estimate the prevallence of osteopenia and osteoporosis in perimenopausal women, and to assess determinants of low one mineral density (BMD). All women born between 1941 and 1947 (aged between 46 and 54 years) living in the city of Eindhoven were invited to participate in the study; 5896 white Dutch women, representing $73 \%$ of the total number of Dutch women in this age group, were studied. Of these, $24 \%$ were using estrogen preparations and $19 \%$ had undergone hysterectomy, with or without oophorectomy. All women were interviewed and bone mineral density (BMD) of the lumbar spine was measured by 
dual energy $X$-ray absorptiometry (DXA). Osteopenia and osteoporosis were defined according to the criteria proposed by a WHO working group. In the population studied the prevalence of osteopenia and osteoporosis was $27.3 \%$ and $4.1 \%$, respectively. With progression from premenopause to menopause, the prevalence of osteoporosis increased from $0.4 \%$ to $12.7 \%$, and that of osteopenia from $14.5 \%$ to $42.8 \%$. An increased risk for low BMD (osteopenia and osteoporosis) was associated with age, menopausal status, and smoking while alcohol consumption, high body mass index (BMI) and use of estrogens had a protective effect. This study of a large population-based cohort of perimenopausal women revealed a high prevalence of low bone mass and, therefore, a higher risk for osteoporotic fractures.

The data further suggest that, when issues on the long-term efficacy and safety of preventive treatments are resolved, it may be possible to identify women at higher risk who are most likely to benefit from screening strategies.

Chapter 3 deals with the results of the EPOS study concerning menopausal complaints. At the onset of the climacteric healthy middle aged women present with a variety of complaints, especially in general practice. In these first years of entering the menopause, vaginal blood loss alters from irregular periods to complete amenorhoea. According to these different menstrual patterns we can distinguish a pre-, peri- and postmenopausal phase. We tried to assess whether specific climacteric complaints are related to these different phases. All women aged $47-54$ years, living in the city of Eindhoven were invited to participate in the Eindhoven Osteoporosis Study (EPOS); 6648 (78\%) agreed to participate. All women completed a questionnaire concerning climacteric complaints. Climacteric status was defined by menstrual history. Odds ratios were obtained for the relationship between climacteric status and climacteric complaints. Multiple logistic regression analysis was carried out, with climacteric status as the dependent varim able.

Of the 27 items in the questionnaire conceming climacteric complaints, 7 were significantly different between all three climacteric phases $(p<0.1)$. After multiple logistic regression analysis, comparing peri - and premenopause, only flushing (OR 5.9) was significantly different. Between post-and perimenopause 7 symptoms appeared to be different: three urogenital complaints (vaginal dryness (OR 1.6). vaginal discharge (OR 0.4 ) and pain during intercourse (OR $1.9 \mathrm{~h}$ ), three vasomotor symptoms: (day sweating (OR 1.4), night sweating (OR 0.7) and flushing (OR 1.9)) and finally insomnia (OR 1.3). When comparing post- and premenopause, flushing (OR 13.4), insomnia (OR 2.1) and depressed mood (OR 0.6) were significantly different, beside three urogenital symptoms: vaginal dryness (OR 2.6), vaginal discharge (OR 0.3 ) and pain with intercourse (OR 2.1). The major findings of the study are that flushing is strongly associated with the transition from pre- to perimemopause while urogenital complaints, day sweating and insomnia are more prominent in the transition from peri- to postmenopause. 
Chapter 4 presents the results of the EPOS study about the use of hormone substitution around menopause. It is suggested that during menopausal transition. women with vasomotor symptoms beneft from HRT (Hormone Replacement Therapy) whereas the use of HRT for other cognitive / vegetative symptoms is questionable. The occurrence of menopausal complaints and depressive symptoms was assessed cross-sectionally in 5896 Dutch Caucasian women of a large community sample in the city of Eindhoven the Netherlands (47-54 yrs). Menopausal complaints were assessed using a 22 items self-rating scale (consisting of a vasomotor -, uro-genital - and a cognitive/vegetative subscalel. Depressive symptoms were assessed using the Edinburgh Depressian Scale (EDS). Differences in mean scores were analysed between groups using ANOVA. The independent relationship of depressive symptoms to the intensity of menopausal complaints was assessed by multiple linear regression analysis. Women using HRT showed the highest scores on all subscales.

Oral contraceptive users had significantly lower scores on the vasomotor subscale compared to HRT users and to non-users. Depressive symptoms contributed the most to the explained wariance on scores on the menopausal subscales. We conclude that women during menopause presenting with several complaints of other than vasomotor origin might be suffering from underlying depression which makes it questionable to prescribe HRT for the latter symptoms.

In Chapter 5 deals with the results of the cross-sectional EPOS study about the characteristics of perimenopausal women using benzodiazepines. We investigated the extent to which benzodiazepine (BZD) use is associated with depression and perimenopausal complaints and took sociodemographic characteristics, life style factors and the use of other medication into account. The occurrence of benzodiazepine-use, menopausal complaints and depressive symptoms was assessed cross-sectionally in 5896 Dutch Caucasian women (47-54 years of age) of a large community sample in the city of Eindhoven, The Netherlands. Menopausal complaints were assessed using a 27 item self-rating scale. Depresivive symptoms were assessed using the Edinburgh Depression Scale (EDS) Benzodiazepine-use was defined as taking BZD on prescription in the two weeks before completing the questionnaires. BZD users showed significant differences in EDS scores $\geq 1215 \%$ versus $19 \%$, educational level, divorce, daly alcohol use $(31.3 \%$ versus $19.5 \%$ ). current smoking (37.7\% versus. $23.7 \%$ ), use of several medications, menopausal complaints, hysterectomies and/or ovariectomies, and one-child families. In multiple logistic regression analysis, smoking $(O R=1,7)$, estrogen use (OR=1.5) and depression score $(O R=4.6)$ were significant determinants of $B Z D$ use. Increasing depression scores were significantly associated with the use of $B Z D$ and other kinds of medication such as antidepressants, painkillers, gastric medication and estrogens. We found that the health status of perimenopausal women using BZD is worrying for several reasons. Depression score is the main determinant of $B Z D$ use. High drug intake and poor life style habits are significantly more common in 
$B Z D$ users. We hypothesize that the recognition and appropriate treatment of depression will contribute to a decreased BZD use and to an improvement in the physical, mental and social functioning of these women.

in Chapter 6 we present the results of a longitudinal follow up of a large randomly sampled population based cohort of women around menopause in which we tried to determine whether depressive symptomatology in healthy women is independently related to menopausal transition. Prevalence of depression is suggested to be substantialy higher in women around menopause. Declining estrogen levels might be an explanation. A large cohort of women was followed during 3.5 years (SD 0.4 ). Depressive symptomatology was assessed using the Edinburgh Depression Scale (EDS). Independent relationship between an intra- individual change in EDS score during the follow-up period and menopausal transition was analysed. All caucasian women born between 1941 and 1947, living in the city of Eindhoven the Netherlands were invited to take part in a screening program ( $n=8098$ ) of whom $78 \%$ participated $(n=6648) .92 \%$ returned the questionnaires of which $81 \%(n=4975)$ was fully completed. Women using estrogens and/or having undergone hysterectomy and/or ovariectomy were excluded (43.6\%). Of the remaining 2820 women, after 3.5 years, 2748 returned another postal questionnaire, of which $76 \%$ was fully completed $(n=2103)$. Beside the classical determinants of depression (unemployment OR $3.1, \mathrm{Cl} 1.6-5.8$, inability to work OR 1.7, CI 1.0-2.8, financial problems OR 2.9, CI11.1-7.3 death of a partiner OR 2.6, CI 1.1-6.1, death of a child OR 5.9, Cl 1.1-32.1 and a previous episode of depression OR 2.0, C 1 1.5-2.7) transition from peri- to postmenopause was significantly related to a high increase $(>5.4)$ of the EDS score $1 O R 1.8, \mathrm{Cl}$ 1.5-2.7). Only the transition from peri- to postmenopause seems to be independently related to a high increase of depressive symptomatology. This suggests that the complete ceasing of ovarian estrogen production rather than dedining estrogen levels is a risk factor for depressive symptomatology.

In chapter 7 the results of a cross-sectional study examining the relationship between auto-immume thyroid disease and depression in perimenopausal women is presented. 583 Perimenopausal women were randomly selected from a community cohort of 6846 women. Thyroid function (TSH, TT4 and TPO-Ab) and depression (using the Edinburgh Depression Scale) were assessed together with other determinants of depression. Several idependent thyraid related and psychosocial variables were entered into a multiple logistic regression analysis, using an EDS score $\geq 12$ as the dependent variable. The occurrence of financial problems, caring for parents, a previous episode of depression, the occurrence of e major life event and an elevated concentration of TPO-Ab $(\geq 100 \mathrm{U} / \mathrm{ml})(\mathrm{OR} 3.0)$ were all significantly and independently related to depression. Up to $10 \%$ of fertile women have elevated levels of TPO-Ab, and once an individual is TPO-AB positive, he or she will tend to remain so for the rest of his/her life and will be of high risk of developing clinical thyroid dysfunction in the future. Thyroid function 
(either clinical or sub clinical) was not related to depression and neither was menopausal status. We conclude that depression, although not related to menopausal status, has a high prevalence in perimenopausal women in the community. The psycho-social determinants are no different from those found for depression in general. The presence of one biological marker (TPO-Ab) is associated with, and may many women more vulnerable for, depression.

Chapter 8 . In our population-based survey we carried out successive investigations into the areas of osteoporosis, menopausal complaints, medicine use, depression and thyroid dysfunction.

The main results of the present study are presented according to the aims and study questions.

The strength and limitations are discussed. We summarize the learning points of the present study and possible implications for general practice are formulated. In addition conclusions and recommendations for future research are given. 


$$
\text { : }
$$

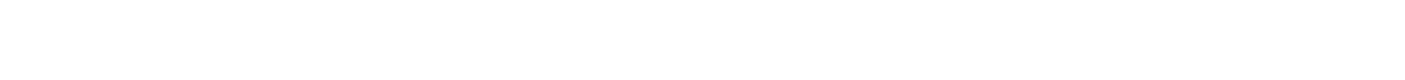
政 


\section{Samenvatting}

Hoofdstuk 1 geeft een inleiding over de uitgebreide, maar vaak vage klachten. waarmee de huisarts geconfronteend wordt door vrouwen in de leeftijd rondom de overgang. Hoewel het bestaan van een "menopauzaal syndroom" niet langer reëel wordt geacht, wordt nog steeds, zowel in medische als in populair-wetenschappelijke literatuur, de menopauzale vrouw gezien als lijdend aan een aanzienlijke hoeveetheid klachten. In deze inleiding wordt de context van de Eindhovense Perimenopauzale Osteoporose Studie uit de doeken gedaan. Door middel van uitgebreide vragenlijsten, DEXA metingen en bloedmonsters werden zeer velle (gedetailleerde) gegevens werzameld. Met behulp van deze gegevens werd getracht een antwoord te geven op de volgende vragen:

1. Wat is de prevalentie van osteoporose en osteopenie bij vrouwen rond de overgang en wat zijn de belangrijkste determinanten van een lage botmineraaldichtheid.

2. Zijn er verschillen in het voorkomem en/of de intensiteit van uit de literatuur bekende overgangsklachten, als men de drie verschillende menopauzale fasen (pre-, peri-en pastmenopauze) met elkar vergelijkt?

3. Bestaat er verband tussen de verschillende, vaak vage, klachten zoals die gepresenteerd worden rondom de overgang en dalende oestrogeenspiegels? Is er verband met oestrogeengebruik? Bestaat er verband tussen menopauzale klachten en depressieve symptomatologie?

4. Worden benzodiazepines tijdens de overgang gebruikt voor specifieke klachten, wat zijn de karakteristieken van de gebruiksters en wat zijn de determinanten die het gebruik wan benzodiazepines beirnvloeden?

5. Bestaat er verband tussen de overgang van pre- naar peri-en postmenopauze en depressieve symptomatologie en wat is de invloed van andere determinanten?

6. Depressie kan worden veroorzaakt door een onderliggende klinische hypothyreoidie. Het voorkomen van "stressfull life-events" (hetgeen een belangrijke determinant is wool het ontstaan van depressie) is een risicofactor voor de ontwikkeling van schildklierfunctie stoornissen. Bestaat er een relatie tussen depressiviteit en een auto-immuun schildklierziekte?

In hoofdstuk 2 worden de resultaten gepresenteerd van een cross-sectionele studie. Het doel van deze studie was het meten wan de prevallentie van asteopenie en osteoporose bij perimemopauzale vrouwen en daarnaast het vaststellen van de determinanten die kunnen leiden tot een lage botmineraaldichtheid (BMD). Alle vrouwen geboren tussen 1941 en 1947 (met een leeftijd tussen de 46 en 54 jarr) en wonende in de stad Eindhoven werden witgenodigd om deel te nemen aan de EPOS studie. 5896 Blanke Nederlandse vrouwen werden bestudeerd, hetgeen 
representatief is voor $73 \%$ van het total alanal Nederlandse vrouven in deze leeftijdscategorie.

Van de groep gebruikte $24 \%$ oestrogenen en had $19 \%$ een uterusextirpatie ondergaan (met of zonder ovariectomie). Alle wrowwen werden geinterviewd en ondergingen een botdichtheidsmeting (DEXA) van de lumbale wervelkolom. Osteopenie en osteoporosis werden gedefinieerd conform de door de WHO werkgroep voor osteoporose voorgestedde criteria. In de bestudeerde populatie was de prevalentie van osteopenie en osteoporose respectievelijk $27,3 \%$ en 4,1\%. Als de premenopauze overgaat in de menopauze neemt de prevalentie van osteoporose toe van $0,4 \%$ naar $12,7 \%$ en de prevalentie van osteopenie van $14,5 \%$ naar $42,8 \%$. Het toegenomen risico op een lage botdichtheid is gerelateerd aan leeftijd, menopauzale staat en roken terwijl alcoholconsumptie, een hogere body mass index en het gebruik van oestrogenen een beschermend effect hebben. Deze grote cohort-studie van perimenopauzale vrouwen op populatieniveau toont een hoge prevalentie van lage botdichtheid. Daarmee bestaat er een verhoogd risico op het ontstaan van osteoporotische fracturen.

De gegevens laten voorts zien dat, als de effectiviteit en veiligheid van preventieve behandeling op langere termin kan worden gewaarborgd, het mogelijk zou kunnen zijn risicogroepen te identificeren die zeer waarschijnlijk gebaat zijn bij screeningsonderzoek.

Hoofdstuk 3 galat over de resultaten van de EPOS studie met betrekking tot overgangsklachten. Aan het begin van het climacterium worden in de huisartsenpraktijk door gezonde vrouwen van middelbare leeftijd een grote diversiteit aan klachten gepresenteerd. Aan het begin van de climacteriële leeftijd verandert het menstruatiepatroon van onregelmatige perioden van vaginaal bioedverlies naar een volledige amenorhoe. Op geleide van deze verschillende menstruatie patronen onderscheiden we 3 menopauzale fasen: pre-, peri- en postmenopause.

In deze studie hebben we geprobeerd wast te stellen of er specifieke menopauzale klachten horen bij de te onderscheiden menopauzale fasen. Ale vrouwen wit de stad Eindhoven in de leeftijd van $47-54$ jaar werden uitgenodigd mee te doen aan de EPOS studie; 6648 vrouwen $(78 \%$ ) stemden toe ir deelname en vulden een vragenlijst over overgangsklachten in. De menopauzale fase werd vastgesteld aan de hand van het menstruatiepatroon. Odds ratio's werden berekend voor de relatie ussen de menopauzale fase en de verschillende overgangsklachten. Multipele logistische regressie werd uitgevoerd met de menopauzale fase als athankelijke warlabele. Van de 27 items in de vragenlijst die betrekking hadoen op overgangsklachten bleken er 7 significant te verschillen tussen alle drie de te onderscheviden menopauzale fasen $(p<0,1)$. Na multipele logistische regressie was, bil vergeliking van peri. en pre-menopauze alleen flushing significant werschillend (OR 5,9). Tussen post- en peri- menopauze bleken 7 symptomen significant verschillend: drie urogenitale klachten (vaginale droogheid (OR 1,6), vaginale afscheiding (OR 0,4 ) en pijn bij gemeenschap (OR 1,9)), drie vasomotore klachten 
(dagzweten (OR 1,4), nachtzweten (OR 0,7) en opvliegers (OR 1.9) en tenslotte slapeloosheid (OR 1,3). Als we post-en pre-menopauze met elkaar verge ijken zijn opviegers (OR 13,4), slapeloosheid (OR 2,1) and depressieve stemming (OR 0,6) significant verschillend naast 3 urogenitale klachten: vaginale droogheid $(\mathrm{OR} 2,6)$ vaginale afscheiding $(O R \quad 0,3)$ en pijn bij samenleving (OR 2,1). De belangrijkste resultaten van deze studie zinn dat opvliegers een sterke relatie vertonen met de overgang van pre- naar peri-menopauze terwij urogenitale klachten, dagzweten en slapeloosheid duidelijker aanwezig zijn bij de overgang van peri- naar post-menopauze.

In Hoofdstuk 4 worden de resultaten van de EPOS studie over het gebruik van hormaonsubstitutie (HRT) rond de overgang gepresenteend. Er wordt verondersteld dat gedurende de overgang vrouwen met vasomotore klachten baat hebben bij HRT, terwill het nut van HRT woor het bestrijden cognitief Negetatieve klachten word betwijfeld. Het voorkomen van menopauzale klachten en van depressieve symptomatologie werd cross-sectioneel gemeten bij 5896 blanke Nederlandse vrouwen in de leeftijd van 47 tot 54 jaar in een bevolkingsonderzoek in de stad Eindhoven. Menopauzale klachten werden onderzocht door middel van een 22 items tellende zelfwaarderingschaal. Deze items werden onderverdeeld in 3 subschalen, te weten: een vasomotore - een urogenitale- en een cognitief / vegetatieve subschaal. Depressieve symptomatologie werd gemeten met de Edinburgh Depression Scale (EDS). Verschillen tussen de gemiddelde scores van de verschillende groepen werden geanalyseerd door middel van ANOVA. De onathankelike relatie tussen depressieve symptomatologie en de intensiteit van menopauzale klachten werd berekend door gebruik te maken van multipele lineaire regressie analyse. Vrouwen die HRT gebruikten lieten de hoogste scores op alle subschalen zien. Vrouwen die orale anticonceptiva gebruikten hadden significant lagere scores op de vasomotore subschaial vergeleken met gebruiksters van HRT en vergeleken met vrouwen die geen oestrogenen gebruikten. Depressieve symptomatologie leverde de grootste bijdrage aan de gevonden variantie op de scores van de menopauzale subschalen. De conclusie van deze studie is dat vrouwen die gedurende de overgang andere klachten presenteren dan de typische vasomotore symptomen mogelijk lijden aan een onderliggende depressie. Deze bevinding roept de vraag op of het voorschrijven van HRT woor cognitief/vegetatieve klachten zinvol is.

Hoofdstuk 5 behandelt de resultaten wan de EPOS studie over het bestuderen van de karakteristieken van wrouwen rondom de overgang die benzodiazepines (BZD) gebruiken. We onderzochten in welke mate benzodiazepinegebruik in verband kan worden gebracht met depressiviteit en perimenopauzale klachten en we hielden daarbij rekening met demografische gegevens, life-style factoren en het gebruik wan medicatie. Het voorkomen van benzodiazepine-gebruik, menopauzale klachten en depressieve symptomatologie werd vastgelegd in een cross-sectioneel bevolkingsonderzoek onder 5896 blanke Nederlandse vrouwen 
in de leeftijd van 47 tot 54 jaar wonend in de stad Eindhoven. Menopauzale kachten werden gemeten middels een 27 items telende zelfwalarderingschaal en depressieve symptomatologie met de Edinburgh Depression Scale. Benzodiazepinegebruk werd gedefinieerd als gebruik wan benzodiazepines op recept in de twee weken woorafgaand aan het invullen van de vragenijsten. BZD gebruiksters vertoonden significante verschillen ten opzichte van niet-gebruiksters: vaker EDS scores $\geq 12$ ( $51 \%$ versus $19 \%$ bij niet gebruiksters), meer lager opgeleiden, meer dagelijks alcoholgebruik $(31,3 \%$ versus $19,5 \%)$, vaker roken $(37,7 \%$ versus $23,7 \%$ meer gebruk van diwerse soorten medicatie, meer menopauzale klachten, vaker uterusextirpaties en meer een-kind gezinnen.

Bij multipele logistische regressie analyse bleken roken (OR 1,7 ), oestrogeengebruk (OR 1,5) en depressiescore (OR 4,6) onafhankelijke significante determinanten voor BZD gebruik. Oplopende depressiescores bleken een significante relatie te hebben met een toegenomen gebruik van $B Z D$ en andere soorten medicatie zoals antidepressiva, pijnstillers, maagmiddelen en oestrogenen. In deze studie vonden we dat de gezondheidstoestand van vrouwen rond de overgang die BZD gebruiken om verschillende redenen zorgwekkend is. De depressie score is de belangrikste determinant van BZD gebruik. Een hoog medicijngebruk en een slechte leefgewoonte komen significant vaker voor bij BZD gebruiksters. Wij weronderstellen dat herkenning en adequate behandeling van depressiviteit zal bijdragen tot een vermindering van BZD gebruik en een verbetering van het fysiek, geestelijk en sociaal functioneren van vrouwen rond de overgang.

In hoofdstuk 6 vindt $u$ de beschrijving van een gerandomiseerd longitudinaal bevolkingsonderzoek in een cohort van wrouwen rond de overgang, waarin getracht wordt vast te stellen of de overgang bij gezonde vrouwen een onafhankelijke relatie vertoont met depressieve symptomatologie. Er wordt verondersteld dat de prevalentie van depressiviteit bij vrouwen rondom de overgang duidelik hoger ligt dan in eerdere fasen van het leven.

Een groot cohort vrouwen werd gevolgd gedurende een periode van 3,5 jaar (SD 0.4). Depressieve symptomatologie werd gemeten door middel van de Edinburgh Depression Scale (EDS). Er werd een analyse gedaan van de onafhankelike retatie tussen de intra-individuele verandering van de EDS score en de verandering wan menopauzale tase. $78 \%$ Van alle blanke Nederlandse vrouwen in de leeftijd van 47 tot 54 jaar en wonend in de stad Eindhoven $(n=8098)$ nam deel aan een screeningsprogramma $(n=6648) .92 \%$ stuurde de vragenlijsten terug waarvan $81 \%(n=4975)$ volledig was ingevuld. Vrouwen die een uterusextirpatie en/of ovariectomie hadden ondergaan (43\%) werden uitgesloten van de studie. Van de resterende 2820 vrouwen stuurden na 3.5 jaar 2748 vrouwen per post een tweede vragenlijst terug waarvan $76 \%$ volledig was ingevuld $(n=2103)$. Behalve de klassieke determinanten van depressie (werkeloosheid (OR 3,1), arbeidsongeschiktheid (OR 1.7), financiële problemen (OR 2,9), overlijden van partner (OR 2.6), overlijden van een kind (OR 5,9) en een eerdere periode van depressiviteit (OR 
2.0) vertoonde de overgang van peri- naar post-menopauze een significante relatie met een hoge toename wan de $\operatorname{EDS}$ score $(>5,4)$ (OR 1,8$)$. Daar alleen de overgang van peri- naar postmenopauze deze relatie vertoond wordt daarmee gesuggereerd dat het volledig staken van de ovariêle oestrogeenproductie eerder dan een lager wordende oestrogeenspiegel een risicofactor is wor depressieve symptomatologie.

In hoofdstuk 7 worden de resultaten weergegeven van een cross-sectionele studie die de relatie bestudeert tussen auto-immun schildklierziekte en depressiviteit bij vrouwen rond de overgang. Bij 583 willekeurig geselecteerde vrouwen uit een populatiecohort van 6848 vrouven werden schildklierfuncties gemeten (TSH. fT4 en TPO-Ab) tegelijk met een depressiviteitsscore (door middel van de Edinburgh Depression Scale) en een aantal andere determinanten van depressie. Verschillende onathankelijke schildklier gerelateerde variabelen en psychosociale variabelen werden gebruikt voor een multipele logistische regressie analyse, waarbij een EDS score $\geq 12$ de afhankelike variabele was. Het bestaan van financiële problemen, zorg voor een of beide ouders, een eerdere periode van depressiviteit, het voorkomen van een "major life event" en een verhoogde concentratie van TPO-Ab ( $2100 \mathrm{U} / \mathrm{ml}$ ) (OR 3,0) bleken allemaal onafhankeljik en significant in verband te staan met een verhoagde EDS 5core. Rond $10 \%$ van de vruchtbare vrouwen heeft een verhoogde TPO-Ab spiegel en als een individu eenmaal positief is voor TPO-Ab dan zal dat de rest van zijn of haar leven zo blijven. Deze personen zullen een verhoogde kans hebben op het ontwikkelen van een klinische of subklinische schildklierfunctiestoornis in de toekomst. De schildklierfunctie (klinisch of subklinisch) vertoonde geen relatie met depressiviteit net zo min als menopauzale status. We concluderen dat depressiviteit in een bevolkingsonderzoek bij vrouwen, hoewel niet gerelateerd aan menopauzalle status, een verhoogde prevalentie rondom de overgang. De psychosociale determinanten verschillen niet van die determinanten die gevonden worden bij een depressie in zijn algemeenheid. De aianwezigheid van een biologische marker (TPO-Ab) vertoont een relatie met en zal vele vrouwen meer bevattelijk maken voor, depressiviteit.

Hoofdstuk 8 . In ons bevolkingsonderzoek slaagden we erin op succeswolle manier gegevens te verzamelen op het gebied van osteoporose, menopauzale klachten, medicingebruik, schildklierfunctiestoornissen en depressie. De belangrijkste resultaten van deze studie worden in antwoord op de onderzoeksuragen in dit hoofdstuk weergegeven. De beperkingen maar ook de kracht van het onderzoek worden besproken. Tenslotte worden de leerpunten samengevat en worden aanbevelingen gedaan voor toekomstig onderzoek. 
Ceachte metrouw,

patiê̈nt nummer:

Wij weten dat u mogelijk een deel van de volgende wragen tijdens uw bezoek al heeft beantwoord. Zou u desondanks zo wriendelijk willen zijn alle vragen in te vullen?

Hierdoor krijgen wij een beter inzicht hoe vrouwen zich rondon de owergang woelen.

Het zal ons erg veel helpen om de wragen van vrouwen over hum gezondheid beter te kunnen beantwoorden.

Zoals beloofd in de brief worden de gegevens volledig vertrouwelijk verwerkt, zij vallen onder het medisch geheim.

\section{A. Overgangsklachten.}

Wij willen u graag enkele wragen stellen over typische overgangsklachten, zoals opwliegers en z:weetaanvallen.

Een opvlieger is een plotseling abrupt gevoel van hitte, met of zonder zweten.

Een zweetaanval is je zweterig en warm voelen, geen plotseling abrupt gevoel van hitte.

1. Hoeveel nachten bent u afgelopen week zwetend wakker geworden?
$\mathrm{O}$ geen één nacht, ga naar vraag $\mathrm{A}^{3}$
$O$ vier nachten
$\mathrm{O}$ tên nacht
O wijif nachiten
O twee nachten
O zes nachten
O drie nachten
$\mathrm{O}$ elke nacht van deze week

2. Werd u de afgelopen week wel eens meerdere keren op één nacht $z$ wetend wakker?

O nee

$\mathrm{O}$ ja nachten per week.

3. Hoeweel dagen heeft u overdag opvliegers gehad in de afgelopen week?
$O$ helemaal geen opvliegers gehad
$O$ wier dagen
overdag., ga naar vraag $A 6$
O wijf dagen
O eén dag
O zes dagen
O twee dagen
$\mathrm{O}$ elke dag van deze week
O drie dagern

4. Howeel opwliegers had u gemiddeld overdag in de afgelopen week?
$\mathrm{O}$ ik heb helemaal geen opvliegers
O 5-6 opvliegers per dag gehad overdag, ga naar vraag A6
O $7-8$ opvliegers per dag
O soms geen, soms tén per dag
O 9-10 opuliegers per dag
O 1-2 opvliegers per dag
0 meer dan 10 opvliegers per dag
O $3-4$ opvliegers per dag

5. Wat was de afgelopen week thet thoogste aantal opvliegers op één dag? opvliegers op eén dag. 
6. Hieronder wolgen een aantal woorbeelden wan klachten die kumen voorkomen rondon de overgang. Wilt u woor elk van de onderstaande klachten aangeven, in hoeverre $u$ hiervan de afgelopen 4 weken last heeft gehad? S.w.p. een cirkel platsen rondon het antwoord dat het meeste van toepassing is.

\begin{tabular}{|c|c|c|c|c|}
\hline & geen & weinig & matig & veell \\
\hline - tintelingen ................................. & 1 & 2 & 3 & 4 \\
\hline - duizeligheid ................................ & 1 & 2 & 3 & 4 \\
\hline - 's nacluts zweten ........................... & 1 & 2 & 3 & 4 \\
\hline - zweten overdag .............................. & 1 & 2 & 3 & 4 \\
\hline - obstipatie (moeilijke stoelgang) ............. & 1 & 2 & 3 & 4 \\
\hline - diarree $\ldots \ldots \ldots \ldots \ldots \ldots \ldots \ldots \ldots \ldots \ldots \ldots \ldots \ldots \ldots \ldots \ldots$ & 1 & 2 & 3 & 4 \\
\hline - pijn in spieren of gewrichten .............. & 1 & 2 & 3 & 4 \\
\hline - gebrek aan zelfvertrouwen................. & 1 & 2 & 3 & 4 \\
\hline - hartkiloppingen...$\ldots \ldots \ldots \ldots \ldots \ldots \ldots \ldots \ldots \ldots$ & 1 & 2 & 3 & 4 \\
\hline - droge vagina.................................. & 1 & 2 & 3 & 4 \\
\hline - jeuk aan de schaamlippen................... & 1 & 2 & 3 & 4 \\
\hline - vaginale afscheiding........................... & 1 & 2 & 3 & 4 \\
\hline - branderig gevoel bij het plassen............ & 1 & 2 & 3 & 4 \\
\hline - ongewild urine verlies......................... & 1 & 2 & 3 & 4 \\
\hline - pijn bij de gemeenschap...................... & 1 & 2 & 3 & 4 \\
\hline - warmte niet kunnen verdragen ............. & $\mathbb{1}$ & 2 & 3 & 4 \\
\hline - kou niet kunnen verdragen................... & 1. & 2 & 3 & 4 \\
\hline 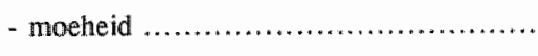 & 1 & 2 & 3 & 4 \\
\hline - kortademigheid................................. & 1 & 2 & 3 & 4 \\
\hline - opvliegers........................................... & 1 & 2 & 3 & 4 \\
\hline - gejaagdheid ....................................... & $\mathbb{1}$ & 2 & 3 & 4 \\
\hline 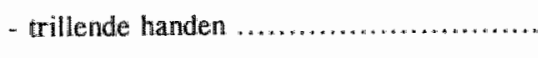 & 1 & 2 & 3 & 4 \\
\hline droog haar......................................... & 1 & 2 & 3 & 4 \\
\hline 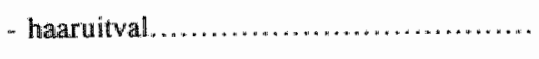 & 1 & 2 & 3 & 4. \\
\hline - een droge huid. ................................ & 1 & 2 & 3 & 4 \\
\hline moeite met concentreren ..................... & 1 & 2 & 3 & 4 \\
\hline 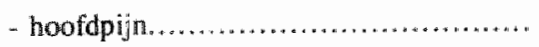 & 1 & 2 & 3 & 4 \\
\hline
\end{tabular}


Hieronder wolgen nog een aantal voorbeelden van klachien die kunnen voorkomen rondom de overgang. Wilt u woor elk wan de onderstaande klachien aangeven, in hoeverre u hiervan de afgelopen 4 weken last heeft gehad? S.v.p. een cirkel plaatsen rondom het antwoord dat het meestic van toepassing is.

\begin{tabular}{|c|c|c|c|c|}
\hline & geen & weinig & matig & weel \\
\hline . moe bij het opstaan.......................... & 1 & 2 & 3 & 4 \\
\hline - prikke baarheid.................................. & 1 & 2 & 3 & 4 \\
\hline - vergeetachtigheid ................ & 1 & 2 & 3 & 4 \\
\hline - moerte net inslapen......................... & 1 & 2 & 3 & 4 \\
\hline - gewichtsverlies .............................. & 1 & 2 & 3 & 4 \\
\hline - het plotseling koud hebben............... & 1 & 2 & 3 & 4 \\
\hline - neersiachtigheid ......................... & 1 & 2 & 3 & 4 \\
\hline - migraine ....................................... & $\rrbracket$ & 2 & 3 & 4 \\
\hline 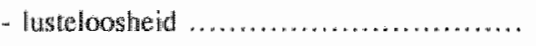 & 1 & 2 & 3 & 4 \\
\hline - 's nachts wakker worden .................. & 1 & 2 & 3 & 4 \\
\hline - rusteloos gevoel in de benen ............. & 1 & 2 & 3 & 4 \\
\hline 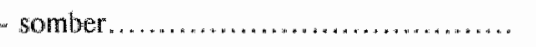 & 1 & 2 & 3 & 4 \\
\hline - toegenomen gewicht,............ & 1 & 2 & 3 & 4 \\
\hline - opgeblazen gevoel.......................... & 1 & 2 & 3 & 4 \\
\hline - verminderde eetlust ......................... & 1 & 2 & 3 & 4 \\
\hline 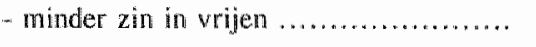 & 1 & 2 & 3 & 4 \\
\hline - rugpijn..................................... & 1 & 2 & 3 & 4 \\
\hline - angstig zijn, gespannen. & 1 & 2 & 3 & 4 \\
\hline - paniekaaa nwallen hebben .................. & 1 & 2 & 3 & 4 \\
\hline - minder interesse in dingen hebben ....... & 1 & 2 & 3 & 4 \\
\hline - snel bezorgd zijn . ........................... & 1 & 2 & 3 & 4 \\
\hline - cen toegenomen eetlust hebben ........... & 1 & 2 & 3 & 4 \\
\hline - afgenomen zelfwaardering................... & 1 & 2 & 3 & 4 \\
\hline
\end{tabular}




\section{B. Stemming en Gevoel.}

De volgende vragen bebben betrekking op boe a zich de afgelopen 7 dagen beft gevold. Onwirkel dat antwoord dat her beste aangeeff hoe u zich voelde. Per vrag is slechis il antwoord mogetijk.

1. Ik heb kurwen lachen en ae leuke kant van de dingen kninnen inuien:

1. woweel als ik altijo kon.

2. viet zo veel au als anders

3. weker niet zo veel mals anders

4. helernaal nier.

2. $l k$ heb met plezier nar dingen uitgekeken:

1. Zo alls altijd of meer

2. wat minder dan ik gewend was

3. absolusuli minder dan ik gewend was

4. nanwelijks.

3. Ik heb mijelf onmodig verwijten gernakak als at iets fout ging:
1. ja, heel valak
2. jă, soms
3. niet erg vark
4. nee, nooir

4. Ik: ben bang of bazorgd geweest zonder dat er sen aanle ding was:
2. natwelijks
3. ja, soms

1. nee. helemaal nie

4. ja, zeer vank

5. If reageerde schrikachtig of paniekerig zonder echt goede neden:
1. ja, tameli ik valk
2. ja, soms
3. net, quet valak
4. nooit

6. De dingen groeiden mij bowen luet hoofd:

1. Ja, meestal was ik er niet tegen opgewassen

2. ja, soms was ik ninder goed tegen dingen opgewassen dan anders.

3. nee, meestal kon ik de dingen erg goed aan

4. nee, ik kon alles even goed aan als anders:

7. Ik woelde mij zo ongelukkig dat ik er bjjua nel van kon stapen:
1. ja, meestal
2. ja, soms
3. rie? vaak
4. thelemaal niet

8. Ik wolde mily scomber en betord:
1. jas bijin sieeds
2. jak, tamelijk watak
3. miet erg vaak
4. nee, belematal wiet

9. Ik was zo ongelukkig dat ik heb zitten lutillen:
1. 艇, heel vas
2. Ja, tamelifk waak
3. alleem af en toe
4. neee, novit

10. Wheb er ana gedacht mijelf iets an te doen:

1. ja , tamelijk valk

2. soms

3.

4. nowit 


\section{Bewegen en Sport.}

1. Beocfont u momented wery sport?

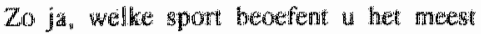
frequient"

In welk jatar but u met deze sport begonnen?

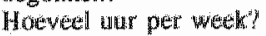

Hoveret maanden per jaar?

Wel of nut bij exs sportwerenging?

Op well nivo?

2. Als th een rweede spont beoefent, welke sport is dat?

In wellic jaar bent u met deze sport begonnen?

Hoevet uur per week?

Hoeved maand en per jaar?

Wel of nitet bij ean sportwereniging?

Op welk nivo?

3. Heeft u vroeger gesport?

$20 \mathrm{ja}$ wellke sport beofende $\mathrm{t}$ het meest frequent?

In welk jas bent u met deze sport begonnen?

In welk jaar bent a met deze sport opgehouden?

Hoeveel urir per week?

Hoeveel matander" per jation?

Wol of niet bu een spontwerniging?

Op welk nivo?
O ja

$\mathrm{O}$ nee, ga nat vraag $\mathrm{C} 3$

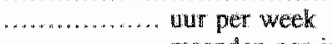

O sportverenging

nidanden per jas

$\mathrm{O}$ ongeorganiseend

O recreatief

O competitieverband

$\mathrm{O}$ (semi)top uur per week

- maanden per jaar

$\mathrm{O}$ wel bij ean sportwereniging

$\mathrm{O}$ niet bij een sportvereniging

$O$ recreatief

O competitieverband

$O$ (semi)top

$\mathrm{O}$ ja

O nee, ga navar vraag 06 .

wur per week

masuden per jazr

$O$ wel bij en sportverenging

$\mathrm{O}$ niet bij sen sportwereniging

O recreative

$\mathrm{O}$ competitieverband

O (semi)top 
4. Als theer sporten heeft beofend, welke sport was dat?

In welk jaar bent y met deze spori

begonnen?

In welk jaar bent u mat deze sport

opgehouden?

Hoeveel unt per week?

Hoevel maanden per jar.

Wel of niet bij een sportwereniging?

................. hutur per week

.......... manuden per jakt

$\mathrm{O}$ wel bij sen sportwereniging.

O niet bij een sportvereniging

Op welk nivo?

0 recreatief

O competitieverband

O (semi)top)

5. Als u meer dan twet sporten heeft beoetend, welke sport was dat?

In welk jaar bent a met dexe sport begomnen?

In welk jaar bent a met deze spont op-

gehouden?

Hoeveel wur per week?

Hoeveel maanden per jaar?

Wel of riet bij een spontvereniging?

................. vur per week matanden per jaur

$O$ wel bij tetn sportvereniging

$\mathrm{O}$ niet bij een sportveteniging

Op welk givo

O recteative

O competitiewerband

O sermitop

6. Hoeveel uren loopt/liep u gemiddeld per week naar het werk en/of naar de winkel?

Ongeveer uren per week voor uw $25^{\circ}$ jaar.

Ongeveer .......... uren per week na uw $25^{*}$ jaar.

7. Hoeveel uren van uw vrije tijd besteedt u per week in total aan bezigheden zoals, tuinieren, fietsen (niet wielrennen), wandelen, de hond uitlaten, klussen, huis opknappen., schoonmaken en reparaties?

Ongeveer.......... uren per week voor uw $25^{\circ}$ jaar.

Ongeveer .......... uren per week na un $25^{6}$ jaar. 


\section{Leefgewoonten: Eet-, drink-en rookgewoonte.}

Uit onderzoek is gebleken dat veell mensen min of meer geregeld zes of meer glazen alcoholhoudende drank per dag gebruilken.

1. Op hoeveel dagen per week gebruikt u gemiddeld genomen alcoholhoudende drank?
O 7 dagen per week
O 3 dagen per week
O 6 dagen per week
O 2 dagen per week
05 dagen per week
O 1 dag per week
O 4 dagen per week
O 0 dag per week, ga naar wraag D3

2. Als u op een dag alcohol drinkt, hoeveel glazen drinkt u clan gemiddeld?
N.B. hatve glazen naar boven afronden.
O 11 glazen of meer
O 3 glazen
07 a 10 glazen
O 2 glazen
06 glazen
O 1 glas
04 a 5 glazen

3. Rookt u nu sigaretten of wen andere vorm van tabak (asnkruisen wat voor u het meest wan toepassing is)?

O nee

O sigaretten $\quad$...... sig. per week ga nar wraag, DS

O sigaretten $\quad$...... sig. per dag ga naar vraag D5

O shag/zelfgerolde sigaretten ...... sig. per week ga naar wraag DS

O shag/zelfgerolde sigaretten ...... sig. per dag ga naar vraag D5

O sigaren $\quad$...... sig. per week ga naar wraag D5

O sigaren $\quad$....... sig. per dag ga naar vragg D5

4. Heeft u vroeger sigaretten of een andere vorm van tabak gerookt (aankruisen wat voor u het meest van toepassing is)?

$\mathrm{O}$ nee, nooit ga nal vraag $\mathrm{D} 8$

$\mathrm{O}$ sigaretten

O sigaretten $\quad$...... sig. per dag ga naar wraag D5

...... sig. per week ga natar vraag D5

O shag/zelfgerolde sigaretten ...... sig. per week ga naar vraag D5

O shag/zelfgerolde sigaretten ...... sig. per dag ga nat wraag D5

O sigaren

O sigaren

...... sig. per week ga natr vraag DS

...... sig. per dag ga naar wrag DS

5. Op welke leeftijd bent u begonnen met roken?

IK was toen .... jaar

6. Heeft u oolt bewtsist geprobeerd te stoppen met roken?

$\mathrm{O} \mathrm{ja}$

O nee, ga nar vraag D8

7. Bent u daarna weer gaan roken?

0 ja

O nee 
8. Rookt één van uw huisgenoten?

$\mathrm{O}$ ja
$\mathrm{O}$ nee

Welke aanduiding beschrijft het beste hoeveel melkprodukten u gebruikt heeft bij de verdere vemoemde periodes (denk hierbij oolk aan o.a. pap en vla):

9. Hoeveel melkprodukten gebruikt u voor uw $25^{\text {* }}$ jaar?

O 3 of meer glazen per dag (haast bij elke maaltijd)

O 1.2 glazen per dag (haast elke dag doch niet bij elke maaltijd)

$\mathrm{O}$ elke week maar niet elke dag

O minder dan één keer per week

Ogeen

10. Hoeveel melkprodukten gebruikte u ma uw $25^{\circ}$ jaar?

03 of meer glazen per dag (haast bij elke maaltijd)

O 1-2 glazen per dag (haasit elke dag doch niet bij elke maaltijd)

O elke week maar niet elke dag

$O$ minder dan én keer per week

$O$ geen

1. Komen er bij u in uw familie (wader, moeder, broer, zus) veel botbreuken voor (denk bijvoorbeeld ook aan breuken van heupen en wervels)?

O nee

O ja, bij

\section{E. Medicijngebruik.}

Medicijnen tijdens ziekenhuisopname hoeft u niet mee te rekenen. Onder medicijnen verstaan we alle middelen die u voor een aandoening gebruikt. Dit zijn bijwoorbeeld oolk poeders, zalf, druppeltjies en injecties. Wilt u ook de pil vermelden indien u dexe gebruikt?

1. Heeft u de laatste 14 dagen medicijnen gebruikt die zonder recept waren gekocht?

O nee, ga naar vraag E3

O ja 
2. Wat zin de namen van die medicijnen? Wilt u de naam zo nauwkeurig mogelijk noteren? Eventucel kunt u de verpakking radplegen.

3. Heeft $u$ de afgelopen 14 dagen medicijnen op recept gebruikt?

O nee, ga naar vraag FI.

O ja:

4. Wilt u deze medicijnen hieronder aankruisen?

O Pijn-en koorsiswerende middelen

O Medicijnen tegen hoest, werkoudheid, griep en keelpijn

O Middelen tegen bloedarmoede, zoals ijzertabletten

0 Versterkende middelen zoals vitaminen, mineralen en tonicum

O Medicijnen voor het hart of de bloedvaten

O Medicijnen voor de bloeddruk

O Medicijnen voor teen te hoog cholesterol

$\mathrm{O}$ bloedverdunnende middelen

O plaspillen

O laxeermiddelen (voor de stoelgang)

O medicijnen voor maag- en darmklachten

O slaap-en kalmeeringsmiddelen, middelen tegen de zenuwen

0 antibiotica, zoals penicilline en sulfapreparaten

O medicijnen voor de huid (bv jeugdpuistjes, eczeem, jeuk, roos, wonden)

O medicijnen voor reuma, gewrichtspijn enz.

$\mathrm{O}$ medicijnen tegen allergie

$O$ medicijnen tegen astma

O hormonen

$\mathrm{O}$ medicijnen tegen suikerziekte

O medicijnen voor de ogen (zalf, druppels)

$O$ de pil, namelijk

$\mathrm{O}$ andere medicijnen, namelijk 


\section{F. Opleiding en Beroep.}

1. We zijn geïnteresseerd in de hoogste opleiding die u met een diploma heeft afgesloten. Kunt u aangeven in welke categorie deze opleiding thuishoort? (én antwoord aankruisen)

O Lager onderwijgs (basisonderwijs).

O Lager beroepsonderwijs (LTS, LHNO, LEAO, huishoudschool, lagere land- en tuinbouwonderwijs enz:)

O Middelbaar algemeen onderwijs (LAVO, ULO, MULO, MAVO, 3-jar HBS enz.)

O Middelbaar beroeps onderwijs (MTS, MEAO, praktijkdiploma boekhouden, kleuterkweekschool enz.)

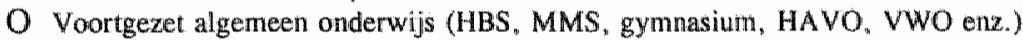

O Hoger beroepsonderwijs (HTS, HEAO, HHNO, sociale academie, lerarenopl enz.)

O Wetenschappelijk onderwijs (doctoraal/ ingenieursexamen enz.)

O Anders, namelijk

2. Volgt $u$ op dit moment een dag-(of avond-)opleiding? Zo ja, welke?

O nee

O ja, namelijk

3. Welke omschrijwing is op dit moment op u het meest van toepassing?

$\mathrm{O}$ ik heb een betaalde werkkring

$\mathrm{O}$ ik ben werkelloos (geregistreerd bij het GAB)

$\mathrm{O}$ ik ben arbeidsongeschikt ( $\mathrm{WAO}_{4} \mathrm{AWW}$, enz.)

$\mathrm{O}$ ik ben rentenier

$\mathrm{O}$ ik ben gepensioneerd/vervroegd met pensioen (AOW, VUT, enz.)

$\mathrm{O}$ ik ben huisvrouw

4. Wat is uw beroep of functie? Of, als u geen betaalde baan heeft, wat was dan uw laatste beroep of functie? N.B. wilt u uw beroep zo mauwkenrig mogelijik omschrijven? Bijwoorbeeld: directie-secretaresse, metaallasser, hoofd boekhouding (en niet ambtenaar, manager, arbeider enz.) 


\section{Tot Slot.}

1. Als er naar aanleiding van deze vragenlijst nog onduidelijkheden zijn, mogen wij dan meti contact optemen voor nadere informatie?

O nee

O ja, mijn telefoornummer is

2. Hae lang heeft u erover gedaan om de vragenijst in te vullen en heeft u deze vragenljst alleen ingevuld?

$O$ ja ik heb de vragenlijst alleen ingevuld.

O nee ik heb deze vragenlijst met mijn partner ingevuld.

O nee ük heb deze vragenlijst met een derde (bijvoorbeeld met cen tolk) ingevuld.

3. Wat is de reden geweest van uw anmelding voor dit onderzok?

4. Hoe vond u het om deze vragen in te vullen.

Wilt u als u klaar bent controleren of u alles heeft ingevuid.

WU WILLEN U HEEL HARTELIJK BEDANKEN VOOR DE THD EN DE MOEITE DIE U HEEFT GENOMEN OM DE VRAGEN TE BEANTWOORDEN.

Mocht u nog op- of aanmerkingen hebben, dan zouden wij het zeer op prijs stellen als u dat zou willen opschrijven.

Met vriendelijke groeten,

Diagnostisch Centrum Eindhoven. 
Patient Identificatie

pattient nummer
Screwningsidatum

datum (dd/mm/lis)

\section{A. Patiènten identificatie/administratie}

1. Wat is uw geboortedatum?

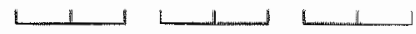

2. Wat is uw postcode en hus nummer?

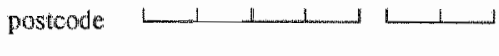

huisnummer

3. Wat is uw telefoonnummer warop a overdag bereikbar bent?

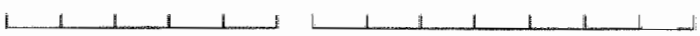

4. Wie is uw buisarts en in welke plats heeft uw huisarts zijn praktik?

5. Bent u nomenteel onder controle bij uw huisarts of bij een specialist?

O nee

O ja, voor

6. Denkt un er over binnenkort ve verthuizen?

O nee, ga naar vraag 8

O ja

7. Indien uw nieuwe adres al bekend is wilt u oit dan hieronder opschrijven. fndien dit nog nier bekend is wilt u ons dan een adreswijziging toesturen?

naam:

adres:

woonplaats

telefoommintrier

\section{B. Menstruatie anamnese}

8. Heeft u ooll de (prik)pil gebruik?

O nee, ga natr wragag 11 .

O ja, gebruik ik nog steeths, ga naar vraag 10 .

O ja, maar gebruik ik al > 3 jar nief mer.

$\mathrm{O} j a$, maar gebruik $i k$ all $<3$ maanden niet meer.

O ja, maar gebruik ik al 3 maanden to 3 jaar niet meer. 
9. Wanter bent is gestopt met de pil (matal + jaar)?

19 marand.

10. Deze yrapas altid steilen:

Watarom gebruikt(e) u de pil (nog) en hoe lang gebruikt(e) a de pil al?

11. Hetf u ooit oestrogempleisters/andere wrowwelijke hormoompreparaten (overgangspil) gebruilkt? O wex, ga mar vraag 14.

O ja, gebruk ik nog stews, ga nar viag 13.

O ja, makr gebruik ik al $>3$ jar niet meer, ga naar wrage 12.

$\mathrm{O}$ ja, mat gebrulk iK al $<3$ mataden net meer, ga nar wragg 12 .

O ja, marr gebruil ik al 3 manden tot 3 jar niet meer, ga naar vraag 12

O weet ik niet

12. Wanneer bent gesitopt met het gebrulk wan oestrogeenpleisters of andere vrouwelinke hormoonpreparaten (owergangspil) (maand + jaar)? 19 mand

13. Warom, gebrukt(e) u deze oeswogeenpleisters/ andere vrouwelijke hormoonpreparaten (overganggpil) en lhoe lang?

14. Hoe oud was ut toen $u$ woor het eerst menstrueerde?

.................... jedar

15. Menstruest a nog?

O nllee

$\mathrm{O}$ ja

16. Hoe wak bent u de laatste 12 maanden ongesteld geweest?

$\mathrm{O}$ niet

O een keer

O wier keer

0 wwe ker

$O$ wijf keer

O drie keer

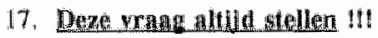

Hoe latig is het geleden dat u ww ladste natudilike menstruatie liad? (niet meetellen als de menstruatie werd weroomakt door het innemen van wrouwelyjk homoonpreparaten, overgangspil, anticonceptiopil), Graag maand en jaar invullen.

methatid: 19

$0<1$ mand geteden

O 1 tot 3 manden geleden

O 3 tot 6 manden geleden

O 6 matanden tot 1 jar geleden

$0>1$ jagr gehaten

$0>2$ jan geloden. ga natr wrata 23

$0>3$ joar geleden, ga naar wrag 23 


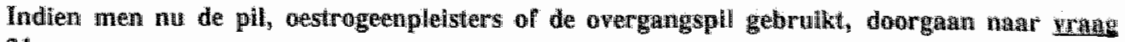
21.

18. Is de regelmaat wan uw menstruate de lagtste jaren varanderd (nuand + jaar)?

O thee

O ja, sinds ......... $19, \ldots \ldots$.

$O$ is altijd al onegelmatig geweest

19. Om de hoverell dagen wordt u ongesteld? dagen

20. Hoeveel dagen verliest a bloed tijdens de menstruatie? dagen

21. Hoe schat u de hoeveetheid bloedverlies in tijdens de menstruatie?

O weinig

O normal

Or weel

22. Is uw hoeveetheid bloedverlies tijdens de laatste 12 maanden veranderd?

Onee

O ja, minder geworden

O ja, meer geworden

$\mathrm{O}$ ja, afwisselend

23. Is uw baarmoeder verwijderd $\mathrm{d}_{\text {, }} \mathrm{ja}$, wanneer is dit gebeurd (maand - jaar)?

O nee

O ja, 19

24. Is er ooil een eierstok bij $\mathrm{u}$ verwijdend?

O nee, ga naar vratag 27.

O ja, tên

O ja, beide

O weet ik niet

25. Warneer is uw eierstok werwijderd (maand en jaar invullen)?

De eerst:

................. 19

De tweede:

19

26. Menstruedre u nog steeds na deze operdict

0 nee

0 ja

0 weet in miet

27. Hoeveel eigen kinderen heeft $u$ in total? ...... kinderen. 
28. Hoe wak bent a zwanger geweest? Hiermee bedoelen wij ook we wroeg afgebrokem zwangergehappen. zwangerschappen. Indien t nooit zwanger bent gewwest door naar varag 32 .

29. In welk jaar werd uw eergte chi laatste kind geboren?

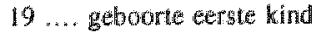

19.... geboorte latats kind

30. Heeft wh kinderen borstvoeding gegeven?

O nee, mat vraag 32

O ja, gemidideld

31. Hoveel kinderion gaft u borstwoeding? kinderen

32. Heft ww arts u oolt wel sevs verteld dat u een afwijking aan de schildklier heeft (gelhad) en bemt u hierwoor rogig stezis in behandeling?

O nees

O jlat, te snel werkend

O ja, te trang werkend

$\mathrm{O}$ wergrote schildiklier

O weat ik nider

33. Komen sr in un familie schildklierzlekten voor?

O neat

$\mathrm{O}$ ja, bij uw

O wext ik miet

34. Hewt thw ants u opit wel eens verteld dat a een kwadaardige aandoening heeft (gehad), zo ja war?

Onese

O ja namelijk

0 weet ik niet 


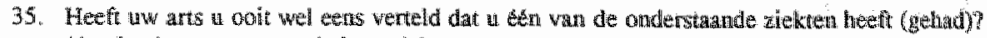
(Aankruisen wat voor iederte ziekte apart van toepassing is en op de stippellin inwullen weike zitekto

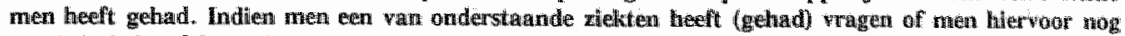
steeds in behandeling is).

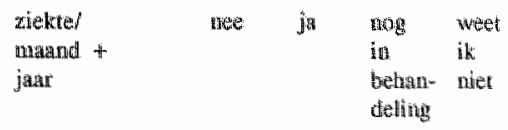

- Revma (reurnatoinde arthritis)

$0 \quad 0 \quad 0$

- slijtage van de gewrichten (arthrose)

- andere ziekte wastroor u moeilijk kunt bewegen?

- Eed trombasebeen?

- De ziekte van Cushing?

- Een longembolie?.

- Een botziekre, by de ziekre van

Paget. osteoporose. Engelse ziekte?

- Een hartinfarct?

- Een beroertel antaque?

- Hoge bloeddruk?

- Een nieraandoening/ afwijking van de nheren?

- Een ziekre van de bijnieren?.

- Een ziekie van de bijschildikhier?

- Eent lewerziekte, (bv hepatitis, geelzuchi of exn leverontstekingy.

- Suikerziekte.

- Een stofwisselingszielkte? O

- Een aandoening van het spijswertering skandaal:

- Zwweertjes in de slokdaron

- Een zweer van de twallfingerige darn.

- Ziekte van Crohn.

- Een majagweer, ontsioken madagshijnwlies of een operatie.

- Colitis ulcerrosa.

- Andere.

36. Bent u ooit langer dan 1 maand bedlegerig geweest?

O mase

O ja

O weet ik miet 
De volgends wagen gar over dringewoonten.

37. Drink we wens alcotol?

$O$ mae noolt. ga natr wrage 40

O ja, elke daig

O ja, $5-6$ dagen per wetk

O ja, 3-4 dagen per week

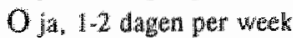

O ja, minder dan edn mal per week

38. Alg u dar dririkt hoeveel gtaxen alcohol drinkt u dan gemiddeld per dag? gidon per dag.

De volgende wragen garn over medlujngebruik.

39. Heeft w het laatste jaar geneesmiddelen tegen botontkalking (osteoporose) gebruikt? 20 ja, welke?

O nee

O jain

O weet ik niet

40. Heaf u het latutc jar cen van de volgende geneesmiddelen gebruikt?

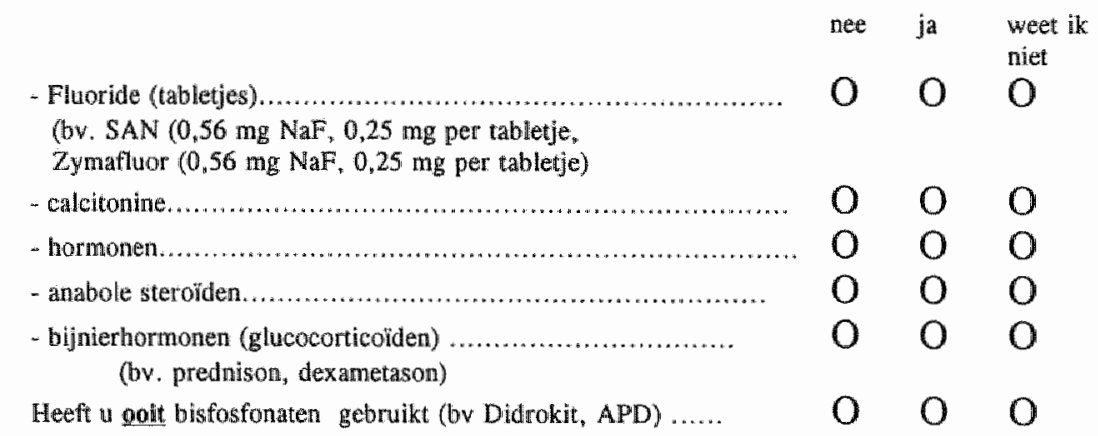

41. Indien u medicijnen gebruikt welke medicijnen zijn dit?

42. Vindt u het goed als uw huisarts de uitslag van de botmeting krijgt?

Onee

O jat 
43. Vindt u het goed diat we indien nodig bij uw huisarts informeren naar medische gegevens, die mogelijk betrekling hebben op dit onderzoek?
Onee
$\mathrm{O}$ jia

44. Als blijkt dat er sprake is wan enige afwijkingen of klachten, mogen we u dan benaderem om ann een vervolgonderzok mee te doen.

O nee

O ja

45. Mogen wij $u$, ook als er nu geen afwijkingen gevonden zijn, in de toekomst nogmaals uitnodigen voor een vervolg onderzoek?

$\mathrm{O}$ nee

$\mathrm{O}$ ja

46. Als er naar aanleiding van deze vragenlijst nog onduidelijkheden zijn, mogen wij dan met u contact opnemen voor nadere informatie?

$\mathrm{O}$ nee

$\mathrm{O}$ ja, dit kan het beste onder telefoonnummer:

\section{Medisch onderzoek}

1. bloeddruk sys.

2. bloeddruk dia.

3. pols

4. gewicht

5. lengte

6. Quetelet-index (gewichth/lengte ${ }^{2}$ )

7. spanwijdte van de armen

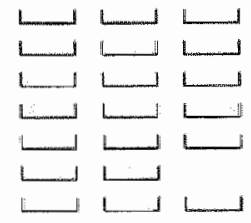




\section{Dankwoord}

Het moment waarop mij de vraag werd gesteld of ik interesse had te starten met een promatieonderzoek was na afloop van een hockeywedstrijd met het Artsen Team Eindhoven en Omstreken (ATEO). Een collega en medespeler vond mijn strijdlust en gedrevenheid in het veld voldoende aanleiding om mil die vraag voor te leggen.

Na een periode van twijfel over met name mijn onmisbaarheid in de praktijk en na uitgebreid overleg met het thuisfront besloot ik schoorvoetend me op het volstrekt onbekende pad van wetenschappelijk onderzoek te begeven.

Op dit pad ontmoette ik nogal wat mensen die mij ieder op hun eigen wijze tot steun waren bij het bereiken van het doel dat gedurende de periode van 1994 tot heden langzaam maar zeker duidelijke vormen aannam en uitmondde in mijn promotie.

De eerste persoon op het pad is de collega en medespeler uit het hockeyteam, mijn promotor Professor V.J.M. Pop. Beste Victor, door jouw bizarre manier van stimuleren, je vaardigheid met SPSS, je onvcorwaardelijke inzet en de goede wijn in je studeerkamer, ben ik tot afronding van dit proefschrift gekomen. Ik ben zeer dankbaar onder jouw professorale hoede te kunnen promoveren. In Eindhoven vonden alle activiteiten met betrekking tot mijn onderzoek plaats op het Diagnostisch Centrum Eindhoven (DCE). Aan het roer van deze organisatie staat mijn co-promotor Dr J.J. Keyzer. Beste Jules, in jouw centrum en onder jouw leiding werd de EPOS studie "binnengehaald" en kon ik ongestoord en in alle vrijheid werken. Je deur stond en staat letterlijk en figuurlijk altijd open. Bedankt voor je steun en adviezen. De relatie met de geneeskundige faculteit in Maastricht werd gelegd door mijn promotor Prof. J.A. Knottnerus. Beste André, als geen ander spelde je mijn teksten na, scherpte je de epidemiologische nuances en liet je je door mij maandelijks onderscheppen op het station van Eindhoven op je reizen van Maastricht maar Den Haag vice versa. Dankzij jouw positieve instelling was elke bijeenkomst een voortdurende stimulans. Het onderzoek in het DCE werd gedurende de jaren gedragen door een hecht team van medewerkers. In de beginperiodle had ik veel steun aan Cecile Smeets en Ineke Roothans. Mijn voortdurende steun en toeverlaat was Simone Sanders, later bijgestaan door Annelies van Gool. Geraline Leusink trok op doortastende manier de EPOS kar over alle hobbels en obstakels en zorgde voor een voorbeeldige database. Vele medewerkers van het DCE hebben mij daarnaast meegehalpen om in een prettige sfeer mijn onderzoek te kunnen doen. In de laatste fase was Colette Wijnands een geweldige hulp in de bewerking van alle teksten voor het manuscript. Om de puntjes op de Engelse i te zetten maakte ik gebruik van de enthousiaste hulp van Gay Wylie en Marion Olivier. 
In mijn praktik moest op de dagen dat ik awwezig was ook gewerkt worden. In de loop van de jaren hebben Jos Dijkmans en later Cateleyne Venteville beiden op geheel eigen wijze invulling gegeven aan hun waarneemtaak. Dankzij hen had ik nooit het gevoel onmisbaar te zijn. De assistentes moesten zich regelmatig in bochten wringen om al het "osteoporose-geveld" dat in de loop der jaren per fax, telefoon of als camerateam op hen afkwam, het hootd te bieden. Annie Bouw. Kitty Willems en Cecile Smetsers hielden het hoof d koel en het roer recht. Meiden bedankt voor jullie geduld en hulp. Als onvoorwaardelike steun in de praktijk was er altijd mijn collega Paul Schaffer. Nooit hoefde hij te weten hoe ver ik al was en of ik opschoot. Altid kon ik op hem rekenen als er weer een dienst te ruilen was of een uurtje achterwacht. Paul je bent een gouden maat. Uiteraard was het verkrijgen van alle gegevens via de vragenlijsten van het EPOS onderzoek nooit mogelijk geweest zonder de wewillende medewerking van ongeveer tienduizend perimenopauzale Eindhovense dames. Onvoorstelbaar met welke openheid deze vrouwen de meest diverse soorten uragen hebben willen beantwoorden.

Tot slot het zenuwcentrum waar het allemaal gebeurde: Huize Maartens. Lieve Imke, Thijs, Lisanne en Jolijn. Waarom moest ik in deze fase van jullie leven me bezig gaan houden met een ultieme egotrip? Ik kan jullie daar geen duidelik antwoord op geven, ook niet op de vraag wat ik er uiteindelik mee bereik. Gelukkig zag ik jullie zowel met studie als met sport je talenten gebruiken. Blijf zo doorgaan. Tenslotte miln lieve Jolande; zonder jou was dit nooit gelukt. 


\section{Curriculum Vitae}

Luc Maartens werd geboren te Eindhoven op 3 september 1955 als tweede van een 2-eilge tweeling. In 1972 behaalde hil het diploma HBS-B aan het Lyceum Augustinianum. Ten gevolge van de numerus clausus werd hij een jaar uitgeloot en volgde een jaar de opleiding tot medisch analist aan het $\mathrm{HBO}$ te Eindhoven. In 1973 begon hij met de studie Geneeskunde aan de Katholieke Universiteit Nilimegen. In 1979 deed hij zijn doctoraal examen en in februari 1982 werd het artsexamen behaald.Vervolgens startte hij zijn huisartsenopleiding vanuit het Nijmeegs Universitair Huisartsen Instituut en werd opgeleid door Jaap 5tolte in het gezondheidscentrum "de Schelp" te Swifterbant (Oostelijk Flewoland).

Direct daarop aansluitend moest hij zijn dienstplicht vervullen als luitenantarts bij de Militair Geneeskundige Dienst en werd te werk gesteld in Roermond en Rheindalen (Duitsland).

Op 1 Januari 1984 startte hij als huisarts in Eindhoven.

Van 1985 tot 1992 was hij verbonden aan het Sport Medisch Adviescentrum te Eindhoven. In 1993 verhuisde zijn praktijk naar het Huisartsencentrum Parklaan waar hij een HOED (Huisartsen Onder Een Dak) vormt met Paul Schaffer.

In 1994 begon hij anderhalve dag per week als huisartsonderzoeker bij het Diagnostisch Centrum Eindhoven in het kader van het EPOS project en vanaf 1998 in het kader van het EDIS project. In 1996 nam hij zitting in de Wetenschappelijke Raad van de Osteoporose Stichting en in 2000 werd hij redactielid van het Nederlands Tijdschrift voor Osteoporose en andere Botziekten.

Als consulent of huisartsvoorzitter was hij vanaf 1995 veelvuldig verbonden aan cursussen, nascholingsbijeenkomsten en congressen in binnen- en buitenland.

Luc is getrouwd met Jolande van der Put, samen hebben zij vier gezonde kinderen: Imke, Thijs, Lisanne en Lolijn. 